\author{
UNIVERSIDADE DE SÃO PAULO \\ INSTITUTO DE FÍSICA DE SÃO CARLOS \\ INSTITUTO DE QUIMICA DE SÃO CARLOS \\ ESCOLA DE ENGENHARIA DE SÃO CARLOS
}

REGINA ESTEVAM ALVES

Caracterização de fibras lignocelulósicas pré-tratadas por meio de técnicas espectroscópicas e microscópicas ópticas de alta resolução 



\section{Caracterização de fibras lignocelulósicas pré-tratadas por meio de técnicas espectroscópicas e microscópicas ópticas de alta resolução}

Dissertação apresentada ao Programa de Pós-Graduação em Ciência e Engenharia de Materiais, da Universidade de São Paulo, para obtenção do título de mestre em Ciência e Engenharia de Materiais.

Área de concentração: Desenvolvimento, Caracterização e Aplicação de Materiais. Orientador: Prof. Dr. Francisco Eduardo Gontijo Guimarães 
AUTORIZO A REPRODUÇÃO E DIVULGAÇÃO TOTAL OU PARCIAL DESTE TRABALHO, POR QUALQUER MEIO CONVENCIONAL OU ELETRÔNICO, PARA FINS DE ESTUDO E PESQUISA, DESDE QUE CITADA A FONTE.

Ficha catalográfica preparada pela Seção de Tratamento da Informação do Serviço de Biblioteca - EESC/USP

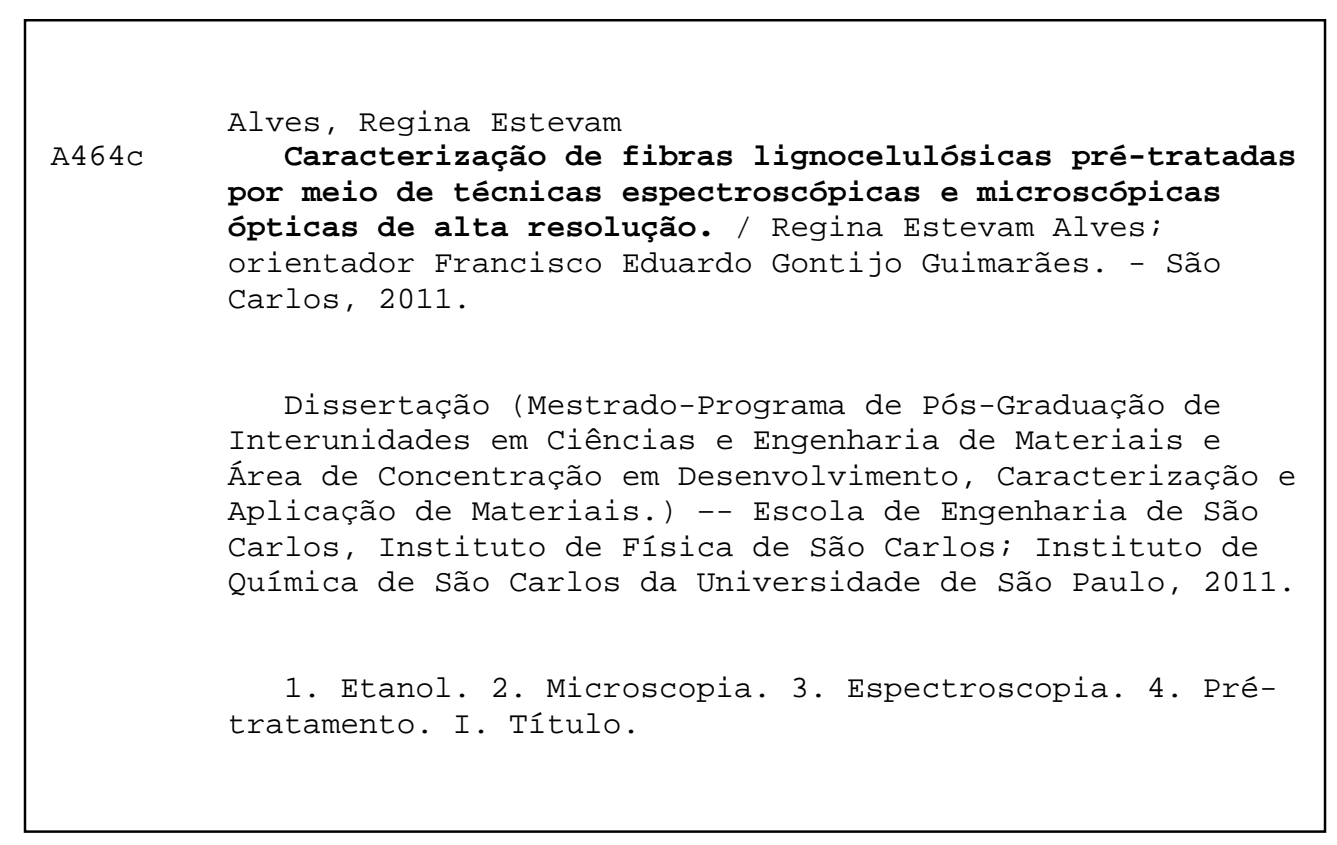


FOLHA DE APROVAÇÃO 

Dedico este trabalho a Deus, em quem eu sempre confio e a minha família: minha mãe Luzia, meus irmãos (Régia, Regiane e Reginaldo) pelo amor, apoio e incentivo que me foi concedido; e meu pai Reinaldo (em memória) que se foi muito cedo, não tendo tempo para participar desta etapa da minha vida. 



\section{AGRADECIMENTOS}

- A Deus, por ter me guiado, me protegido, me dado força, sabedoria e saúde para concluir mais uma das etapas da minha vida.

- A minha mãe, Luzia, por ter me alfabetizado e pelas inúmeras vezes que me ajudou com tarefas nos primeiros anos de vida escolar, sendo fundamental para que eu prosseguisse nos estudos e chegasse até aqui. Ela é minha fonte de forças nas horas de dificuldades e sem dúvidas, todo amor, carinho e dedicação que me concedestes, eu certamente jamais irei conseguir retribuí-la.

- Ao meu pai (em memória), cujas lembranças nas horas de dificuldades foram essenciais para que eu conseguisse enfrentar de forma equilibrada todos os "obstáculos" apresentados no decorrer do desenvolvimento deste trabalho.

- Aos meus irmãos: a Régia que não mediu esforços para me ajudar nos primeiros meses de vida em São Carlos; a Regiane por me ensinar a ser forte e não ter medo de lutar pelos meus objetivos, e ao Reginaldo por dizer que sou o seu orgulho. Amo todos eles e agradeço pelo apoio, incentivo, confiança e principalmente, por constantemente me cercarem de carinho, amor $\mathrm{e}$ compreensão.

- Aos amigos Alexandre Marciel, Rodrigo Silva, Vanaleia Geraldo, Analine Ziglio, Adriana Pavinatto e Adriano Otuka, os quais gentilmente me ajudaram com a finalização deste trabalho. Sem eles, certamente eu não teria conseguido.

- A prof ${ }^{a}$. Lauralice, pelo "colo de mãe" e por possibilitar a finalização deste trabalho.

- Ao professor Máximo Siu Li e Marcelo Henrique Gehlen pela ajuda com interpretações de resultados, correções e incentivo.

- Ao Prof. Antônio Ricardo Zanatta, pelas medidas de FTIR, ajuda com interpretação dos resultados e correção dessa parte na dissertação.

- Ao Prof. Eduardo Ribeiro de Azevêdo, pelas medidas de RMN, ajuda com interpretação dos resultados e correção dessa parte na dissertação.

- Ao Prof. Tito José Bonagamba e seu aluno Marcel, pelas medidas de T2 por níveis de saturação em fibras de eucaliptos.

- Ao Grupo de Cristalografia, especificamente ao Prof. Igor Polikarpov pelo fornecimento das amostras.

- A empresa Aracruz Celulose pelo fornecimento de amostras de eucalipto utilizadas neste trabalho.

- Ao Grupo de Materiais Macromoleculares e Fibras lignocelulósica, em especial a Franciéli Oliveira pelo fornecimento de amostras. 
- A Débora Balogh que sempre se mostrou disposta a me ajudar tanto com materiais para revisão bibliográfica como para esclarecimentos de dúvidas. Sou eternamente grata a ela por sua gentileza e paciência.

- Aos técnicos do Grupo de Polímero e Semicondutor: Níbio, Bruno, Aroldo e Carlos pela ajuda.

- Ao pessoal do grupo: Tsutae, Danilo, Fernando, Gustavo, Luis, Ângelo, Nirton, Haroldo e Mike pelos momentos de descontração.

- Aos colegas de sala Victor Rivera, Fábio Ferri, Otávio e Sergio Osório por me animarem nos momentos de desânimo, principalmente, pelos conselhos que me fizeram seguir em frente.

- As minhas amigas Lioneida Mendes, Daiana Mishimishi e Gisele Cabral as quais mesmo morando muito longe, se fizeram presente durante mais uma etapa importante da minha vida. Obrigada pelas constantes preocupações, ajuda, apoio, torcida, conselhos e carinho.

- Aos amigos do IFSC OSA Student Chapter pelos momentos de bolachinha com coca-cola regados com boas risadas.

- Ao Prof. Tomaz Catunda e a Prof a . Glaúcia por me convencerem a fazer o mestrado no IFSC, principalmente, por me receberem e me ajudarem nos primeiros meses de moradia em São Carlos.

- Ao pessoal da biblioteca do IFSC e da EESC pela ajuda com as correções da escrita e formatação.

- Ao Ítalo e suas companheiras na gráfica do IFSC pelos serviços prestados durante os anos de mestrado.

- A secretaria do IFSC e da Interunidade, em especial ao Sílvio, Victor, Sirlene e Samira pela ajuda com a parte burocrática.

- A Capes pela bolsa concedida durante os anos de mestrado.

- A tia Clara Helena e ao tio Luís pelos cuidados e dedicação prestados durante parte da minha vida, contribuído também, de certa forma, para que eu chegasse até aqui.

- Ao Prof. Francisco Eduardo Gontijo Guimarães pela orientação.

- Ao longo dos anos do mestrado, tive a felicidade de contar com muitas pessoas que me apoiaram em todas as circunstâncias. Não posso citar todas e seria horrível esquecer uma delas, mas vocês sabem quem são. Obrigado por fazerem parte da minha vida, tornarem meus dias mais alegres e me ajudarem a seguir em frente. 
A ciência nos ensina a perseguir sonhos aparentemente impossíveis. Hoje acredito que o impossível é somente o possível que alguém ainda não teve tempo suficiente para tornar realidade. Basta ter um sonho que verdadeiramente seja a razão de nossas vidas.

Miguel Nicolelis 



\section{RESUMO}

Alves, R. E. Caracterização de fibras lignocelulósicas pré-tratadas por meio de técnicas espectroscópicas e microscópicas ópticas de alta resolução. 2011. 115p. Dissertação (Mestrado) - Instituto de Física de São Carlos, Instituto de Química de São Carlos e Escola de Engenharia de São Carlos, Universidade de São Paulo, São Paulo, 2011.

Neste trabalho, fibras de eucalipto pré-tratadas diferentemente com ácido e/ou enzima foram investigadas visando se verificar alterações estruturais decorrentes dos prétratamentos. Na caracterização foram empregadas técnicas de microscopia eletrônica, de fluorescência (campo de claro), de fluorescência confocal de varredura a laser (CLSM) e de tempo de vida de imagem de fluorescência (FLIM). Além disso, foi também empregada espectrocopia de fluorescência, absorção no ultravioleta e vísivel (UV-Vis), no infravermelho (FT-IR) e ressonância magnética nuclear (RMN). Para a caracterização das fibras via microscopia e espectroscopia de fluorescência foi necessário a produção de filmes de fibras de eucalipto. Os resultados demonstraram um aumento na intensidade da fluorescência das fibras em função dos pré-tratamentos. As imagens de microscopia permitiram conhecer a estrutura morfológica das fibras. Para aumentar a fluorescência das fibras e facilitar a visualização por microscopia de fluorescência, nós depositamos o polieletrólito poli(cloreto de tetraidrotiofeno de xililideno) (PTHT), precursor do poli( $p$-fenileno vinileno) (PPV). Pelas imagens CLSM observou-se a afinidade do PTHT-PPV pelas as fibras que, foi investigada pelo método arraste. A distribuição de tempos de vida associado à imagem FLIM da fibra de eucalipto indicou a presença do PTHT-PPV nas superfícies da fibra e a lignina no interior da parede da mesma. O PTHT-PPV apresentou um tempo de decaimento de fluorescência mais curto do que a lignina. As análises composicionais das fibras de eucalipto e do bagaço de cana-de-açúcar in natura evidenciaram sinais relacionados à lignina, hemicelulose e celulose.

Palavras chave: Etanol, Microscopia, Espectroscopia, Pré-tratamento. 



\begin{abstract}
Alves, R. E. Caracterização de fibras lignocelulósicas pré-tratadas por meio de técnicas espectroscópicas e microscópicas ópticas de alta resolução. 2011. 115p. Dissertação (Mestrado) - Instituto de Física de São Carlos, Instituto de Química de São Carlos e Escola de Engenharia de São Carlos, Universidade de São Paulo, São Paulo, 2011.
\end{abstract}

In this dissertation, eucalyptus fibers pretreated with different acid and / or enzyme were investigated in order to study the resulting structural changes of the fibers. The characterization was made using several microscopy techniques such as, electronic microscopy, confocal laser scanning microscopy (CLSM) and fluorescence lifetime imaging microscopy (FLIM). In addition, we used fluorescence spectroscopy, absorption in the ultraviolet and visible (UV-Vis), infrared spectroscopy (FT-IR) and nuclear magnetic resonance (NMR). It was necessary to produce films of eucalyptus fibers for the characterization of fibers via microscopy and fluorescence spectroscopy. The results showed changes in the fluorescence intensity of the fibers as function of the pre-treatments. The microscopy images were used to study the morphological structure of fibers. To increase the fluorescence of the fibers and facilitate its visualization via fluorescence microscopy, e deposited a polyelectrolyte precursor of PPV poly( $p$-phenylenevinylene), the poly-(xylylidenetetrahydrothiophenium chloride). CLSM images revealed an affinity between the PTHT-PPV and the fibers. This affinity was investigated by a method consisting of spinning a solution containing the fibers and subsequent optical analysis. The results confirmed the affinity of PTHT-PPV with eucalyptus fibers. The lifetime distribution associated with the FLIM image of eucalyptus fiber indicated the presence of PTHT-PPV on the fiber surface and lignin in the inner wall of the fibers. Also, the PTHT-PPV showed fluorescence decay time shorter than the lignin. The analysis of the composition of eucalyptus fibers, we used sugar cane bagasse in natura to facilitate the identification of functional groups. The results showed signs related to lignin, cellulose and hemicellulose.

Key-words: Ethanol, Microscopy, Spectroscopy, Pretreatment. 



\section{Lista de Figuras}

Figura 1- Consumo de energia global para o ano de 2008. Outros: inclui energia geotérmica, solar, vento, calor, etc. (International Energy Agency, 2010).

Figura 2 - Esquema mostrando as etapas do processo de bioconversão de açucares em bioetanol (ESTEVAM-ALVES; GUIMARÃES, 2009; Greentechmedia, 2010; U.S. Department of Energy Genomic Science program, 2010; How stuff works a discovery company: SUGARCANE, 2010).

Figura 3 - Representação esquemática da estrutura de células vegetais de cultura de bioetanol mostrando a membrana plasmática, lamela média, a parede celular e os principais componentes da parede celular (lignina, hemicelulose, celulose, pectina e proteínas) (How stuff works a discovery company: SUGARCANE, 2010; Human Genome Project, 2010; SELEGHIM JR; POLIKARPOV, 2009; STICKLEN, 2008). . 28

Figura 4 - (a) Rede de microfibrilas de celulose contendo regiões cristalinas intercaladas por regiões amorfas e (b) estrutura molecular parcial da hemicelulose tendo como unidades repetitivas o monômero de glicose e o dímero de glicose que é a unidadade de celobiose (COTTON INCORPORATED, 2011) ................................... 30

Figura 5 - Estrutura molecular parcial da hemicelulose. .............................................. 31

Figura 6 - Representações de unidades de polissacarídeos presentes na hemicelulose: (1) $\beta$-D-Xylose, (2) $\alpha$-L-Arabinopyranose, (3) $\alpha$-L-Arabinoforanose, (4) $\beta$-D-Gluocose, (5) $\beta$-D-Manose, (6) $\alpha$-D-Galactose, (7) $\beta$-D-Ácido Glucuronico, (8), $\alpha$-D-4-0-Ácido methylglucuronic (9) $\alpha$-D-Ácido galactose, (10) $\alpha$-L-Ramnose e (11) $\alpha$-L-Fucose (FENGEL; LIN, 1984; MAREBEZI, 2009; NASCIMENTO; SILVA, 2002; PASTORE, 2004).

Figura 7 - Precusores primários da lignina: a) álcool trans-p-cumarílico; b) álcool transconiferílico e c) álcool trans-sinapílico (BALOGH, 1989).

Figura 8 - Principais unidades aromáticas presente na molécula de lignina: (a) phidroxifenila; (b) Guaiacila; (c) Siringila (SANTOS, 2001)........................................ 33

Figura 9 - Estrutura parcial hipotética de lignina (FENGEL; WEGENER, 1984)......... 34

Figura 10 - Possíveis sítios reativos das unidades da lignina (BOTARO, 1996)......... 35

Figura 11 - Esquema das transformações que sofre a biomassa lignocelulósica durante o pré-tratamento (ESTEVAM-ALVES; GUIMARÃES, 2009; MOSIER et al., 2005).... 36

Figura 12 - Conversão de grupos $\alpha$-éter para íons carbônio e oxônio, respectivamente

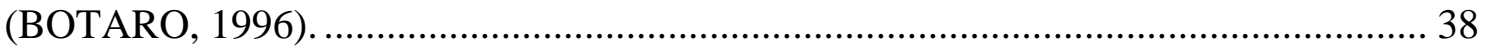

Figura 13 - Reações de unidades de lignina em ácido sulfúrico (MARABEZI, 2009).. 39

Figura 14 - Amostras de fibras lignocelulósicas empregadas neste trabalho: (a) oriundas de eucalipto; (b) oriundas de bagaço de cana-de-açúcar in natura (BCA) (na forma bruta, ou seja, sem qualquer pré-tratamento).

Figura 15- Representação esquemática da sequência dos pré-tratamentos aplicados às fibras lignocelulósicas de eucalipto pela empresa Aracruz Celulose, tomando como padrão de referência neste trabalho a amostra de fibra não tratada com ácido e/ou xilanase.

Figura 16 - (a) Amostra de lignina de eucalipto na forma de pó; (b) solução de lignina a 0,05 mg.mL-1 pH 9 e (c) solução, esta última a 0,002 mg.mL-1 pH 9. 44 
Figura 17 - Representação da estrutura química do polímero PTHT-PPV: a) Unidade repetitiva do PPV; b) Unidade repetitiva do PTHT (MAIA, 2006). 45

Figura 18 - Diagrama referente à absorção luminosa segundo a lei de Lambert-Beer (INSTITUTE OF PHYSICAL CHEMISTRY, 2009). 46

Figura 19 - Espectro de absorção na região UV da lignina de eucalipto (ALESSIO et al., 2008). 48

Figura 20 - Espectros de absorção na região UV do copolímero PTHT-PPV (FACETO, 2007).

Figura 21 - Diagrama de Jabloski. Caminhos para a dissipação de energia de um estado excitado.

Figura 22 - Espectros de uma amostra de eucalipto: (A) excitação, com comprimento de máxima emissão em 410 nm; (B) Emissão, com comprimento excitação em $344 \mathrm{~nm}$ (PANDEY; UPRETI; SRINIVASAN, 1998). 53

Figura 23 - Espectro de fluorescência do copolímero PTHT-PPV mostrando a três bandas de emissão (FACETO, 2007). 54

Figura 24 - Filme de fibra lignocelulósica de eucalipto tendo como substrato vidro BK7, destacando (linha pontilhada em vermelho) a região contendo o PTHT-PPV. A mancha em azul trata-se de uma marca feita no lado oposto do substrato para identificação da amostra. 57

Figura 25 - Esquema do microscópio confocal de fluorescência varredura laser, mostrando como o pinhole bloqueia a luz fora de foco (Claxton; Fellers; Davidson, 1979).

Figura 26 - Fluxograma do procedimento experimental do método de arraste aplicado na investigação da interação adsorssiva entre as fibras de eucalipto e o polímero luminescente PTHT-PPV.

Figura 27 - (a) Espectros de excitação com intensidade máxima de emissão $\lambda$ em em 455 nm (à esquerda) e de fluorescência (à direita) com excitação fixado em $370 \mathrm{~nm}$; (b) Distribuição de intensidades de fluorescência para das fibras de eucalipto: não tratada com ácido e/ou xilanase (FENT), tratada com ácido (FETA), tratada com ácido e xilanase (FETAE), tratada com xilanase (FETE) e tratada com xilanase e ácido (FETEA).

Figura 28 - Espectros de lignina mostrando em diferentes pH: (a) absorções e (b) excitação com comprimento de emissão máxima entre 410-433 nm (à esquerda) e fluorescência (à direita) com comprimento de excitação máxima ( $\lambda$ exc) em 320 nm... 67

Figura 29 - Espectros 13C CP/MAS RMN: bagaço de cana-de-açúcar não pré-tratada (BCA), fibra eucalipto não pré-tratada com ácido e/ou xilanase (FENT), fibra de eucalipto tratada com ácido (FETA) e fibra de eucalipto pré-tratada com ácido e xilanase (FETAE).

Figura 30 - Espectros FTIR de: Água; (FETEA) Fibra de eucalipto pré-tratada com enzima e ácido; (FETAE) Fibra de eucalipto pré-tratada com ácido e xilanase; (FETE) Fibra de eucalipto pré-tratada com xilanase; (FETA) Fibra de eucalipto pré-tratada com ácido; (FENT) Fibra de eucalipto não pré-tratada com ácido e/ou xilanase; (BCA) Bagaço de cana de açúcar in natura (sem qualquer pré-tratamento).

Figura 31 - Comparação de absorbância da banda em $1430 \mathrm{~cm}-1$ observada nos espectros de fibras de eucalipto apresentada na Figura 30. 
Figura 32 - Imagens de transmissão de fibra: (a) setas indicando as regiões de estrangulamento empescoçamento na FETA; (b) mostrando superposição das FETA e (d) setas indicando as fibrilas (ou nanofibras) no plano de fundo da imagem das FETA; Imagens de fluorescência: (c) mostrando a soma das intensidades de fluorescência devido à sobreposição de FETEA; (e) FENT; (f) FETA; (g) FETAE; (h) FETE e (i) FETEA.

Figura 33 - Fibras de eucalipto: (a) não pré-tratada com ácido e/ou xilanase mostrando região de estrangulamento ou empescoçamento (FENT); (b) pré-tratada com ácido (FETA) mostrando os orifícios; (c) pré-tratada com ácido e enzima (FETAE) mostrando o desgaste nos orifícios; (d) Pré-tratada com enzima (FETE), mostrando desgaste maior nos orifícios e, (e) pré-tratada com enzima e ácido (FETEA) mostrando o desfibrilamento.

Figura 34 - (a) Imagens CLSM da fibra de eucalipto sem pré-tratamento ácido e/ou enzimático (FENT) mostrando o corte transversal que evidencia que a fibra é oca e tubular; (b) Imagens CLSM da superfície da fibra de eucalipto pré-tratada com ácido e enzima (FETAE) e corte transversal da região de estrangulamento (ou empescoçamento), mostrando que esta região é mais estreita. Escala das imagens $=10$ $\mu \mathrm{m} .82$

Figura 35 - Comparação de espectros de excitação (azul) e emissão (verde) do PTHTPPV, fibra lignocelulósica e lignina mostrando a faixa de observação (barra cinza) via microscopia cofocal de fluorescência varredura laser. Os espectros em azul correspondem à excitação e os espectros em verde a emissão. A linha vermelha pontilhada identifica o comprimento de onda do laser utilizado em nosso trabalho...... 84

Figura 36 - Imagens de fluorescência de fibras de eucalipto (a) sem PTHT-PPV; (b) com PTHT-PPV.

Figura 37 - Imagens de fluorescência de fibras de eucalipto: (a) pré-tratada com xilanase (FETE), mostrando a fluorescência do PTHT-PPV na superfície da fibra; (b) não prétratada com ácido e/ou xilanase (FENT), mostrando detalhes como parede interna e externa, bem como, um corte confocal evidenciando que a fibra é tubular e oca. Escala das imagens $=5 \mu \mathrm{m}$ 86

Figura 38 - Imagens de fluorescência de fibras de eucalipto pré-tratada com enzima (FETE) mostrando: (a) a fluorescência do PTHT-PPV na superfície da fibra; (b) detalhes como buracos na superfície da fibra. Escala das imagens $=5 \mu \mathrm{m}$. Detalhes da imagem de MEV-FEG da fibra é mostrado para comparação.

Figura 39 - Imagens obtidas a partir de diferentes canais no microcopio confocal de fluorescência mostrando a emissão (a) do PTHT-PPV; (b) da lignina e (c) do PTHTPPV e da lignina juntos. Escala das imagens $=10 \mu \mathrm{m}$ 88

Figura 40 - Fibra de eucalipto: a) que não recebeu nenhum tipo de pré-tratamento (FENT), mas imersa em PTHT-PPV; b) que recebeu pré-tratamento com ácido em seguida com xilanase (FETAE), com o PTHT-PPV e c) que recebeu pré-tratamento com ácido em seguida com xilanase (FETAE) sem PTHT-PPV.

Figura 41 - Imagens de microscopia confocal de fluorescência em 3D de fibras de eucalipto (FENT) sem (a) e com (b) o PTHT-PPV. Escala das imagens $=20 \mu \mathrm{m}$........ 91

Figura 42 - Imagens de microscopia confocal de varredura a laser (modo fluorescência) do filme de fibra de eucalipto não pré-tratada com ácido e/ou xilanase (FENT): a) no tempo de 0 segundo; b) entre os tempos de 40-210 segundos e c) após 400 segundos da 
aplicação do PTHT-PPV. As demarcações representadas por círculos coloridos são regiões fibrilares analisadas na Figura 42. Escala das imagens $=20 \mu \mathrm{m}$.

Figura 43 - Imagens de microscopia confocal de varredura a Laser (modo transmissão) do filme de fibra de eucalipto não pré-tratada com ácido e/ou xilanase (FENT): a) no tempo de 0 segundo; b) entre os tempos de 40-210 segundos e c) após 400 segundos da aplicação do PTHT-PPV. As demarcações representadas por círculos coloridos são regiões fibrilares analisadas na Figura 42. Escala das imagens $=20 \mu \mathrm{m}$.

Figura 44 - Gráfico da evolução temporal: (a) da intensidade luminosa das áreas delimitadas na Figura 40, em função do tempo de difusão da solução de PTHT-PPV na fibra e (b) de intensidade da luz transmitida, nas áreas delimitadas na Figura 41, em função do tempo de difusão da solução de PTHT-PPV na fibra. As setas indicam intensidade de luz laminosa e transmitida nos tempos de 40, 210 e 400 segundos da aplicação do PTHT-PPV 95

Figura 45 - Medidas da solução sobrenadante contendo resíduos de PTHT-PPV que não foi adsorvido pelas paredes das fibras lignocelulósicas de eucalipto: (a) absorção e (b) fluorescência em função da massa de fibras.

Figura 46 - Medidas: (a) Intensidade integrada da fluorescência; (b) Proporção de massa de fibras de eucalipto relativo ao ponto de máxima adsorção. 97

Figura 47 - a) Imagem de microscopia confocal mostrando a contribuição da fluorescência do PTHT-PPV na superfície interna e externa das paredes da fibra; b) Imagem FLIM da mesma fibra mostrando os tempos de decaimento de fluorescência de cada espécie (lignina e PTHT-PPV) representados pelo conceito cor; c) curva de decaimento da fluorescência para o PTHT-PPV e da lignina contida na fibra em função do tempo da medida; d) distribuições dos tempos de decaimento da lignina e do PTHTPPV obtidas da resposta da frequência (quantas vezes o sinal foi observado). Escala das imagens $=10 \mu \mathrm{m}$.

Figura 48 - Cromóforos de lignina os quais contribuiem para as emissões em torno de $500 \mathrm{~nm}$ e comprimentos de onda acima: (a) 7-dimetoxiflavona, (b) 8-hidroxi-3,7dimethoxidibenzofuran-1,4-quinona e (c) Desidrodivanilina 100

Figura 49 - Cromóforos de lignina os quais contribuiem para a faixa de emissão entre 300-450 nm de comprimentos de onda: (a) Coniferil álcool, (b) Coniferaldeido, (f) Cinamil alcool, (c) Bifenil (b) Fenilcumarina, (e) Dibenzodioxinae e (d) Estilbeno... 101

Figura 1A - (a) variação do peso por evaporação em relação ao tempo de repouso da amostra de fibra de eucalipto não tratada com ácido e/ou enzima (FENT); (b) Distribuição dos tempos de relaxação transversal para saturações diferentes de fibras de eucalipto não tratada com ácido e/ou enzima (FENT). 115

Figura 2A - (a) variação do peso por evaporação em relação ao tempo de repouso da amostra de fibra de eucalipto tratada com ácido e enzima (FETEA); (b) Distribuição dos tempos de relaxação transversal para saturações diferentes de fibras de eucalipto tratada com ácido e enzima (FETAE). 


\section{Lista de tabelas}

Tabela 1 - Conteúdo de celulose, hemicelulose e lignina em resíduos agrícolas (SUN; CHENG, 2002). .

Tabela 2 - Resumo de vários processos de pré-tratamento de biomassa lignocelulósica (Alvira et al , 2010).

Tabela 3 - Atribuição dos picos aos diferentes carbonos de cada uma das biomoléculas das fibras de eucalipto e bagaço de cana de açúcar..... 70

Tabela 4 - Resumo das bandas de vibrações no infravermelho observadas em fibras de cana de açúcar e eucalipto. 75

Tabela 5 - Espessura da parede de algumas fibras de eucalipto na presença de PTHTPPV. 



\section{Sumário}

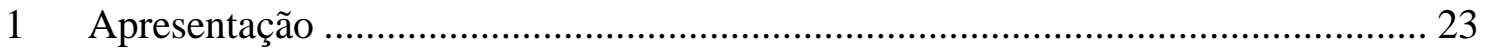

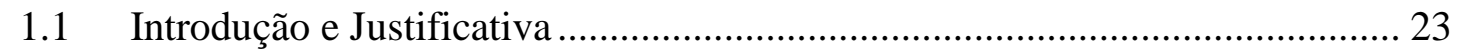

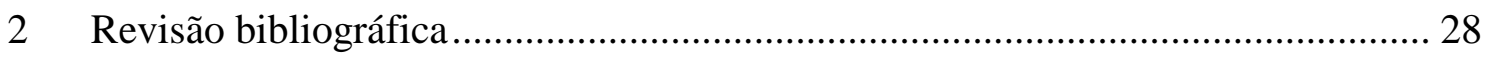

2.1 Biomassa lignocelulósica: estrutura e composição....................................... 28

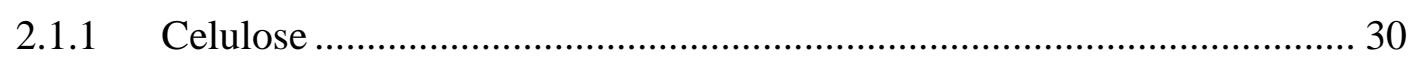

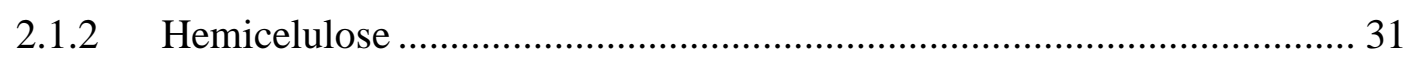

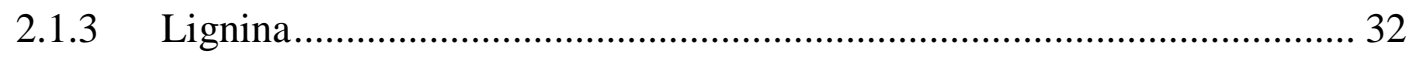

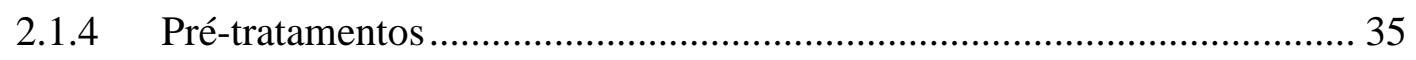

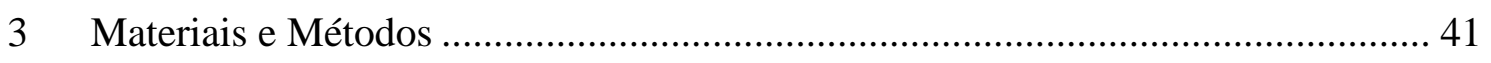

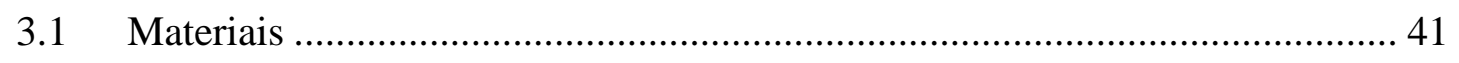

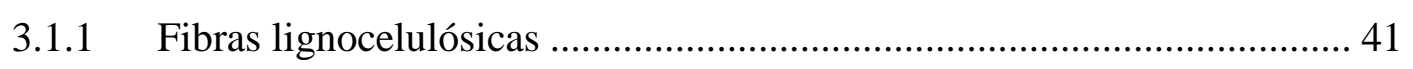

3.1.2 Massa de fibras lignocelulósicas de eucalipto ....................................... 42

3.1.3 Filmes de fibras lignocelulósicas de eucalipto ..................................... 43

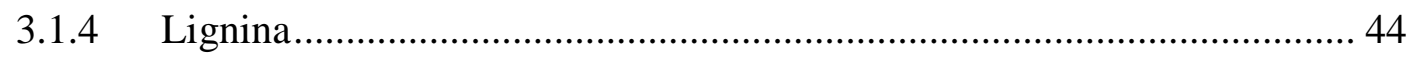

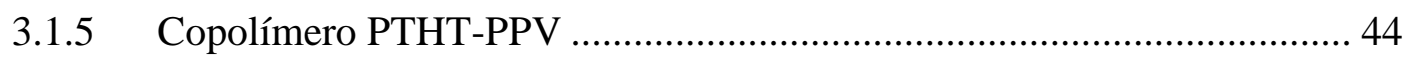

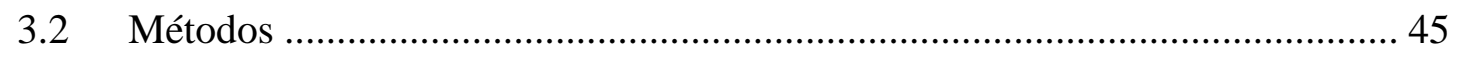

3.2.1 Espectroscopia de Absorção molecular no ultravioleta/visível (UV-Vis) 45

3.2.2 Absorção da lignina ......................................................................... 47

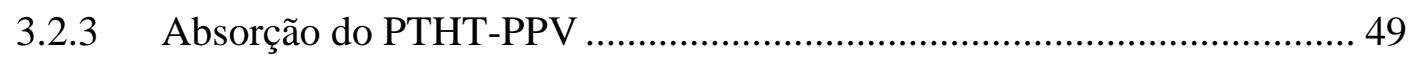

3.2.4 Espectroscopia de fluorescência........................................................... 50

3.2.5 Fluorescência de fibras lignocelulósicas .............................................. 52

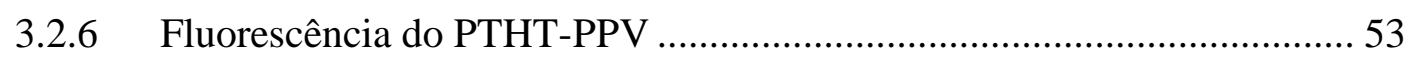

3.2.7 Ressonância Magnética Nuclear.......................................................... 54

3.2.8 Espectroscopia na região do infravermelho......................................... 55

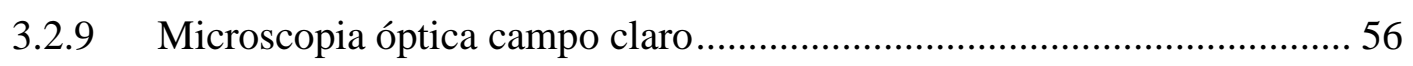

3.2.10 Microscopia eletrônica de varredura por emissão de campo.................... 58

3.2.11 Microscopia de confocal fluorescência varredura laser ........................... 59

3.2.12 Interação e adsorção entre as fibras de eucalipto e o polímero

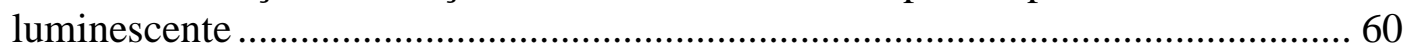

3.2.13 Microscopia de imagem de tempos de vida de fluorescência ................. 63

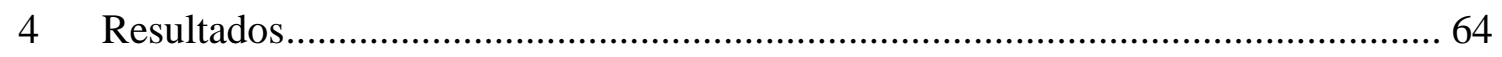

4.1 Caracterização das fibras lignocelulósicas e lignina........................................ 64

4.1.1 Fluorescência das fibras de eucalipto ..................................................... 64

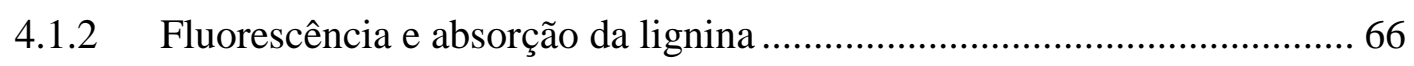


4.1.3 Ressonância Magnética Nuclear........................................................... 68

4.1.4 Espectroscopia no Infravermelho ...................................................... 71

4.1.5 Microscopia óptica campo de claro ..................................................... 76

4.1.6 Microscopia eletrônica de varredura por emissão de campo.................... 79

4.1.7 Microscopia confocal de fluorescência varredura a laser......................... 80

4.1.8 Incorporação de polímero luminescente solúvel em água........................ 83

4.1.9 Difusão e incorporação do polímero luminescente sobre fibras de

4.2 Interação e adsorção das fibras de eucalipto com o polímero luminescente ... 96

4.3 Microscopia de imagem de tempo de vida de fluorescência .......................... 98

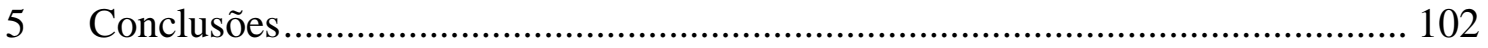

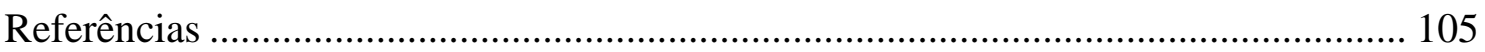

Apêndice A - Medidas de T2 por níveis de saturação em fibras de eucaliptos............. 115 


\section{Apresentação}

Este trabalho está organizado da seguinte forma: no CAPÍTULO 1 destina-se a apresentação, introdução e justificativa do trabalho; CAPÍTULO 2 é apresentado à noção de biomassa lignocelulósicas, sua composição química e estrutural, como também, os vários tipos de pré-tratamentos disponíveis para realização de bioconversão de etanol lignocelulósico; no CAPÍTULO 3 são apresentados os materiais, as técnicas e metodologias aplicadas no decorrer do trabalho; no CAPÍTULO 4 são mostrados os resultados obtidos e suas discussões; e no CAPÍTULO 5, as conclusões. Por fim, são apresentadas as REFERÊNCIAS BIBLIOGRÁFICAS, que serviram de apoio para desenvolvimento deste trabalho e o APÊNDICE A, que apresenta medidas do tempo de relaxação por níveis de saturação em fibras de eucaliptos.

\subsection{Introdução e Justificativa}

A evolução das civilizações tem sido sempre associada, diretamente ou indiretamente, ao uso de energia e, por isso, as fontes de energia foram tratadas no passado como totalmente disponíveis para suprir as necessidades humanas (KAMIDE, 2005). A importância da energia como um elemento fundamental para o desenvolvimento econômico, assim como qualquer estratégia para melhorar a qualidade de vida dos seres humanos e/ou a estabilidade de qualquer país está bem instituída. Contudo, a realidade mostra que a disponibilidade de energia oriunda de fontes não-renováveis é limitada e a exploração, transformação e o uso dessa energia podem gerar sérios impactos no meio ambiente (DEMIRBAS, 2010).

As fontes de energia podem ser classificadas em três grupos: fóssil, físsil e renovável. O termo fóssil se refere a uma era geológica passada, logo, os combustíveis fósseis, formados há milhares de anos atrás não são renováveis (DEMIRBAS, 2008). Os recursos de energia fósseis são o petróleo (petróleo bruto), carvão, betume, gás natural, óleo de xisto e areias betuminosas. Já o termo físsil se refere aos materiais que conseguem 
sustentar uma reação em cadeia por fissão nuclear, resultando na liberação de uma grande quantidade de energia. As principais fontes de energia físsil são o Urânio, Plutônio e o Tório, encontrados em alguns minerais, sendo eles, também, fontes de energia não renovável (STACEY, 2010). Quanto ao termo energia renovável, refere-se à energia proveniente de recursos que são regenerativos ou, para todos os efeitos práticos que, não podem ser esgotados (SINGHANIA, 2008). Exemplos de fontes de energias renováveis são o Sol, vento, chuva, marés, calor e biomassa.

Atualmente, mais de $80 \%$ da energia que consumimos é originada de combustíveis fósseis (petróleo, carvão mineral e gás natural), como mostrado na Figura 1 (INTERNATIONAL ENERGY AGENCY, 2010). Enquanto os combustíveis fósseis são formandos pela pressão e calor subterrâneo, eles são consumidos mais rapidamente do que vêem sendo criados (DEMIRBAS, 2010). Isso pode levar a escassez dessas fontes de energia.

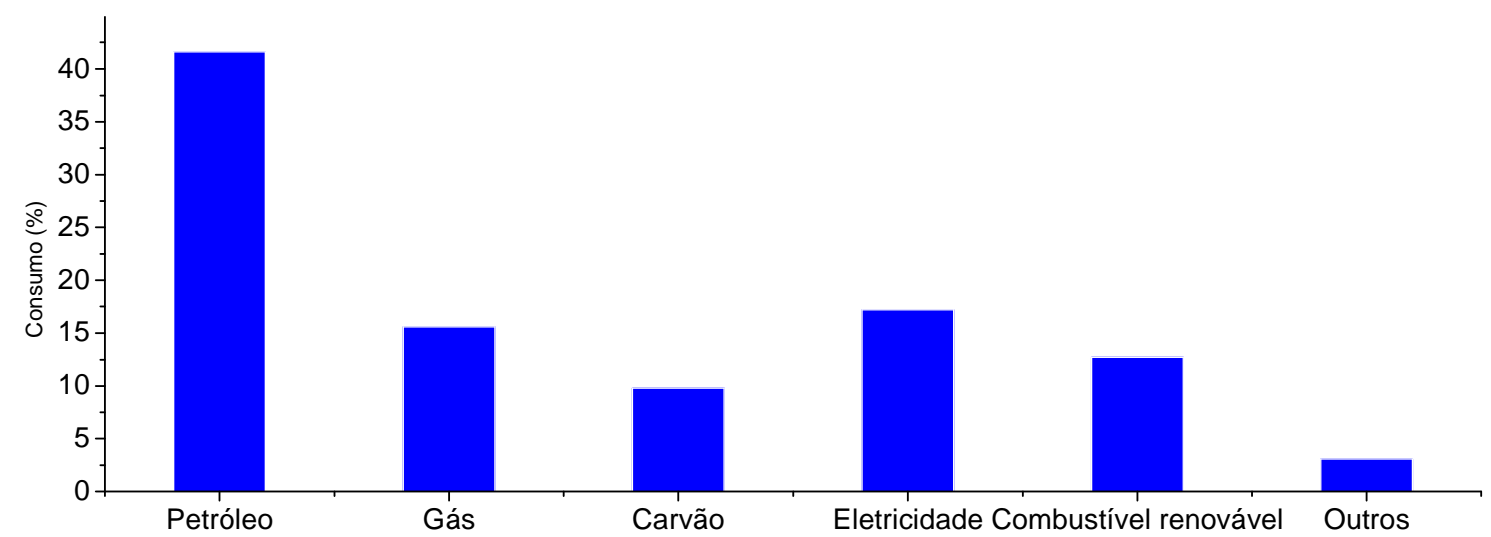

Figura 1- Consumo de energia global para o ano de 2008. Outros: inclui energia geotérmica, solar, vento, calor, etc. (INTERNATIONAL ENERGY AGENCY, 2010).

Além disso, há uma distribuição desigual de combustíveis fósseis no mundo: por exemplo, o Oriente Médio possui cerca de $63 \%$ das reservas mundiais de petróleo e é o principal fornecedor (DEMIRBAS, 2009), enquanto os Estados Unidos que consome mais de 30 bilhões de barris de petróleo por dia possui apenas cerca de $2 \%$ das reservas mundiais. Este sistema energético é insustentável por causa de questões de equidade, bem como as preocupações ambientais, econômicas e geopolíticas que têm grandes implicações no futuro. 
Curiosamente, os recursos de fontes renováveis são mais bem distribuídos do que os recursos fósseis e nucleares (GUPTA; DEMIRBAS, 2010). Além disso, o fluxo de energia proveniente de fontes renováveis é três vezes maior do que o atual uso de energia global (GUPTA; DEMIRBAS, 2010). Sendo assim, fontes de energia renováveis e sustentáveis, como os bicombustíveis, poderão desempenhar um papel importante na oferta mundial de energia.

Os bicombustíveis podem ser definidos como combustíveis derivados de fontes biológicas. Entre eles, o metano produzido através da digestão anaeróbia tem sido empregado pelos seres humanos por centenas, se não milhares de anos (DRAPCHO et. al., 2008). Mais recentemente, o etanol produzido a partir de cana-de-açúcar (etanol de primeira geração), tornou-se outro bicombustível importante. Tem sido crescente o interesse mundial pela produção deste tipo de biocombustivel, em especial pelo Brasil, que desponta como o país com as tecnologias e políticas mais avançadas do mundo devido à pioneira utilização do etanol obtido a partir da cana de açúcar, desde o ano de 1927 (STOCKERT, 2008).

Além da tradição, variedades altamente selecionadas, processos industriais sofisticados, clima e disponibilidade de terras agricultáveis garantem ao Brasil uma liderança confortável na tecnologia da produção de etanol. Entretanto, para preservar a posição privilegiada do Brasil num cenário competitivo, ele preciso haver investimentos compatíveis na geração de novas tecnologias e formação de competências (BUCKERIDGE; SANTOS; SOUZA, 2010).

Atualmente, a bioconversão de biomassa lignocelulósica em açúcares fermentáveis para produção de bioetanol (de segunda geração ou etanol lignocelulósico) tem sido considerada como uma alternativa promissora para incrementar a produção de etanol necessária para atender à demanda mundial. O processo emprega matéria-prima natural encontrada não só no bagaço-da-cana, mas em quaisquer outras fontes de biomassa vegetal (madeiras, serragens, palhas, cascas, etc.) geralmente desperdiçadas ou utilizadas de maneira pouco nobre (BUCKERIDGE; SANTOS; SOUZA, 2010). O aproveitamento destes rejeitos pode elevar consideravelmente a produção de bioetanol, sem aumentar a área plantada e o comprometimento com a produção de alimentos, acrescendo e otimizando a produtividade de processos hoje disponíveis.

No processo de obtenção de etanol lignocelulósico, o objetivo é desconstruir a parede celular para usar os polissacarídeos como fonte de açúcares fermentáveis. Entretanto, a estrutura da parede celular da biomassa é bastante complexa e durante a 
desconstrução, é necessário preservar intactos os monossacarídeos que serão usados para fermentação (BUCKERIDGE; SANTOS; SOUZA, 2010). Isso torna o processo de bioconversão delicado, necessitando que o processo seja dividido em basicamente três etapas (Figura 2): (1) pré-tratamento, que irá desagrupar o complexo carboidrato-lignina e/ou romper a própria estrutura celulósica altamente ordenada; (2) hidrólise, que irá quebrar as longas cadeias das moléculas de celulose em açúcares fermentáveis por meio de enzimas ou ácidos e por último, (3) a fermentação que irá converter os açúcaras em etanol (BUCKERIDGE; SANTO; SOUZA, 2010). Embora todos esses processos sejam funcionais, ainda não são eficientes o suficiente para permitir a produção comercial de etanol.

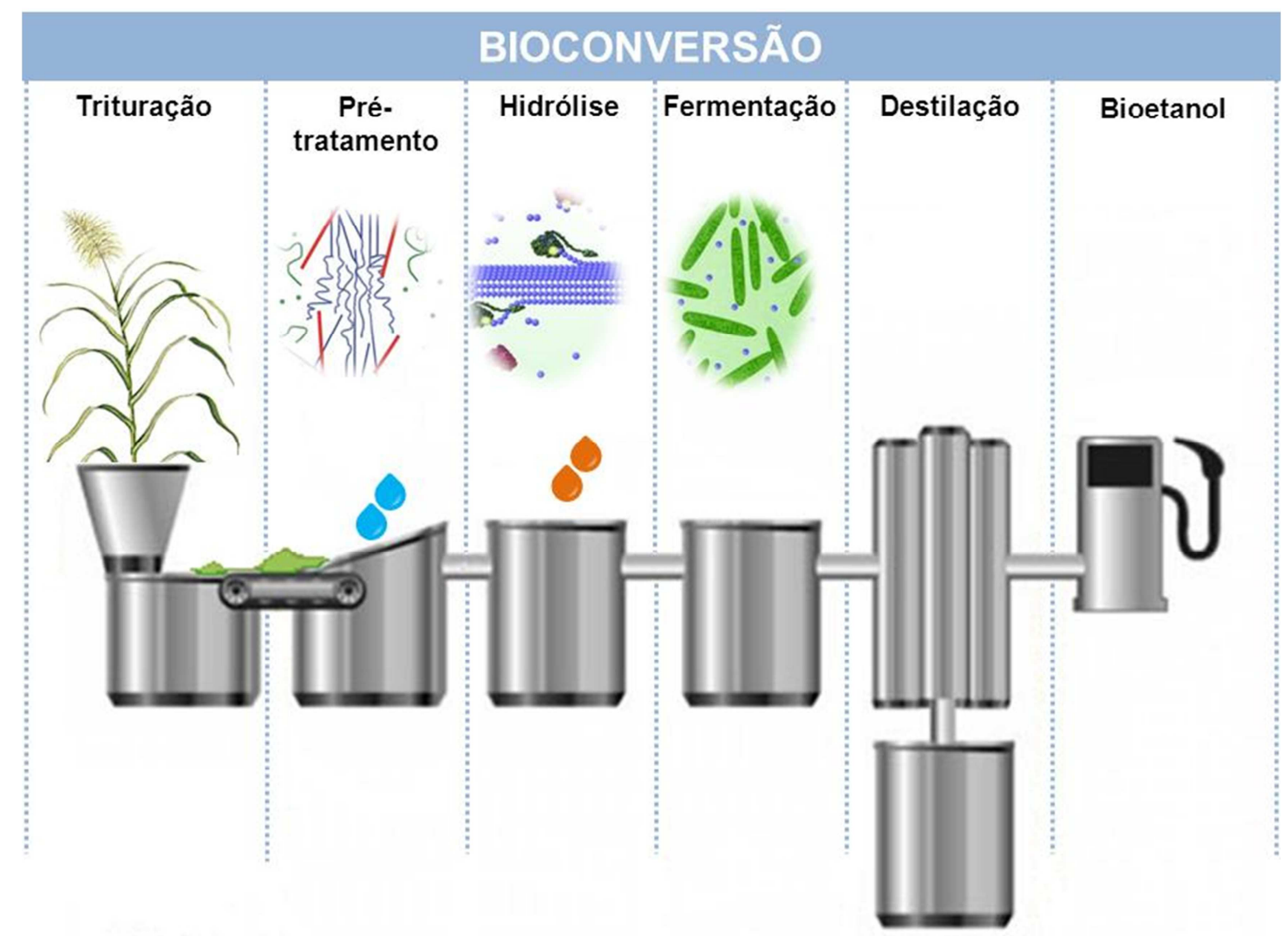

Figura 2 - Esquema mostrando as etapas do processo de bioconversão de açucares em bioetanol (ESTEVAM-ALVES; GUIMARÃES, 2009; GREENTECHMEDIA， 2010; U.S. DEPARTMENT OF ENERGY GENOMIC SCIENCE PROGRAM, 2010; HOW STUFF WORKS A DISCOVERY COMPANY: SUGARCANE, 2010).

O desenvolvimento de técnicas capazes de desconstruir a parede celular vegetal demanda o aprofundamento de conhecimentos sobre a fisiologia e estrutura da parede celular tanto da própria cana de açúcar como de outros sistemas (BUCKERIDGE; 
SANTOS; SOUZA, 2010). Além disso, investigações de processos enzimáticos de microorganismos que naturalmente já se alimentam da parede celular e, conseqüentemente, já possuem enzimas específicas para essa finalidade, podem ajudar no uso da energia disponível nos açúcares da biomassa lignocelulósica. Porém, para tal, é preciso entender o comportamento das propriedades físicas, características morfológicas e composição química e estrutural da biomassa mediante aos processos de conversão para então, se desenvolver técnicas que possam tornar a produção de etanol lignocelulósico em escala comercial. Portanto, novas metodologias de caracterização, ou mesmo, metodologias melhoradas, são necessárias. É preciso também desenvolver ou melhorar métodos de pré-tratamento eficientes e economicamente viáveis para reduzir a recalcitrância da biomassa vegetal in natura, aumentando dessa forma a eficiência da etapa de hidrólise enzimática.

Nesse sentido, o presente trabalho está inserido no âmbito do aproveitamento de resíduos lignocelulósicos da agroindústria sucroalcooleira, como é o caso do bagaço de cana-de-açúcar, para a obtenção de bioetanol (etanol lignocelulósico) por meio da sacarificação de sua fração celulósica. Além de avaliar o efeito dos pré-tratamentos químico, biológico e a combinação dos dois, ou seja, bioquímico, em fibras lignocelulósicas de eucalipto, este trabalho teve também como objetivo propor uma nova metodologia de caracterização que pode ser aplicada à cadeia produtiva de bioetanol, visando melhorias na eficiência econômica do processo de conversão da biomassa em bioetanol.

As fibras de eucalipto foram empregadas, neste trabalho, porque apresentaram qualidades estruturais superiores às fibras de bagaço de cana-de-açúcar in natura, disponível no momento. Sendo as fibras de bagaço de cana-de-açúcar in natura empregadas visando, somente, auxiliar na caracterização composicional das fibras de eucalipto em função dos pré-tratamentos. Além disso, a metodologia empregada na caracterização das fibras de eucalipto pode ser aplicada a qualquer tipo de fibra vegetal. 


\section{Revisão bibliográfica}

\subsection{Biomassa lignocelulósica: estrutura e composição}

A biomassa das plantas é formada por células vegetais organizadas em: lamela média, parede celular e membrana plasmática (Figura 3). A lamela média envolve as células, mantendo-as ligadas as células vizinhas (AGARWAL, 2006). A parede celular são fontes abundantes de material lignocelulósico e representa a fração mais expressiva da biomassa, a maior fonte de compostos orgânicos da Terra (STICKLEN, 2008).

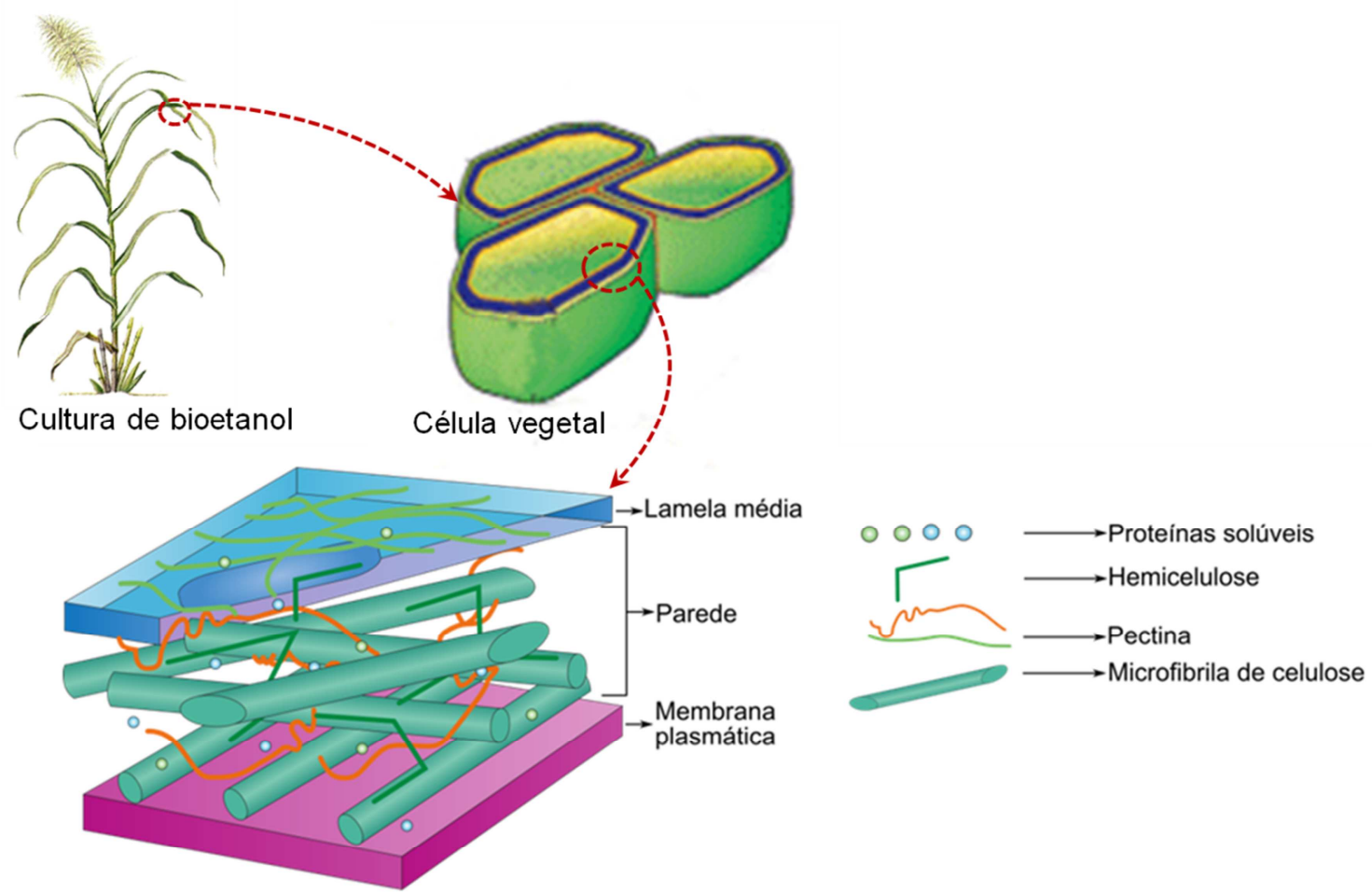

Parede da célula vegetal

Figura 3 - Representação esquemática da estrutura de células vegetais de cultura de bioetanol mostrando a membrana plasmática, lamela média, a parede celular e os principais componentes da parede celular (lignina, hemicelulose, celulose, pectina e proteínas) (HOW STUFF WORKS A DISCOVERY COMPANY: SUGARCANE, 2010; HUMAN GENOME PROJECT, 2010; SELEGHIM JR; POLIKARPOV, 2009; STICKLEN, 2008). 
A parede celular é tipicamente formada por uma rede de microfibrilas de celulose entrelaçadas por fios de hemicelulose e pectina. Os espaços vazios entre a membrana plasmática e lamela média são preenchidos por lignina, que funciona como elemento ligante dos componentes da parede celular (STICKLEN, 2008; SELEGHIM JR; POLIKARPOV, 2009).

A biomassa lignocelulósica é constituída por três frações principais que juntas, perfazem mais de $90 \%$ do total de massa lignocelulósica seca (AGARWAL, 2006). São elas: $40 \%$ celulose, $30 \%$ hemicelulose e $20 \%$ lignina (ARANTES, 2009). O percentual restante $(10 \%)$ é constituído por pectina, proteína, extrativos (materiais não-estruturais solúveis, tais como açúcares não-estruturados, material nitrogenado, clorofila e graxa) e cinzas.

O percentual composicional dos constituintes da biomassa lignocelulósica (Tabela 1) pode variar conforme a espécie vegetal, idade, fase de crescimento entre outras condições. Por exemplo, enquanto as paredes celulares de gramíneas apresentam poucos teores de lignina, aquelas de madeiras de coníferas (softwoods) são as mais abundantes neste componente.

Tabela 1 - Conteúdo de celulose, hemicelulose e lignina em resíduos agrícolas (SUN; CHENG, 2002).

\begin{tabular}{lccc}
\hline Material Lignocelulósico & Celulose $(\boldsymbol{\%})$ & $\begin{array}{c}\text { Hemicelulose } \\
(\boldsymbol{\%})\end{array}$ & Lignina $(\%)$ \\
\hline Caules folhosos & $40-55$ & $24-40$ & $18-25$ \\
Casca de nozes & $25-30$ & $25-30$ & $30-40$ \\
Espiga de milho & 45 & 35 & 15 \\
Gramíneas & $25-40$ & $35-50$ & $10-30$ \\
Papel & $85-99$ & 0 & $0-15$ \\
Palha de trigo & 30 & 50 & 15 \\
Lixo sortido & 60 & 20 & 20 \\
Sementes de algodão & $15-20$ & $80-85$ & 0 \\
Jornal & $80-95$ & $5-20$ & 0 \\
Capim Bermuda & 25 & 35.7 & 6.4 \\
Muda de grama & 45 & 31.4 & 12.0 \\
\hline
\end{tabular}




\subsubsection{Celulose}

A celulose constitui cerca de $15-30 \%$ da massa seca da parede celular primária e até $40 \%$ massa seca da parede celular secundária, onde é encontrada na forma de microfibrilas que apresentam regiões cristalinas intercaladas por regiões amorfa (Figura 4a) (STICKLEN, 2008). Cada microfibrila é formada por diversas unidas de glicose (monômero) e celobiose (dímero de glicose), unidas umas às outras ao longo de seu comprimento, por ligações de hidrogênio (Figura 4b) (GUTMAIS, 2008).

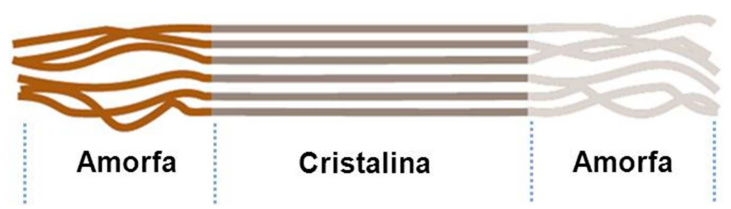

(a)

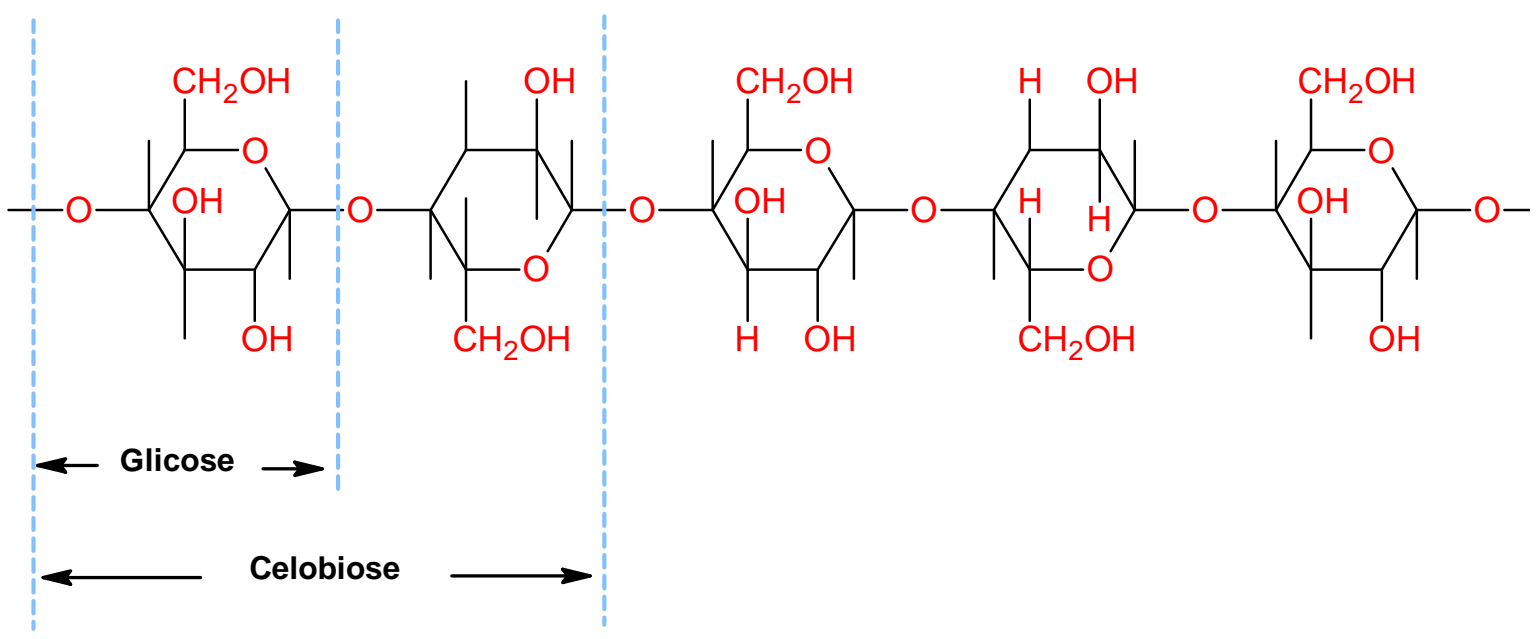

(b)

Figura 4 - (a) Rede de microfibrilas de celulose contendo regiões cristalinas intercaladas por regiões amorfas e (b) estrutura molecular parcial da hemicelulose tendo como unidades repetitivas o monômero de glicose e o dímero de glicose que é a unidadade de celobiose (COTTON INCORPORATED, 2011).

As ligações de hidrogênio inter e intramolecular são responsáveis pela manutenção das redes cristalinas e torna a celulose altamente resistente a tratamentos químicos e biológicos (GAMBARATO, 2010). 


\subsubsection{Hemicelulose}

As hemiceluloses ou polioses são polissacarídeos de cadeia linear e ramificada. Elas são amorfas e possuem peso molecular relativamente baixo, junto com a celulose, lignina, pectina e proteínas formam a parede celular das plantas (MARTINS, 2005). As hemiceluloses são depositadas de maneira intercalada nas microfibrilas de celulose, em um estágio anterior a lignificação, conferindo elasticidade e flexibilidade ao agregado de microfibrila e impossibilitando que as mesmas se toquem (AGUIAR, 2010).

A cadeia principal de uma hemicelulose (Figura 5) pode-se consistir de uma só unidade (homopolímero), como a xilana, ou de duas ou mais unidades (heteropolímero), como a glucomanana unidas entre si por ligações de hidrogênio (MARTINS, 2005; PASTORE,

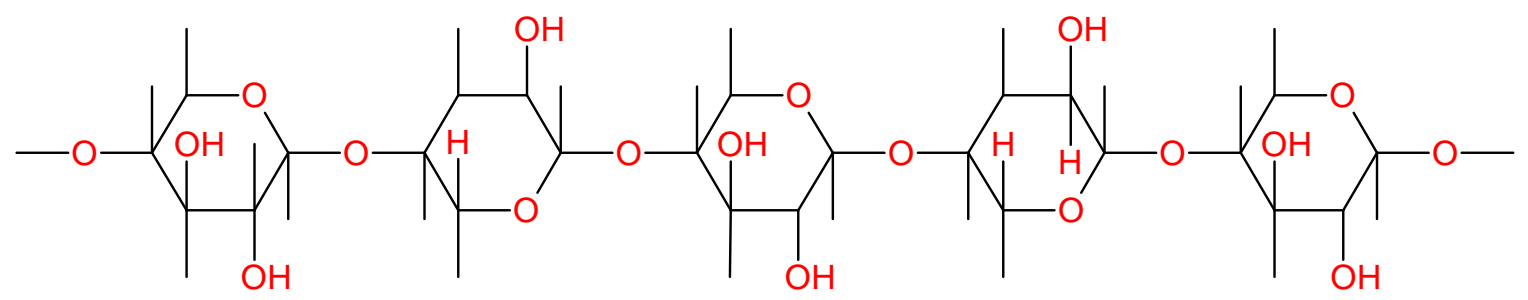

Figura 5 - Estrutura molecular parcial da hemicelulose.

2004). Os açúcares que formam as estruturas das hemiceluloses incluem pentoses, hexoses, ácidos hexurônicos e desoxiexoses. Alguns desses açucares são mostrados na Figura 6. 
Pentoses

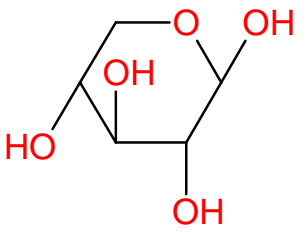

(1)<smiles>OCC1OC(O)C(O)C2OC1C2O</smiles>

(4)

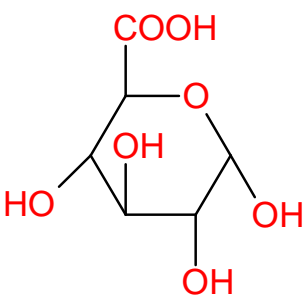

(7)

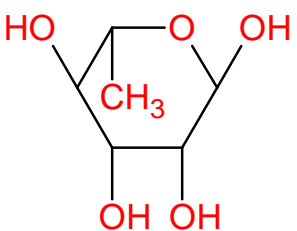

(10)

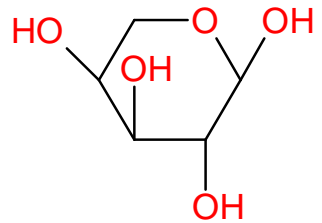

(2)

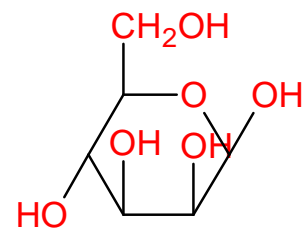

(5)

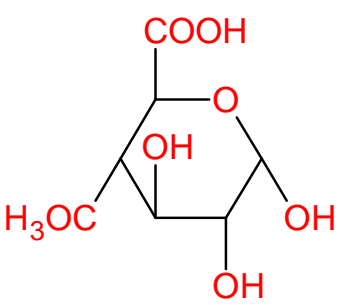

(8)

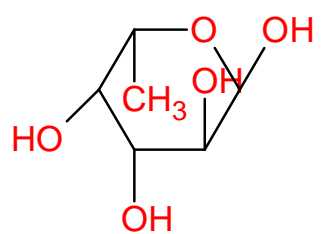

(11)

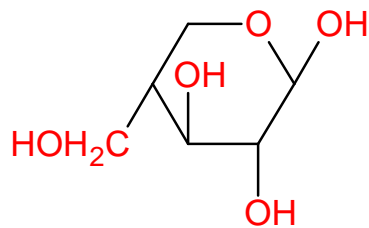

(3)

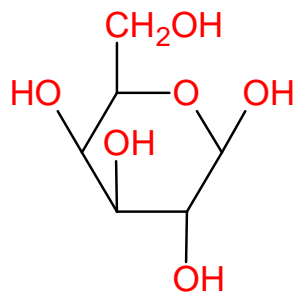

(6)

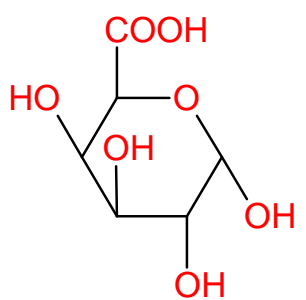

(9)

Deoxi-hexoses

Figura 6 - Representações de unidades de polissacarídeos presentes na hemicelulose: (1) $\beta$-D-Xylose, (2) $\alpha$-L-Arabinopyranose, (3) $\alpha$-L-Arabinoforanose, (4) $\beta$-D-Gluocose, (5) $\beta$-D-Manose, (6) $\alpha$-D-Galactose, (7) $\beta$-D-Ácido Glucuronico, (8), $\alpha$-D-4-0-Ácido methylglucuronic (9) $\alpha$ D-Ácido galactose, (10) $\alpha$-L-Ramnose e (11) $\alpha$-L-Fucose (FENGEL; LIN, 1984; MAREBEZI, 2009; NASCIMENTO; SILVA, 2002; PASTORE, 2004).

\subsubsection{Lignina}

A lignina é uma macromolécula tridimensional, amorfa e altamente ramificada, que pode ser encontrada abundantemente na lamela média assim como na parede 
secundária das células das plantas, porém em menor concentração (FASANELLA, 2008). A lignina apresenta em sua estrutura inúneros grupos aromáticos e alifáticos, com diversos anéis fenilpropânicos substituídos ligados por meio de diferentes tipos de ligações, como do tipo éter (hidroxilas primárias e secundárias, carbonilas, carboxilas, ésteres e ligações etilênicas) ou carbono-carbono (ARANTES, 2009; RAMIRES, 2010).

Acredita-se que a lignina seja formada a partir de condensação oxidativa de três monômeros (precursores primários): fenil-propano (álcool p-cumarílico, álcool coniferílico e álcool sinapílico) (BALOGH, 1989). A representação molecular para cada um desses monômeros é mostrada na Figura 7.<smiles>O=CC=Cc1ccc(O)cc1</smiles>

(a)<smiles>O=CC=Cc1ccc(O)c(C(=O)OCc2ccccc2)c1</smiles>

(b)<smiles>COc1cc(C#CC=O)cc(OC)c1O</smiles>

(c)

Figura 7 - Precusores primários da lignina: a) álcool trans-p-cumarílico; b) álcool trans-coniferílico e c) álcool trans-sinapílico (BALOGH, 1989).

Na madeira de eucalipto, a lignina é geralmente formada pelas unidades siringila e guaiacila (lignina $\mathrm{S}-\mathrm{G}$ ); em coníferas, é formada por unidades guaiacila e $p$-hidroxifenila (lignina G-H) (BARBOSA, 2008). Em gramíneas, como a cana-de-açúcar, a formação da lignina envolve a polimerização dos três tipos de unidades monoméricas (lignina H-G-S) (RIO et al., 2005). Na Figura 8 são mostradas essas unidades da lignina.<smiles>Cc1ccc(O)cc1</smiles>

(a)<smiles>COc1cc(C)ccc1O</smiles>

(b)<smiles>COc1cc(C)cc(OC)c1O</smiles>

(c)

Figura 8 - Principais unidades aromáticas presente na molécula de lignina: (a) $p$-hidroxifenila; (b)

Guaiacila; (c) Siringila (SANTOS, 2001). 
A estrutura química hipotética da lignina é apresentada na Figura 9.

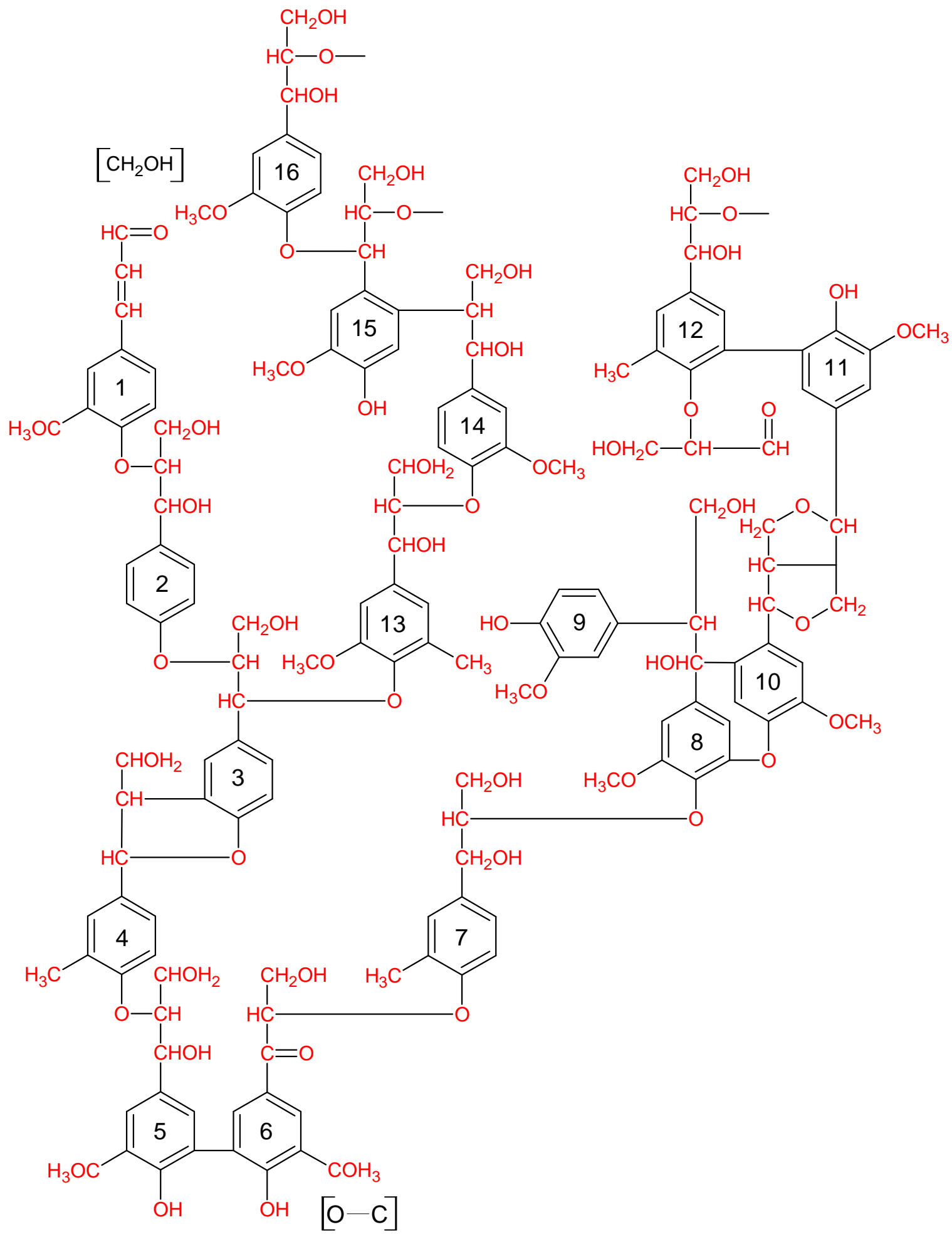

Figura 9 - Estrutura parcial hipotética de lignina (FENGEL; WEGENER, 1984). 
Durante o desenvolvimento da célula, a lignina é incorporada como o último componente na parede, envolvendo as microfibrilas celulósicas e assim fortalecendo e enrijecendo a parede celular, conferindo às plantas uma resistência mecânica (MARABEZI, 2009). Além disso, a lignina possui um importante papel no transporte de água e nutrientes das plantas e protege os tecidos vegetais da degradação química e/ ou biológica (CANILHA et al., 2010).

A lignina possui uma série de possíveis sítios reativos que estão presentes tanto na cadeia lateral das unidades fenilpropânicas, quanto nos próprios anéis aromáticos (Figura 10). Estes sítios podem sofrer uma série de diferentes reações dependendo das condições experimentais nos processos de extração de lignina (deslignificação) (BOTARO, 1996).

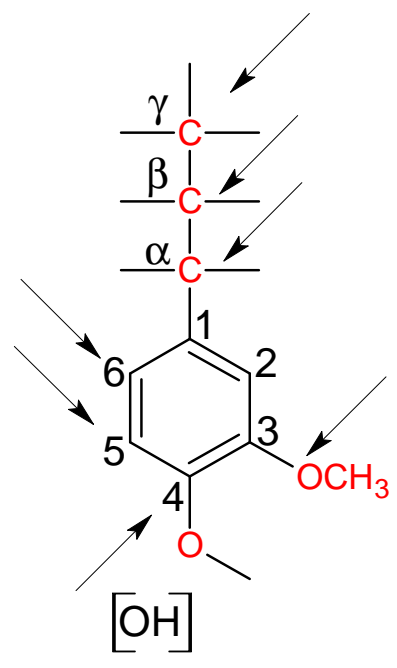

Figura 10 - Possíveis sítios reativos das unidades da lignina (BOTARO, 1996).

\subsubsection{Pré-tratamentos}

A bioconversão da biomassa lignocelulósica em etanol envolve basicamente dois processos: hidrólise da celulose para redução dos açúcares fermentáveis e a fermentação dos açúcares em etanol. A hidrolise é, geralmente, catalisada por enzimas celulases e a fermentação, por fungos ou bactérias (MOSIER et al., 2005).

Para que a hidrólise enzimática da celulose seja eficiente, é necessário que as enzimas consigam chegar até a celulose. No entanto, a parede celular vegetal é impermeável a grandes moléculas, incluindo proteínas, como as celulases. Para romper 
esta barreira, é necessário desconstruir a parede celular da planta por métodos de prétratamentos (CANILHA et al., 2010). O objetivo do pré-tratamento é alterar a estrutura de biomassa celulósica e consequentemente, tornar a celulose mais acessível para as enzimas que convertem os polímeros de carboidratos em açúcares fermentáveis como representado na Figura 11 (MOSIER et al., 2005). Além disso, o pré-tratamento visa remover a lignina e hemicelulose, reduzindo a cristalinidade da celulose e aumentando a porosidade e a área superficial do material (CANILHA et al., 2010; MOSIER et al., 2005).

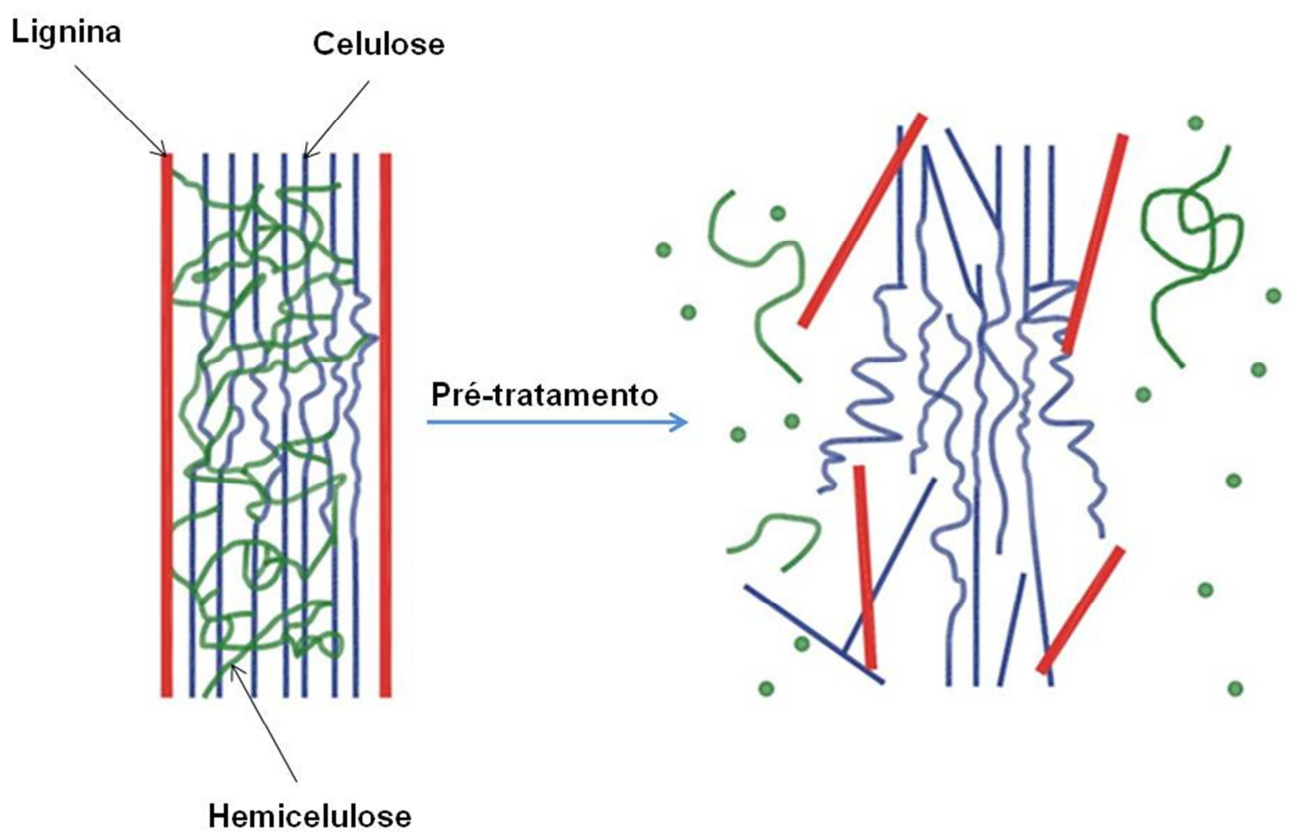

Figura 11 - Esquema das transformações que sofre a biomassa lignocelulósica durante o pré-tratamento (ESTEVAM-ALVES; GUIMARÃES, 2009; MOSIER et al., 2005).

Na bioconversão de celulose em bioetanol, um pré-tratamento é considerado bom se a acessibilidade ao ataque biológico, isto é, das enzimas, é maximizada e a formação dos co-produtos inibidores é minimizada. Existem vários tipos de pré-tratamentos que podem ser usados para aumentar a suscetibilidade da associação celulose-hemiceluloselignina e assim, melhorar a hidrólise enzimática. Estes pré-tratamentos podem ser processos físicos, biológicos e químicos, os quais, cada um possui diversos processos. Um resumo dos principais processos é apresentado na Tabela 2. 
Tabela 2 - Resumo de vários processos de pré-tratamento de biomassa lignocelulósica (ALVIRA et al , 2010).

\begin{tabular}{|c|c|c|}
\hline Pré-tratamento & Vantagens & Limitações \\
\hline Mecânico & $\begin{array}{l}\text { Reduz a cristalinidade da } \\
\text { celulose }\end{array}$ & $\begin{array}{l}\text { Consumo de energia } \\
\text { geralmente maior do que a } \\
\text { energia da biomassa inerente }\end{array}$ \\
\hline $\begin{array}{l}\text { Explosão por } \\
\text { vapor }\end{array}$ & $\begin{array}{l}\text { Degrada hemicelulose e } \\
\text { lignina; custo-benefício }\end{array}$ & $\begin{array}{l}\text { Destruição de uma parte da } \\
\text { fração xilana; ruptura } \\
\text { incompleta da matriz lignina- } \\
\text { carboidratos; geração de } \\
\text { compostos inibitórios para } \\
\text { microrganismos }\end{array}$ \\
\hline AFEX & $\begin{array}{l}\text { Aumenta a área superficial } \\
\text { acessível; remove lignina e } \\
\text { hemicelulose; não produz } \\
\text { compostos inibitórios }\end{array}$ & $\begin{array}{l}\text { não é eficiente para a biomassa } \\
\text { com alto teor de lignina }\end{array}$ \\
\hline $\begin{array}{l}\text { Explosão por } \\
\mathrm{CO}_{2}\end{array}$ & $\begin{array}{l}\text { Aumenta a área superficial } \\
\text { acessível; custo-benefício; não } \\
\text { causa formação de compostos } \\
\text { inibitórios }\end{array}$ & $\begin{array}{l}\text { Não modifica a lignina e a } \\
\text { hemicelulose }\end{array}$ \\
\hline Ozonólise & $\begin{array}{l}\text { Reduz o teor de lignina; não } \\
\text { produz resíduos tóxicos }\end{array}$ & $\begin{array}{l}\text { Necessidade de grande } \\
\text { quantidade de ozônio; custo } \\
\text { alto }\end{array}$ \\
\hline Hidrólise ácida & $\begin{array}{l}\text { Hidrolisa hemicelulose em } \\
\text { açúcares xilose e outros; altera } \\
\text { a estrutura de lignina }\end{array}$ & $\begin{array}{l}\text { Alto custo; corrosão de } \\
\text { equipamentos; formação de } \\
\text { substâncias tóxicas }\end{array}$ \\
\hline Hidrólise alcalina & $\begin{array}{l}\text { Remove lignina e } \\
\text { hemicelulose; aumenta a área } \\
\text { superficial acessível }\end{array}$ & $\begin{array}{l}\text { Exige longos tempos de } \\
\text { permanência; formação de sais } \\
\text { irrecuperável e incorporação em } \\
\text { biomassa }\end{array}$ \\
\hline Organosolv & $\begin{array}{l}\text { Hidroliza lignina e } \\
\text { hemicelulose }\end{array}$ & $\begin{array}{l}\text { Solventes precisam ser } \\
\text { drenados no reator, evaporado, } \\
\text { condensado e reciclado; alto } \\
\text { custo }\end{array}$ \\
\hline Pirólise & $\begin{array}{l}\text { Produz produtos de gás e } \\
\text { líquido }\end{array}$ & $\begin{array}{l}\text { Alta temperatura; produção de } \\
\text { cinzas }\end{array}$ \\
\hline $\begin{array}{l}\text { Campo elétrico } \\
\text { pulsado }\end{array}$ & $\begin{array}{l}\text { Condições ambientais; rompe } \\
\text { as células vegetais; } \\
\text { equipamento simples }\end{array}$ & $\begin{array}{l}\text { Processo necessita de mais } \\
\text { pesquisas }\end{array}$ \\
\hline Biológico & $\begin{array}{l}\text { Degrada a lignina e } \\
\text { hemiceluloses; requer baixas } \\
\text { energias }\end{array}$ & $\begin{array}{l}\text { Taxa de hidrólise é muito } \\
\text { baixa }\end{array}$ \\
\hline
\end{tabular}




\subsubsection{Pré-tratamento Físico}

O pré-tratamento físico consiste em fragmentar a biomassa lignocelulósica pela combinação de pulverização, trituração e moagem. Os processos mecânicos, como a moagem, reduzem o tamanho e a cristalinidade da fibra celulósica e, causam a quebra de ligações de longas cadeias moleculares. O tamanho da fibra celulósica é geralmente 10-30 mm após a pulverização e 0.2-2 mm depois de triturado ou moído (KUMAR, 2009).

\subsubsection{Pré-tratamento químico}

Esse pré-tratamento utiliza ácidos e bases para remover lignina e hemicelulose da biomassa, deixando a celulose mais acessível para a etapa de sacarificação enzimática. Para o processo ácido, o pré-tratamento pode ser a partir de ácidos diluídos ou concentrados. No caso de uso de ácidos diluídos, há dois tipos de processo: a alta temperatura (temperaturas maiores que $160{ }^{\circ} \mathrm{C}$ ) e a baixa temperatura (temperaturas menores que $160{ }^{\circ} \mathrm{C}$ ) (SUNG; SHENG, 2002). A presença de prótons no meio ácido causa a formação de íons carbônio intermediário de diferentes tipos com alta afinidade para qualquer agente nucleofílico (BOTARO, 1996). A protonação de hidroxilas ou grupos éter no átomo carbono benzílico $(\alpha-\mathrm{C})$ gera sistemas carbônio-oxiônio (Figura 12). Estes sistemas são envolvidos nas reações de fragmentação ou condensação de lignina, dependendo do tipo de nucleófilico ativo (BOTARO, 1996).<smiles>C=C=CC(C)c1ccc(OC)c(OC)c1</smiles>

Figura 12 - Conversão de grupos $\alpha$-éter para íons carbônio e oxônio, respectivamente (BOTARO, 1996). 
Reações típicas de lignina envolvendo ácido sulfúrico podem ser visualizadas na Figura 13.

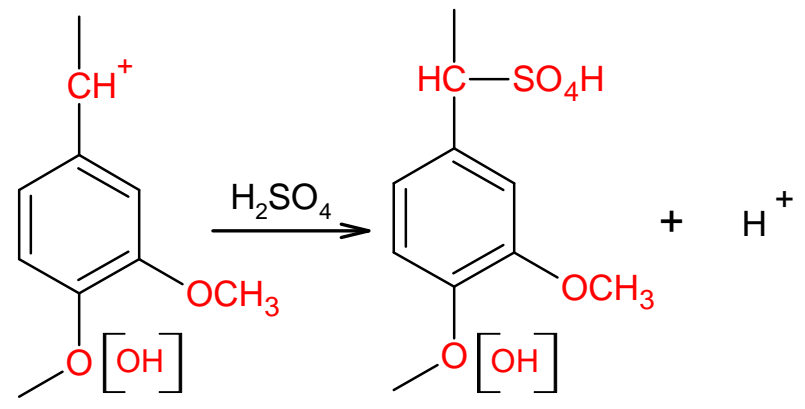

Figura 13 - Reações de unidades de lignina em ácido sulfúrico (MARABEZI, 2009).

O pré-tratamento de biomassa vegetal em recentes estudos (SILVA, 2009) possibilitou a obtenção de rendimento de $57 \%$ quando realizou um pré-tratamento de palha de cana-de-açúcar com ácido diluído a $120^{\circ} \mathrm{C}$ por 10 minutos.

\subsubsection{Pré-tratamento biológico}

Durante o processo, estes micro-organismos secretam enzimas extracelulares como a xilanase (endo-1,4- $\beta$-xilanase), que auxilia na degradação de hemicelulose, liberando lignina (OGEDA; PETRI, 2010; MENEZES; SILVA; DURRANT, 2009). O pré-tratamento de biomassa lignocelulósica com fungos pode reduzir a energia de refinação e consumo de produtos químicos nos processos polpação ou melhorar as propriedades da polpa, e ainda, reduzir o impacto ambiental negativo de processos de polpação. No entanto, o método de pré-tratamento envolvendo fungos apresenta algumas desvantagens, tais como, crescimento de fungos lento (cerca de 2-4 semanas) e perda de rendimento devido à degradação de polissacarídeos, juntamente com a degradação da lignina durante tratamento (ZHAO et al., 2002). Para superar esses problemas, uma das alternativas é o uso de enzimas isoladas no processo de polpação. Durante processos de polpação, as enzimas, como, por exemplo, as xilanases usadas neste trabalho, removem a xilana (polissacarídeos formados por unidades de D-xilose ligadas por pontes glicosídicas $\beta-1 \rightarrow 4$ na cadeia principal das hemiceluloses) depositada em fibras lignocelulósicas e 
rompem o complexo lignina-carboidrato (GOLDMAN, 2009). Em geral, as principais condições operacionais que comprometem os resultados finais no processo de prétratamento enzimático são a dosagem de enzima, temperatura, tempo de pré-tratamento, pH e métodos de lavagem de biomassa tratada, sendo aconselhável lavar a biomassa prétratada com enzimas após a aplicação do pré-tratamento (ZHAO et al., 2002).

O pré-tratamento biologico apresenta a vantagem de poder trabalhar com baixas temperaturas e em condições brandas, leva apenas algumas horas e, pode substituir ácidos em processos de pré-tratamentos, que é muito drástico e resulta em um resíduo difícil de tratar depois. Entretanto, apesar dessas vantagens, o pré-tratamento biológico é pouco usual devido o seu alto custo, recebendo mais atenção o pré-tratamento químico que é mais eficiente que os pré-tratamentos físicos.

No presente trabalho, fibras de eucalipto pré-tratadas por processo químico, biológico e a combinação dos dois, chamado aqui de bioquímico, como também, fibras de bagaço de cana-de-açúcar in natura, foram alvo de investigação. O objetivo principal foi à verificação de mudanças morfológicas e estruturais das fibras de eucalipto em função dos pré-tratamentos por meio de técnicas espectroscópicas e microscópicas de alta resolução. Vale salientar que, as fibras de bagaço de cana-de-açúcar foram usadas, somente, para auxiliar na caracterização composicional das fibras de eucalipto em função dos prétratamentos. 


\section{Materiais e Métodos}

\subsection{Materiais}

\subsubsection{Fibras lignocelulósicas}

Neste trabalho foram utilizadas fibras lignocelulósicas provenientes de eucalipto (Figura 14a) e de bagaço de cana-de-açúcar (BCA) (Figura 14b).

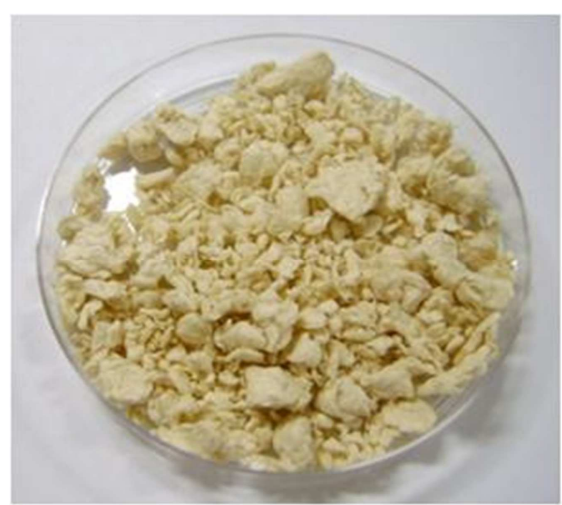

(a)

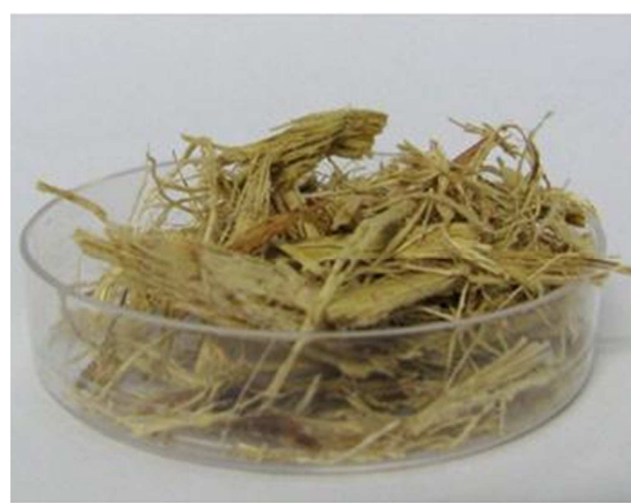

(b)

Figura 14 - Amostras de fibras lignocelulósicas empregadas neste trabalho: (a) oriundas de eucalipto; (b) oriundas de bagaço de cana-de-açúcar in natura (BCA) (na forma bruta, ou seja, sem qualquer pré-tratamento).

As fibras de eucalipto foram fornecidas pela empresa pela empresa Aracruz Celulose. Elas foram recebidas na forma de polpa branqueada, que inicialmente sofreram pré-tratamentos diversificados para a retirada de lignina e hemicelulose nos laboratórios da empresa. Nos pré-tratamentos foi utilizado inicialmente uma solução $\mathrm{NaOH}$ e, em seguida, uma solução de ácido e/ou enzima xilanase (pré-tratamento químico, biológico e bioquímico). Na Figura 15 é mostrada a representação esquemática da seqüência dos prétratamentos aplicados às fibras de eucalipto. 


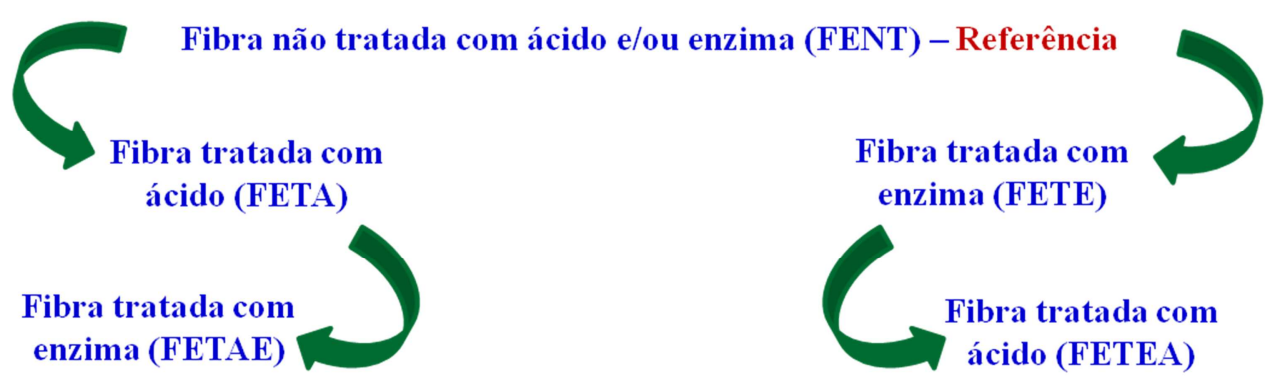

Figura 15- Representação esquemática da sequência dos pré-tratamentos aplicados às fibras lignocelulósicas de eucalipto pela empresa Aracruz Celulose, tomando como padrão de referência neste trabalho a amostra de fibra não tratada com ácido e/ou xilanase.

Devido aos pré-tratamentos, as fibras de eucalipto apresentaram qualidades estruturais superiores as apresentadas pelas fibras de bagaço de cana-de-açúcar in natura, disponível no momento - motivo pelo qual as fibras de eucalipto foram utilizadas neste trabalho como fibra lignocelulósica padrão. Além disso, a metodologia que foi utilizada neste trabalho, para a caracterização das fibras de eucalipto, pode também ser aplicada para a caracterização de qualquer tipo de fibras lignocelulósicas.

As fibras de bagaço de cana-de-açúcar (Figura 14b) foram fornecidas pelo Laboratório de Cristalografia do Instituto de Física de São Carlos, da Universidade de São Paulo. Elas foram recebidas na forma in natura, ou seja, na forma bruta sem qualquer prétratamento. Elas foram utilizadas neste trabalho para auxiliar na caracterização composicional das fibras de eucalipto em função dos pré-tratamentos.

\subsubsection{Massa de fibras lignocelulósicas de eucalipto}

Para caracterização das fibras de eucalipto via espectroscopia de fluorescência foi necessária à produção de uma massa seca. A massa foi preparada a partir de uma solução de fibras de eucalipto a $0,06 \mathrm{mg} \cdot \mathrm{mL}^{-1}$, a temperatura ambiente. Essa solução permaneceu por cerca de 20 minutos sob agitação em um banho de ultrasom para a dispersão das fibras. Em seguida, após as fibras decantarem, com o auxilio de uma micropipeta, cuidadosamente foi retirado todo excesso de água e a massa de fibra precipitada foi espalhada de forma uniforme em uma placa de Petri. A placa de Petri contendo a massa de fibra foi isolada a baixa pressão em um dessecador por cerca 16 dias para realização do processo de secagem (tempo em que visivelmente verificou-se que na superfície interior 
da tapa da placa de Petri não havia qualquer vestígio de umidade). A massa de fibra seca foi cortada na forma de um retângulo e colado em uma porta-amostra devidamente adaptado ao espectrofluorímetro. As medidas dos espectros foram feitas posicionando a amostra a um ângulo de $45^{\circ}$ em relação ao feixe de radiação incidente. Os espectros de emissão foram excitados no comprimento de onda de $370 \mathrm{~nm}$ e os de excitação detectados no comprimento de onda de máxima emissão em $455 \mathrm{~nm}$.

\subsubsection{Filmes de fibras lignocelulósicas de eucalipto}

A caracterização das fibras lignocelulósicas via microscopia exigiu a produção de filmes tendo como substratos, lâminas de vidro BK7 e lamínulas fabricadas em vidro óptico. Para a retirada de possíveis óxidos, gordura e graxa da superfície, esses substratos foram lavados com detergente e enxaguados em água ultrapura (MilliQ), em seguida, foram imersos em uma solução de ácido sulfúrico e peróxido de hidrogênio por cerca de 20 minutos. Posteriormente, as lâminas de BK7 e as lamínulas foram lavadas em água ultrapura (MilliQ) e hidrofilizadas com uma solução de água ultrapura, peróxido de hidrogênio e hidróxido de amônia por cerca de 20 minutos. Após a hidrofilização, os substratos foram lavados novamente com água ultrapura (MilliQ) e secados em jato de $\mathrm{N}_{2}$. Os filmes foram produzidos a partir de uma solução de fibras de eucalipto a 0,4 mg.mL ${ }^{-1}$, a temperatura ambiente. Como as fibras se apresentavam bastante agregadas umas as outras, foi necessário agitar as soluções em um banho de ultrassom, marca Thornton, a temperatura ambiente por 20 minutos. Em seguida, as soluções foram entornadas em béqueres contendo lâminas de vidro BK7 ou lamínulas. Após cerca de 5 minutos, com o auxilio de uma micropipeta, foi retirada toda a solução de cada béquer, deixando permanecer sob os substratos apenas uma fina camada de fibra lignocelulósica. Por fim, visando processo de secagem, os filmes foram isolados por cerca de $12 \mathrm{~h}$ a baixa pressão em um dessecador (tempo em que visivelmente verificou-se que os filmes de fibras apresentavam secos). 


\subsubsection{Lignina}

Com o intuito de avaliar o comportamento da fluorescência da lignina em função do pH e elucidar a caracterização das fibras de eucalipto em função dos tratamentos (via espectroscopia de fluorescência) foi empregado também a lignina originada de eucalipto (Figura 16a). Ela foi fornecida na forma de pó pelo Grupo de Materiais Macromoleculares e Fibras Lignocelulósicas do Instituto de Química de São Carlos, da Universidade de São Paulo.

A caracterização da lignina foi feita por meio de técnicas de espectroscopia de absorção UV-VIS e de fluorescência. Para estas etapas, preparamos uma solução de lignina a $0,05 \mathrm{mg} \cdot \mathrm{mL}^{-1} \mathrm{pH} 9$ (Figura 16b). Como essa solução de lignina era muito concentrada, foi preparada, a partir desta primeira solução de lignina, uma segunda solução (Figura 16c), esta última a 0,002 mg. $\mathrm{mL}^{-1} \mathrm{pH} 9$. Variou-se o pH de 9 a 3 usando alíquotas de uma solução $\mathrm{HCl}$ a $0,1 \mathrm{~mol} \cdot \mathrm{L}^{-1}$.

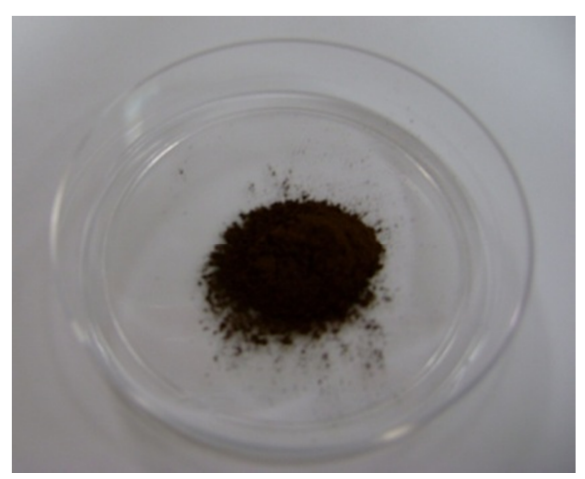

(a)

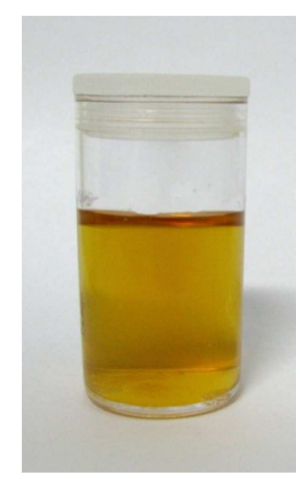

(b)

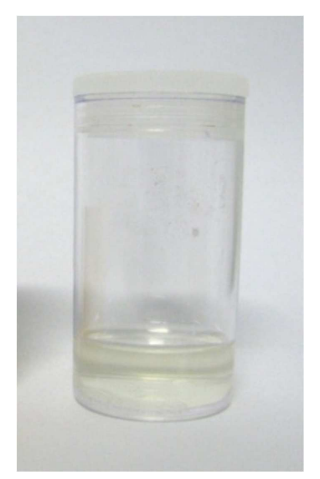

(c)

Figura 16 - (a) Amostra de lignina de eucalipto na forma de pó; (b) solução de lignina a 0,05 mg.mL ${ }^{-1}$ pH 9 e (c) solução, esta última a 0,002 mg.mL ${ }^{-1}$ pH 9.

\subsubsection{Copolímero PTHT-PPV}

Neste trabalho foi importante caracterizar a estrutura lignocelulósica em uma ampla faixa de etapas de tratamentos. Para isso, procurou-se manter a qualidade e a resolução das imagens ópticas por fluorescência com outro material, pois a lignina é modificada 
durante os processos e perdia-se, em parte, as suas propriedades de emissão. Sendo assim, foi feita a incorporação de um polieletrólito solúvel em água, o poli(cloreto de tetraidrotiofeno de xililideno), PTHT (Figura 17b). O PTHT é o precursor do poli(pfenileno vinileno), PPV (Figura 17a), que é um polímero conjugado emissor de luz. A conversão do PTHT em PPV é obtida através de tratamento térmico e irradiação luminosa. Logo, como a solução de PTHT utilizada neste trabalho apresentava parcialmente convertida, em PPV, achou-se apropriado chamar esta solução de PTHTPPV. Uma ilustração da estrutura química do PTHT-PPV é mostrada na Figura 17.

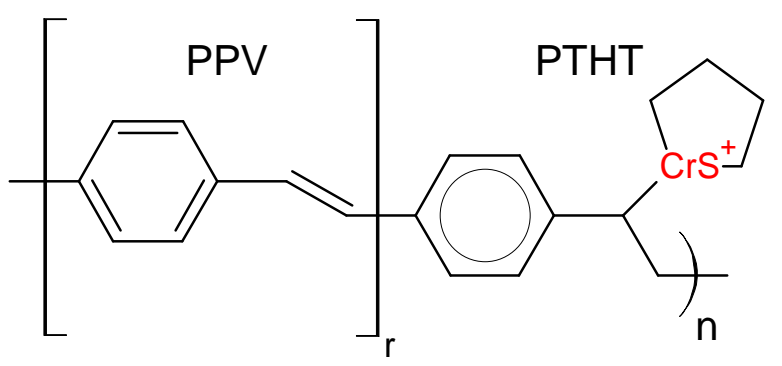

(a)

(b)

Figura 17 - Representação da estrutura química do polímero PTHT-PPV: a) Unidade repetitiva do PPV; b) Unidade repetitiva do PTHT (MAIA, 2006).

\subsection{Métodos}

\subsubsection{Espectroscopia de Absorção molecular no ultravioleta/visível (UV-Vis)}

A espectroscopia de absorção molecular baseia-se na absorção de energia por uma molécula nas regiões do ultravioleta (UV) e do visível (Vis) do espectro eletromagnético. A absorção da molécula é dependente de sua estrutura eletrônica, podendo causar alterações na energia eletrônica da mesma e resultar na excitação de um elétron presente em um orbital no estado fundamental para um orbital excitado de maior energia (COSTA et al., 2003).

Através da técnica de espectroscopia de absorção é possível quantificar a intensidade de luz absorvida por um material assim como medir a posição das bandas de 
absorção em um determinado intervalo de comprimentos de onda. A intensidade de absorção é chamada de absorbância e depende da probabilidade de interação entre a radiação incidente e as moléculas, como também da diferença entre o estado fundamental e o estado excitado.

A quantidade de luz que a amostra irá absorver é descrita pela Lei de LambertBeer que é a relação entre a intensidade da luz incidida na solução $\left(\mathrm{I}_{0}\right)$ e a intensidade da luz saindo da solução (I), ou seja,

$$
\mathrm{I}=\mathrm{I}_{0} e^{\varepsilon l c}
$$

onde $\varepsilon$ é absortividade molecular ou coeficiente de extinção, $l$ o comprimento da cubeta através da qual a luz passa e $c$, a concentração da amostra. Uma ilustração de um diagrama referente à absorção luminosa segundo a lei de Lambert-Beer é ilustrado na Figura 18.

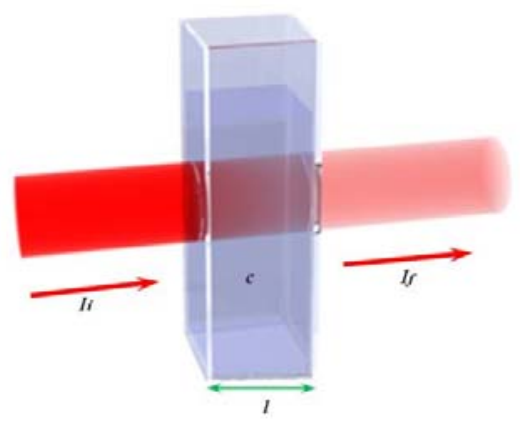

Figura 18 - Diagrama referente à absorção luminosa segundo a lei de Lambert-Beer (INSTITUTE OF PHYSICAL CHEMISTRY, 2009).

A absorbância se relaciona com a transmitância $T=\frac{\mathrm{I}}{\mathrm{I}_{0}}=\varepsilon l c$ de um material através da equação:

$$
\mathrm{A}=-\ln (T)
$$

Portanto,

$$
A=-\ln \left(\frac{\mathrm{I}}{\mathrm{I}_{0}}\right)=\varepsilon l c
$$


As transições eletrônicas observadas em moléculas são caracterizadas por orbitais do estado fundamental e do estado excitado. Logo, torna-se relevante conhecer suas características.

Os orbitais moleculares geralmente encontrados no estado fundamental (ligantes HOMO) de moléculas orgânicas são os seguintes:

Orbitais $\sigma$ - formados por ligações simples. A densidade eletrônica assume simetria cilíndrica em torno da ligação química.

Orbitais $\pi$ - se encontram envolvidos em ligações múltiplas. Os elétrons estão delocalizados e interagem com facilidade com a vizinhança.

Orbitais n - os orbitais ocupados pelos elétrons livres dos heteroátomos, como oxigênio e nitrogênio. Esse tipo de orbital não se encontra envolvido em ligações químicas e detém as características do orbital atômico.

Os orbitais (antiligantes - LUMO) importantes nos estados excitados de moléculas são:

Orbitais $\sigma^{*}$ - conhecido como sigma antiligante. Apesar de ter simetria cilíndrica, possuem um plano nodal entre os átomos.

Orbitais $\pi^{*}$ - denominado como Pi antiligante. No estado fundamental eles se apresentam delocalizados, entretanto, possuem um plano nodal ao longo do eixo da ligação.

\subsubsection{Absorção da lignina}

A lignina absorve fortemente na região UV devido à transição $\pi^{*} \leftarrow \pi$ de suas ligações duplas C-C (HALTTUNEN et al., 2001). Embora existam algumas diferenças nos espectros em UV de diferentes ligninas, um espectro em UV típico de lignina apresenta, geralmente, um máximo de absorção entre $280 \mathrm{~nm}$ e $300 \mathrm{~nm}$, devido a estruturas guaiacil e siringil e, outro máximo próximo a $230 \mathrm{~nm}$, característico de grupos fenólicos não condensados (FERNANDES, 2005; GOMES, 2009; MAEABEZI, 2009; WU; FUKAZAWA;OHTANI, 1990; HALTTUNEN et al., 2001). Um espectro na região do UV típico de lignina é mostrado na Figura 19. 


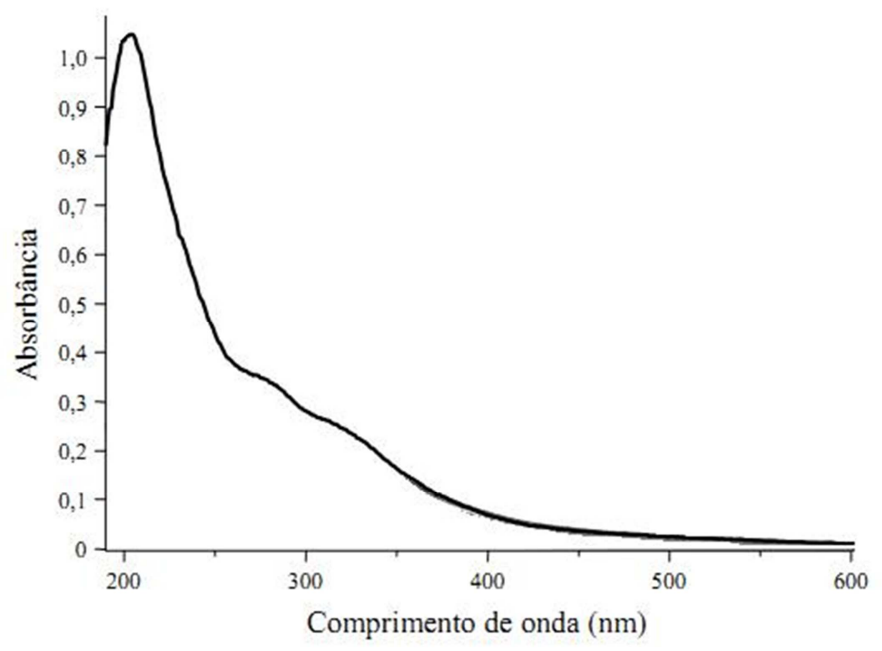

Figura 19 - Espectro de absorção na região UV da lignina de eucalipto (ALESSIO et al., 2008).

A localização e intensidade dos máximos de absorção da lignina dependem da origem, modificações química durante processos de isolamento, alterações do pH e do solvente utilizado durante as medidas (FERNANDES, 2006).

FERNANDES e colaboradores trataram lignina solúvel com ácido sulfúrico visando avaliar a influência do $\mathrm{pH}$ na precipitação da lignina (FERNANDES; MUSSATTO; ROBERTO, 2006 ). As condições de pH (variando de 12,56 (pH original) a 2,15) foram avaliadas e, para cada caso, foram analisadas a massa precipitada, bem como a coloração e a concentração de lignina solúvel. De acordo com os resultados apresentados por eles, a precipitação da lignina apenas foi significativa em valores de $\mathrm{pH}$ $<7,7$, sendo que em pH 2,15, a concentração de lignina solúvel foi reduzida de 12,44 g.L${ }^{1}$ para 2,31 g.L ${ }^{-1}$. Segundo eles, tal remoção $(81,43 \%)$ afetou fortemente a coloração da lignina, que passou de marrom escuro para amarelo claro. Além disso, eles observaram que os compostos fenólicos analisados tiveram suas concentrações reduzidas em diferentes proporções (de 74,4\% a 32,1\%), sugerindo que os compostos derivados da lignina são afetados de diferentes formas pela alteração do pH. Assim, neste trabalho foi empregado a técnica de espectroscopia UV-Vis para caracterização de mudanças na estrutura e propriedades da lignina mediante a variação do $\mathrm{pH}$.

Em um trabalho similar, mas com uma amostra diferente (TSUTAE, 2010), foi observado que em soluções ácidas há uma redução na intensidade e mudanças substanciais na forma dos espectros (para $\mathrm{pH}<5$ ). Essa mudança de intensidade em $\mathrm{pH}$ ácido pode estar associada a formação de agregados e, a mudança na forma de linha, pode 
ser devido à protonação (TSUTAE, 2010). O regime de agregação molecular favorece o espalhamento da luz e não a absorção, uma vez que o livre caminho médio do fóton aumenta e a luz, que propaga na solução, só espalha (TSUTAE, 2010). Já em soluções básicas, foi observado um aumento na intensidade dos espectros de absorção sem alterar muito suas formas - o que é devido ao fato das moléculas se encontram desagregadas, prevalecendo à forma monomérica da molécula (TSUTAE, 2010). Nesse caso, o livre caminho médio da luz é menor e passa a ser absorvida pelas moléculas (TSUTAE, 2010). Assim, neste trabalho, para caracterizar a lignina de eucalipto, baseou-se também na variação da intensidade dos máximos de absorção em função do pH, objetivando-se verifica efeitos de agregados.

\subsubsection{Absorção do PTHT-PPV}

O PTHT-PPV absorve na região do UV-Vis ( 190 a $520 \mathrm{~nm})$. Um espectro de absorbância típico do PTHT-PPV é mostrado na Figura 20.

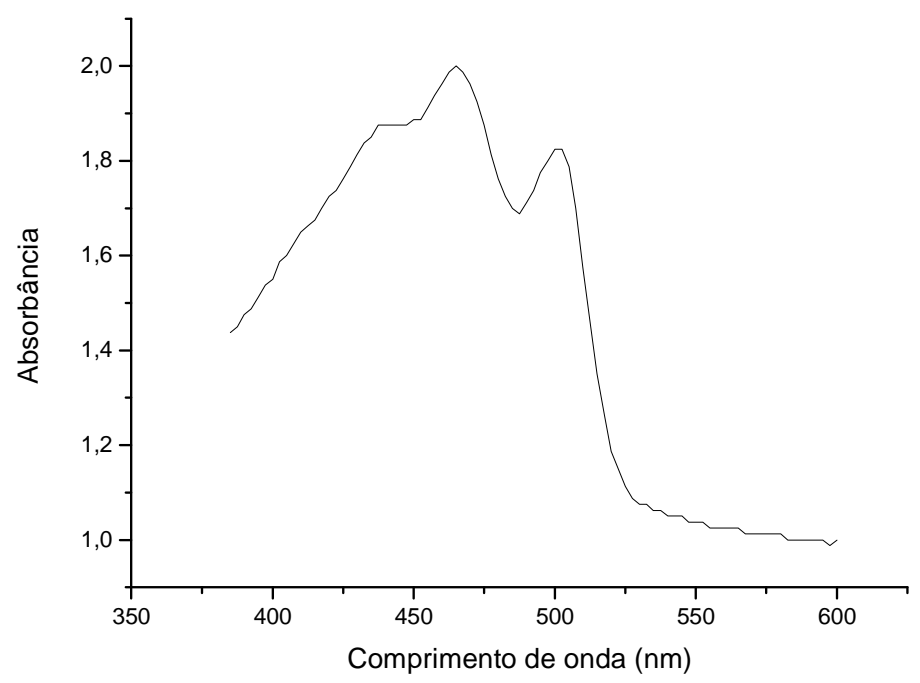

Figura 20 - Espectros de absorção na região UV do copolímero PTHT-PPV (FACETO, 2007). 
O espectro de absorbância do PTHT-PPV mostra a densidade de segmentos conjugados da rede e refere-se às transições entre os estados $\pi$ e $\pi^{*}$ (MAIA, 2006). A banda de maior intensidade da absorbância indica em que intervalo espectral a maior quantidade de segmentos absorve. Neste trabalho, utilizou-se a variação da intensidade dos máximos de absorção dessas bandas como parâmetro de referência em experimentos de adsorção entre o PTHT-PPV e as fibras de eucalipto. Isso, para verificar a afinidade entre os mesmos. A sequência do procedimento experimental utilizado pode ser mais bem compreendida no tópico 3.2.12.

No presente trabalho, tanto os espectros da solução de lignina (experimento de variação do $\mathrm{pH}$ ) quanto os de solução contendo PTHT-PPV (experimentos de adsorção) foram obtidas em um espectrômetro Hitachi U-2900 (UV-Vis) do grupo de Polímero Bernhard Gross do Instituto de Física de São Carlos - Universidade de São Paulo.

\subsubsection{Espectroscopia de fluorescência}

A espectroscopia de fluorescência se baseia no processo de perda de energia de excitação com a emissão de luz quando a molécula passa do estado excitado para o estado fundamental sem que ocorra mudança na configuração de spin eletrônico. O processo é conhecido como fluorescência. Ao contrário, o processo é chamado de fosforescência, resultando também da emissão de luz, porém, pela transição com mudança na configuração de spin (ATKINS; PAULA, 2004).

Os princípios básicos de fluorescência podem ser entendidos mais facilmente com a ajuda do diagrama Jablonski (Figura 21). O diagrama ilustra os estados eletrônicos de uma molécula fluorescente e nele pode-se observar a absorção e os vários caminhos possíveis para dissipação de excesso de energia da molécula. Na parte esquerda do diagrama são apresentados três estados singleto com spins antiparalelos: um estado singleto fundamental $\left(\mathrm{S}_{0}\right)$ e dois estados superiores singleto excitados $\left(\mathrm{S}_{1}\right.$ e $\left.\mathrm{S}_{2}\right)$. O estado de tripleto $\left(\mathrm{T}_{1}\right)$ é o com spins paralelos. 


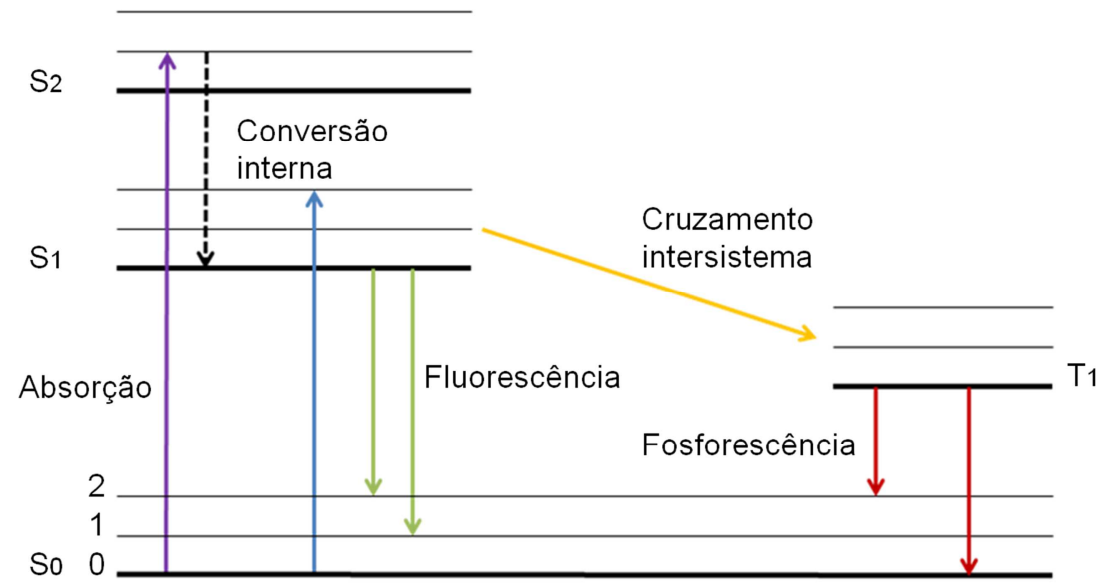

Figura 21 - Diagrama de Jabloski. Caminhos para a dissipação de energia de um estado excitado.

Quando a molécula absorve um fóton com uma determinada energia, o elétron de valência é promovido do estado fundamental para o estado excitado singleto. O processo de absorção de luz é extremamente rápido, na ordem de 1fs (SKOOG; HOLLER; CROUCH, 2009). Após a absorção de luz, a molécula termina no menor nível de vibração de $S_{1}\left(S_{1,0}\right)$ através de relaxamento vibracional e de conversão interna. O menor nível de vibração de $S_{1}$ é o ponto de partida da emissão de fluorescência $S_{0}$, decaimento não-radioativo para $\mathrm{S}_{0}$ (conversão interna) e a transição para o estado tripleto mais baixo (cruzamento intersistemas). Os tempos de vida da fluorescência são da ordem de $10^{-7}-10^{-9}$ segundos (LAKOWICZ, 2006). Nesta escala de tempo podem ocorrer diversos processos, tais como: reações de protonação, desprotonação, mudanças conformacionais de moléculas e reorientação de cromóforo. Além disso, o tempo de vida da molécula no estado excitado é dependente da competição entre emissão radiativa (fluorescência) e outros processos não radiativos de relaxação, como por exemplo, conversão interna, cruzamento intersistema e supressão de fluorescência. Estes processos correspondem aos mecanismos alternativos para as moléculas excitadas dissiparem o excesso de energia e retornarem para o estado fundamental resultando na diminuição ou supressão de fluorescência.

A espectroscopia de fluorescência tem sido utilizada como instrumento de análise em uma variedade de investigações de fibras lignocelulósicas (MACHADO, 2001; GIERER; PETTERSSON, 1977; CASTELLAN et al., 1994; RADOTIC et al., 2006, MACHADO et al,, 2001; CASTELLAN; DAVIDSON, 1994) que apresentam muitas vantagens: é barata, rápida, sensível, específica e não-destrutiva. Neste trabalho, a técnica de espectroscopia de fluorescência foi empregada para verificar mudanças estruturais das fibras de eucalipto 
em função dos pré-tratamentos, alterações estruturais da lignina em função do $\mathrm{pH}$ e a interação das fibras de eucalipto com o polímero luminescente, PTHT-PPV (experimentos de adsorção). Nas nossas medidas via espectroscopia de fluorescência, como referência, utilizamos o comprimento de onda de máxima emissão e a intensidade das bandas, para investigação das amostras (fibras, lignina e PTHT-PPV). Os espectros foram obtidos utilizando-se um espectrofluorímetro modelo Shimadzu RF-5301 PC, equipado com uma lâmpada de Xenônio (Xe) do grupo de Polímero Bernhard Gross do Instituto de Física de São Carlos - Universidade de São Paulo.

\subsubsection{Fluorescência de fibras lignocelulósicas}

Fibras lignocelulósicas, geralmente, apresentam fluorescência no intervalo de comprimento de onda 300-500 nm (CASTELLAN et al., 2007; MACHADO et al., 2001; PANDEY; UPRETI; SRINIVASAN, 1998). Acredita-se que carboidratos (celulose e hemicelulose) presentes nessas fibras pouco contribuem para a fluorescência, mas que a mesma se origina de uma série de estruturas benzênicas (cromóforos) da lignina, tais como guaiacila, estilbeno, ácido p-cumárico, ácido ferúlico, coniferil álcool, cinamil álcool, bifenil e polifenil (CASTELLAN et al., 1994). O estado S1 para benzenos simples é um estado $\pi-\pi^{*}$, onde cruzamento entre sistemas é ineficiente e a fluorescência é esperada. Para estruturas benzênicas da lignina, a única excessão a este comportamento é atribuído à estrutura fenilcoumarina, considerado fracamente fluorescente devido a um estado $n-\pi^{*}$ (HEITNER; DIMMEL; SCHMIDT, 2010). Os espectros característicos de excitação (A) e emissão (B) para a fibra de eucalipto são mostrados na Figura 22. 


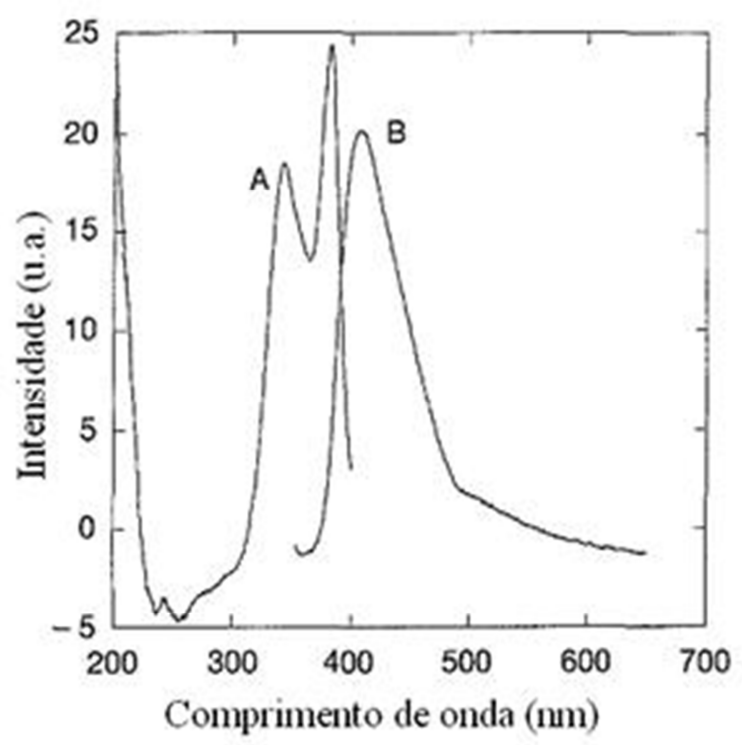

Figura 22 - Espectros de uma amostra de eucalipto: (A) excitação, com comprimento de máxima emissão em 410 nm; (B) Emissão, com comprimento excitação em 344 nm (PANDEY; UPRETI; SRINIVASAN, 1998).

A fluorescência da lignina pode ser aumentada após a remoção de grupos carbonilas que se comportam com agente supressor (HEITNER; DIMMEL; SCHMIDT, 2010;

ALBINSSON; LUNDQUIST; STOMBERG, 1999).

\subsubsection{Fluorescência do PTHT-PPV}

A origem da fluorescência do polímero PTHT-PPV (localizada aproximadamente no intervalo de comprimentos de onda 500-700 nm) está substancialmente relacionada com a natureza conjugada do PTHT-PPV. O espectro de fluorescência do PTHT-PPV bandas atribuídas às transições energéticas de segmentos de grande tamanho de conjugação, com tipicamente 3 ou 4 bandas (MARLETTA, 2001). Um exemplo de um espectro de fluorescência do PTHT-PPV pode ser visualizado na Figura 23. 


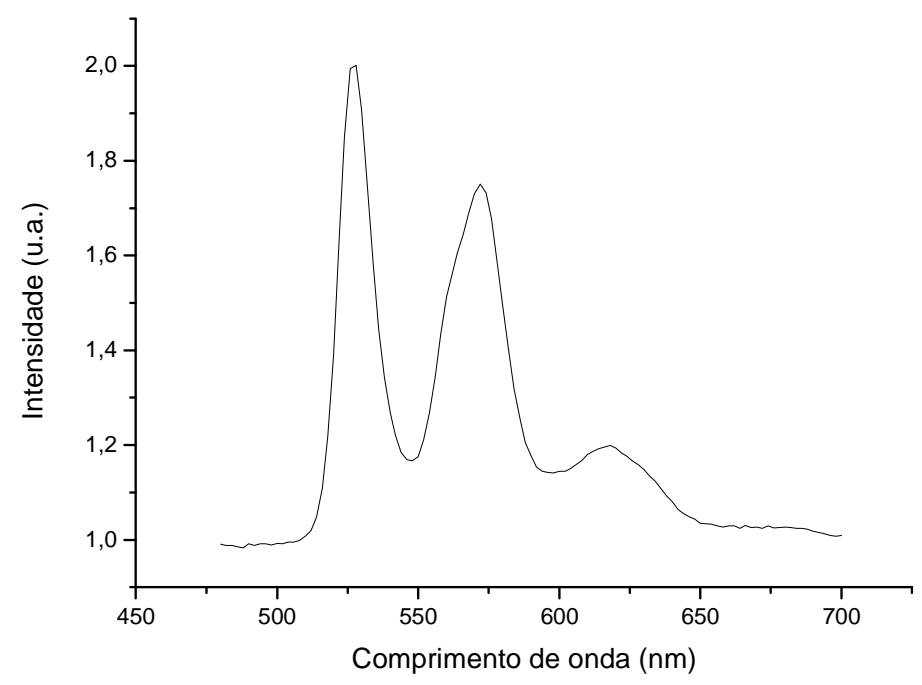

Figura 23 - Espectro de fluorescência do copolímero PTHT-PPV mostrando a três bandas de emissão (FACETO, 2007).

\subsubsection{Ressonância Magnética Nuclear}

A ressonância magnética nuclear $(\mathrm{RMN})$ é uma técnica espectroscópica utilizada para observar a reorientação do spin nuclear sob a aplicação de um campo magnético. Como uma técnica poderosa e não-destrutiva, a espectroscopia RMN vem sendo bastante empregada na caracterização de materiais lignocelulósicos (HIMMELSBACH, 2000; GILARDI; ABIS; CASS, 1995; ATALLA et al., 1980; HATFIELD et al, 1987; REDDY; GUDURI; RAJULU, 2009; RAMIRES et al., 2010). A nível molecular e atômico, ela é capaz de detectar e quantificar mudanças estruturais decorrentes a processos de deslignificação. Neste trabalho, a técnica foi empregada para caracterização das fibras de eucalipto pré-tratadas diferentemente. Além disso, a técnica RMN também foi usada para obter espectros de bagaço de cana-de-açúcar sem qualquer tratamento para facilitar a identificação das bandas nas fibras de eucalipto pré-tratadas.

As análises das fibras de eucalipto foram realizadas em um espectrômetro VARIAN UNITY INOVA (Laboratório de Ressonância Magnética Nuclear do Instituto de Física de São Carlos - Universidade de São Paulo) operando na freqüência de 100 $\mathrm{MHz}$ e $400 \mathrm{MHz}$ para ${ }^{13} \mathrm{C}$ e ${ }^{1} \mathrm{H}$, respectivamente. Uma rotação da amostra em torno do 
ângulo mágico de $5 \mathrm{kHz}$ foi usada em todos os experimentos. O esquema de excitação utilizado foi à polarização cruzada com rampa de radiofreqüência ramp-CPMAS (COOK, 2004; MAO et al.,2000), combinado com supressão de banda laterais usando a técnica Total Suppression of Spinning Sidebands (TOSS) (CP/MAS - TOSS RMN) (DIXON et al., 1982) e desacoplamento heteronuclear de ${ }^{1} \mathrm{H}$ em alta potência (BENNETT et al., 1995). Os espectros foram obtidos com tempos de contato de $1 \mathrm{~ms}$, tempo de aquisição de $15 \mathrm{~ms}$ e intervalos de remagnetização de $2 \mathrm{~s}$. Os espectros ${ }^{13} \mathrm{C} \mathrm{CP} / \mathrm{MAS}$ foram usados para se obter informações locais dos principais grupos funcionais da lignina, celulose e hemicelulose e através da variação da intensidade dos picos inferirem em mudanças estruturais nas fibras de eucalipto devido ao pré-tratamentos.

\subsubsection{Espectroscopia na região do infravermelho}

A espectroscopia na região do infravermelho (convencionalmente chamada de Fourier Transform Infrared Spectroscopy- FT-IR) fundamenta-se na absorção de radiação infravermelha por moléculas de um determinado material. Trata-se de uma ferramenta importante para a investigação de grupos funcionais, elucidação estrutural e identificação de um dado material, que pode ser orgânico ou inorgânico. Isto é possível porque os átomos que formam a molécula interagem entre si proporcionando vibrações intramoleculares, que variam de acordo com a estrutura, composição e os diferentes modos de vibração. Para varrer essa gama de frequiência, utiliza-se o infravermelho.

As moléculas podem absorver energia proveniente de radiação eletromagnética, sofrendo vários tipos de excitação (eletrônica, rotacional, mudança de spin e deformação de ligação, entre outras). Em temperaturas acima do zero absoluto, todos os átomos e moléculas estão em vibração contínua com relação uns aos outros (HSU, 1999). Quando a frequência de radiação específica é igual à frequência de vibração natural da molécula, a molécula absorve a radiação (SILVERSTEIN, 2007). O instrumento utilizado na medida mede a quantidade de radiação absorvida proveniente da diferença de intensidade entre o feixe de referência e a do feixe transmitido.

Os números de onda de absorção relativos ao modo de vibração dependem da força de ligação química entre dois átomos, e a intensidade de absorção da diferença de 
momento dipolar nesta mesma ligação. Dessa forma, certos grupos de átomos dão origem a bandas que ocorrem basicamente na mesma freqüência, independente da estrutura da molécula. É exatamente a presença destas bandas características de grupos funcionais que possibilitam através de simples análise do espectro e consulta às tabelas de correlação, caracterizar a função química a qual pertence o material. Por meio desta técnica é possível observar algumas alterações, principalmente se houver o desaparecimento ou a formação de novos grupos químicos, os quais são claramente detectados na região do infravermelho. Assim, um gráfico de intensidade de radiação versus freqüência do espectro de infravermelho permite caracterizar os grupos funcionais de um padrão ou de um material desconhecido.

A espectroscopia na região do infravermelho tem sido apresentada na literatura como uma ferramenta poderosa na análise de fibras lignocelulósicas. Essa técnica é capaz de fornecer informações valiosas que podem complementar técnicas como ${ }^{13} \mathrm{C} \mathrm{CP} / \mathrm{MAS}$ RMN, por exemplo. Neste trabalho, foi empregada a técnica de FTIR para investigação das mudanças estruturais das fibras de eucalipto em função dos pré-tratamentos. Além disso, a técnica FTIR, foi empregada também para medir bagaço de cana-de-açúcar, sem qualquer tratamento, para facilitar a identificação das bandas dos espectros das fibras de eucalipto pré-tratadas diferentemente.

As análises de FTIR das fibras de eucalipto e bagaço de cana-de-açúcar, foram realizadas na região entre 800 e $2000 \mathrm{~cm}^{-1}$ em um espectrofotômetro Smiths Illuminat IR II(FTIR microspectrometer) do Laboratório de Filmes Finos do Instituto de Física de São Carlos, da Universidade de São Paulo. O modo de medida utilizada foi a Attenuated Total Reflection (ATR). A técnica ATR permite que amostras sólidas ou líquidas sejam analisadas diretamente, sem a necessidade de preparação.

\subsubsection{Microscopia óptica campo claro}

A microscopia óptica campo claro é uma ferramenta, essencial na investigação de materiais biologicos. Nessa técnica, a luz viaja ao longo do eixo óptico, através da objetiva em direção da amostra que está sendo observada. A amostra então é vista pela luz que ela reflete. No modo fluorescência, a técnica se baseia no fenômeno que 
determinado material emite energia detectável, em luz visível, quando irradiados com a luz de um comprimento de onda específico. O material investigado por esta técnica pode ser fluorescente em sua forma natural ou tratado com produtos quimicos fluorescentes.

Neste trabalho, a microscopia óptica campo claro foi empregada para investigação de efeitos de pré-tratamentos da estrutura da fibra de eucalipto e determinar parâmetros que permitam estabelecer à dinâmica e, a eficiência dos processos envolvidos na ação enzimática ou ácida. Tais fibras foram analisadas, por um microscópio óptico campo claro, modelo Olympus BX41, equipado com dois filtros polarizadores (U-25ND25 e U25ND6), uma objetiva com aumento de 40X e uma ocular de 10X. Sendo que na aquisição de imagens de fluorescência, as fibras foram iluminadas com luz originada de uma lâmpada de mercúrio filtrada por um filtro que só deixava passar luz ultravioleta, enquanto que, as imagens no modo transmissão, foram obtidas iluminando as amostras com luz originada de uma lâmpada de halogênio.

Devido à escala de tamanho das fibras de eucalipto $(\mu \mathrm{m})$ e por ser transparentes à passagem de luz, foi utilizado o polímero PTHT-PPV, que é solúvel em água e altamente fluorescente objetivando-se, sobretudo, melhorar a visualização das fibras. A aplicação de PTHT-PPV foi realizada depositando alguns microlitros $(\mu \mathrm{L})$ sobre a superfície do filme (em uma região perto de uma das bordas do substrato), deixando-o difundir na camada de fibra. A Figura 24 mostra um dos filmes de fibras lignocelulósicas de eucalipto, destacando (linha pontilhada em vermelho) a região contendo o PTHT-PPV. A região em azul se deve a marcação de especificação da amostra no lado oposto (do substrato) do vidro.

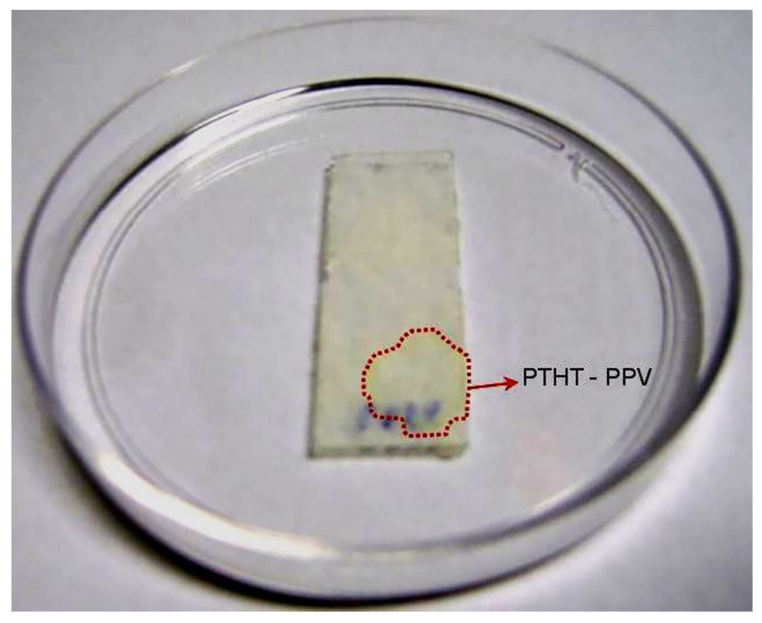

Figura 24 - Filme de fibra lignocelulósica de eucalipto tendo como substrato vidro BK7, destacando (linha pontilhada em vermelho) a região contendo o PTHT-PPV. A mancha em azul trata-se de uma marca feita no lado oposto do substrato para identificação da amostra. 


\subsubsection{Microscopia eletrônica de varredura por emissão de campo}

A microscopia eletrônica de varredura por emissão de campo (Field Emission GunScanning Electron Microscope - FEG-SEM) é uma das técnicas de caracterização mais versátil atualmente, encontrando aplicações em diversos campos do conhecimento. Nesta técnica, a interação de um fino feixe de elétrons focalizado sobre a área ou o microvolume a ser analisado gera uma série de sinais que podem ser utilizados para caracterizar propriedades da amostra como, por exemplo, a superfície topográfica.

Na produção de imagens de alta resolução, por meio de microscopia eletrônica de varredura, os sinais de maior interesse referem-se aos elétrons secundários e retroespalhados. Os elétrons são emitidos termionicamente a partir de um cátodo de tungstênio ou hexaboreto de lantânio $\left(\mathrm{LaB}_{6}\right)$ e acelerados através de um ânodo. Sendo também possível obter elétrons por efeito de emissão de campo.

A técnica FEG-SEM, tem sido relatada como uma ferramenta importante na avaliaçãodos efeitos de pré-tratamentos em materiais lignocelulósicos (LHONEUX et al., 1988). Essa ferramenta é capaz de fornecer dados necessários para o desenvolvimento de novos métodos de processamento de substratos lignocelulósicos, visando à conversão biológica subsequente.

Neste trabalho, a microscopia eletrônica de varredura por emissão de campo, foi empregada para investigação das mudanças na morfologia superficial das fibras de eucalipto em função dos pré-tratamentos, como também, para comparação com as imagens de eucalipto produzidas através de microscopia de fluorescência confocal varredura laser. $\mathrm{Na}$ produção de imagens das fibras de eucalipto, empregou-se um microscópio eletrônico de varredura por emissão de campo Zeiss modelo SUPRA-35 do Laboratório Interdisciplinar de eletroquímica e cerâmica (LIEC) da Universidade Federal de São Carlos. A tensão de aceleração (EHT) usada para analisar os filmes lignocelulósicos foi de $2.00 \mathrm{kV}$ e, distâncias de trabalho de 3 e $4 \mathrm{~mm}$. 


\subsubsection{Microscopia de confocal fluorescência varredura laser}

A microscopia confocal de fluorescência varredura laser (do inglês Laser Scanning Confocal Microscopy - LSCM) é uma ferramenta poderosa e não-destrutiva que permite a produção de imagem de materiais biológicos com alta resolução espacial. Assim, como o microscópio óptico de fluorescência (campo claro), o LSCM também utiliza a fluorescência para a obtenção das imagens. A diferença é que no confocal é possível aumentar o contraste da imagem microscópica e obter imagens de diferentes planos da mesma amostra, através de um pequeno orifício, o pinhole, que bloqueia a luz fora de foco. Um esquema do funcionamento do sistema típico é apresentado na Figura 25.

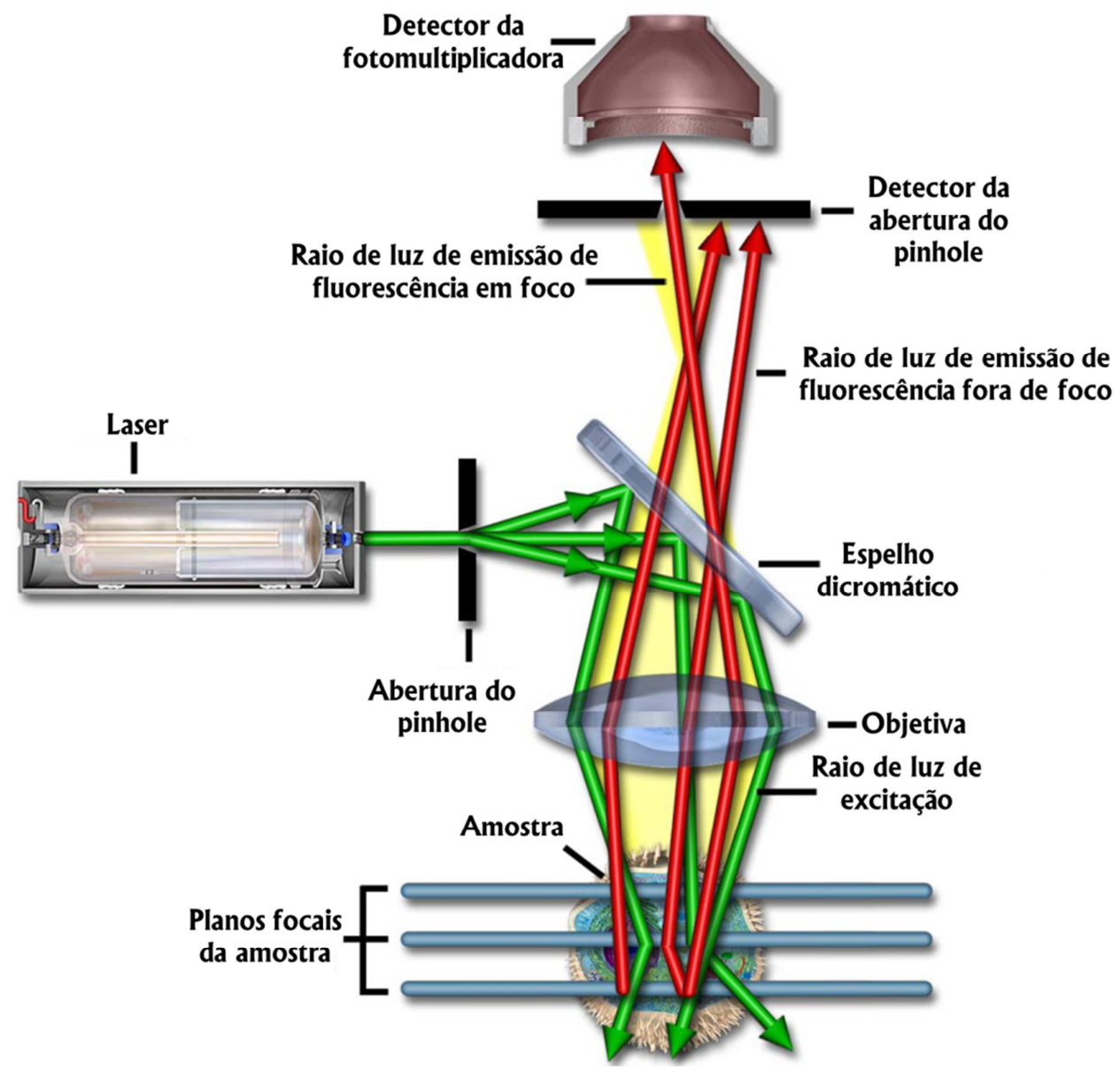

Figura 25 - Esquema do microscópio confocal de fluorescência varredura laser, mostrando como o pinhole bloqueia a luz fora de foco (CLAXTON; FELLERS; DAVIDSON, 1979). 
Neste trabalho, foi utilizado um microscópio confocal de fluorescência varredura laser, Leica modelo TCS-SP5 AOBS, para aquisição de imagens de altíssima resolução e 3D das fibras de eucalipto, objetivando-se a comparação com as imagens obtidas por microscopia eletrônica de varredura (FEG-SEM) a partir da parede externa. A técnica LSCM, também foi utilizada para a investigação da difusão do PTHT-PPV nas mesmas. Os experimentos de fluorescência e difusão foram realizados no Laboratório Multiusuário de Microscopia Confocal (LMMC), do Departamento de Biologia Celular e Molecular e Bioagentes Patogênicos, da Faculdade de Medicina de Ribeirão Preto, da Universidade de São Paulo.

O microscópio confocal de fluorescência que utilizado neste trabalho, é equipado com vários lasers: diodo- linha 405 nm, argônio - linhas 458, 476, 488, 496 e 514 nm, $\mathrm{HeNe}$ - linha 543 nm, HeNe - linha 594 nm e HeNe - linha 633 nm. No presente trabalho, foi empregada a linha $405 \mathrm{~nm}$ do laser de diodo para excitar as amostras de fibras de eucalipto. As imagens foram obtidas usando uma objetiva de 60X de imersão a óleo e, posteriormente, editadas com o auxilio do software LAS-AF (Leica Application Suite Advanced Fluorescence).

O experimento da difusão do PTHT-PPV nas fibras lignocelulósicas de eucalipto, em tempo real, foi realizado da seguinte forma: uma área selecionada da amostra foi verificada com microscópio confocal, em seguida, com auxílio de uma micropipeta, foi depositado uma gota de PTHT-PPV em uma região sobre a superfície do filme de fibras, especificamente, próximo à área selecionada, permitindo assim que o processo de difusão fosse capturado de forma contínua.

\subsubsection{Interação e adsorção entre as fibras de eucalipto e o polímero luminescente}

O processo de adsorção baseia-se na tendência de uma superfície sólida em contato com uma solução tem tendência a acumular uma camada superficial de moléculas de soluto. A solução é chamada de adsorvato e o sólido, adsorvente. Atualmente, vários estudos têm demonstrado a capacidade de fibras lignocelulósicas em se adsorverem outros materiais. Essas fibras são constituídas por macromoléculas, as quais possuem sítios ativos adsorssivos, tais como grupos carboxilas, carbonilas, aminas e hidroxilas. 
A adsorção pode ocorrer tanto por mecanismos físicos quanto por mecanismos químicos (HU, 2003). A adsorção física ocorre, quando forças intermoleculares de atração entre as moléculas do líquido e a superfície do sólido, são maiores do que as forças de atração entre as próprias moléculas do fluido. As moléculas do fluido aderem-se à superfície do sólido e, o equilíbrio é estabelecido entre o fluido adsorvido e o restante que permaneceu na fase líquida. O calor de adsorção é pequeno e da mesma ordem de grandeza dos calores de condensação. Na adsorção química, há o envolvimento de interações químicas entre o fluido adsorvido e o sólido adsorvente, devido à transferência de elétrons, equivalente à formação de ligações químicas entre o adsorvato e a superfície do sólido. Na adsorção física, são formadas camadas moleculares sobrepostas. Na adsorção química, é formada uma única camada molecular adsorvida (CAMBUIM, 2009).

A capacidade de retenção de adsorvatos por adsorventes é comumente avaliada por meio de isotermas de adsorção. A forma da isoterma é a primeira ferramenta no diagnóstico da natureza da adsorção (MORENO-CASTILLA, 2004). Uma isoterma de adsorção consiste de uma série de medidas da quantidade adsorvida em função da pressão de equilíbrio do gás em temperatura constante ou da concentração no equilíbrio, no caso da adsorção em solução (NAFFRECHOW, 2007).

Neste trabalho, a interação adsorssiva entre as fibras de eucalipto e o polímero luminescente PTHT-PPV, foi investigada por um método desenvolvido no laboratório do grupo de Polímero Bernhard Gross do Instituto de Física de São Carlos - Universidade de São Paulo. O método, conhecido como Arraste (TSUTAE, 2009), consistiu em determinar, após o processo de centrifugação, através de espectroscopia de absorção (UVVis) e fluorescência, a redução da intensidade de emissão da solução residual contendo o polímero luminescente PTHT-PPV que, não foi adsorvido nas paredes das fibras.

Nos experimentos de arraste, foi utilizado, inicialmente, uma solução contendo 10 $\mathrm{mL}$ de $\mathrm{H}_{2} \mathrm{O}$ MilliQ e uma alíquota de $50 \mu \mathrm{L}$ de PTHT-PPV, cujo espectro de fluorescência foram assumidos como padrão de referência. No caso das fibras pré-tratadas com ácido e/ou xilanase, os experimentos prosseguiram com a adição de alíquotas de 10 mg em 10 mg de fibras nessa solução. Já no caso das fibras não pré-tratada com ácido e/ou xilanase (FENT), foi necessário reduzir a quantidade de fibra. Sendo o experimento realizado com a adição de alíquotas de $2 \mathrm{mg}$ em $2 \mathrm{mg}$ de fibras na solução contendo o PTHT-PPV. 
Para cada quantidade de fibra adicionada tornou-se necessário centrifugar a solução em uma ultracentrífuga da marca EPPENDORF a 3000 rpm por 3 minutos. Após a centrifugação, uma alíquota do sobrenadante foi retirada e colocada numa cubeta de quartzo de $1 \mathrm{~cm}$ de caminho óptico. Em seguida, foram realizadas medidas de absorção óptica UV-VIS com o espectrofotômetro HITACHI U-2900 e, medidas de fluorescência com o espectrofluorímetro SHIMADZU RF-5301PC. Foram utilizados os máximos de absorção e fluorescência, de cada medida, como parâmetro de referência. Assim, caso o PTHT-PPV aderisse às fibras, a intensidade da fluorescência e absorbância deveria cair proporcionalmente ao aumento da concentração de fibras na solução. A sequência do procedimento experimental, denominado método de arraste, utilizado na investigação da dinâmica de interação entre as fibras de eucalipto e o polímero, pode ser mais bem compreendido pelo o fluxograma experimental apresentado na Figura 26.

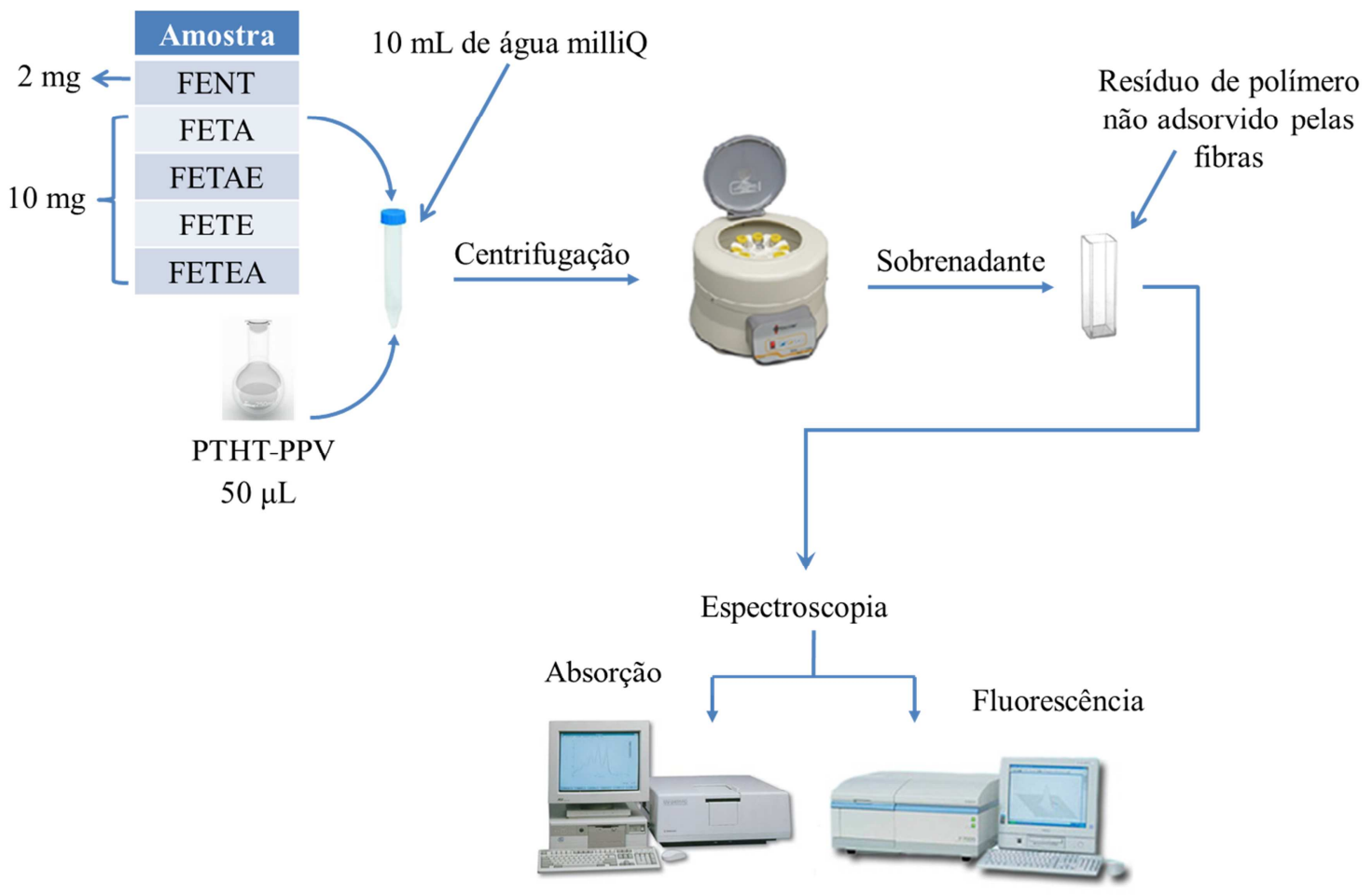

Figura 26 - Fluxograma do procedimento experimental do método de arraste aplicado na investigação da interação adsorssiva entre as fibras de eucalipto e o polímero luminescente PTHT-PPV. 


\subsubsection{Microscopia de imagem de tempos de vida de fluorescência}

A microscopia de imagem de tempos de vida de fluorescência (do inglês Fluorescence Lifetime Imaging Microscopy - FLIM) é uma técnica que permite a obtenção de imagens baseando-se na diferença das taxas de decaimento exponencial da fluorescência de uma amostra fluorescente. $O$ interesse principal dessa técnica é o tempo de vida do estado excitado das moléculas fluorescentes, em vez da quantidade de luz emitida (BODDEKE, 1996). Dessa forma, o FLIM pode funcionar como um cronômetro molecular para observar uma variedade de eventos interessantes.

As imagens obtidas por FLIM têm como base, a aplicação de múltiplas cores com marcadores fluorescentes para a observação da distribuição celular de moléculas biológicas como as proteínas, lípidios, ácidos nucleicos e iões, entre outros. Cada marcador fluorescente apresenta um tempo específico de duração para a emissão de fluorescência no seu estado excitado, sendo geralmente representado em imagens FLIM em conceitos de cores. Detectando as diferenças nesse tempo é possível distinguir cromóforos que emitem fluorescência no mesmo comprimento de onda, assim como, casos nos quais exista autofluorescência.

Estudos recentes tem demonstrado que, a técnica FLIM é uma poderosa ferramenta para estudos espacialmente resolvidos de síntese da parede celular, degradação da lignina, polpação e para a localização de marcadores fuorescentesempregados para imunomarcação de madeira ou de fibras de madeira (HAFRÉN, 2009). Neste trabalho, a técnica FLIM foi utilizada para investigar a interação do PTHT-PPV em fibras de eucalipto. Os tempos de vida da fluorescência da lignina e do PTHT-PPV foram determinados em um espectrofluorímetro SPEX Fluorolog- $\tau 2$ do Laboratório da empresa LEICA MICROSYSTEMS situado em Mannheim, Alemanha. 


\section{Resultados}

\subsection{Caracterização das fibras lignocelulósicas e lignina}

\subsubsection{Fluorescência das fibras de eucalipto}

Partes consideráveis dos trabalhos com biomassa lignocelulósica tratam a lignina como sendo a responsável pela fluorescência. Por isso, supõe-se que, com os prétratamentos, mudanças nas propriedades de fluorescência das fibras podem ocorrer após o processo de tratamento. Neste sentido, a caracterização óptica por metodologias de fluorescência, para verificar mudanças estruturais nas fibras lignocelulósicas em função dos pré-tratamentos é desejável. Neste trabalho, foi realizada essa investigação para fibras de eucalipto que sofreram diferentes tipos de pré-tratamentos.

Na Figura 27a são mostrados os espectros de emissão e excitação de fibras de eucalipto após sofrerem pré-tratamentos somente com ácido (FETA), com ácido e xilanase (FETAE), somente com xilanase (FETE) e, com xilanase e ácido (FETEA). As fibras foram depositadas por decantação sobre placa de Petri formando filmes espessos. Os espectros da fibra FENT, assumida neste trabalho como padrão de referência (que não sofreu os pré-tratamentos com ácidos ou xilanase) são mostrados para efeito de comparação. Os espectros de emissão (entre 400 e $700 \mathrm{~nm}$ ) foram excitados no comprimento de onda $370 \mathrm{~nm}$ e os de excitação (entre 300 e $400 \mathrm{~nm}$ ), foram detectados no comprimento de onda máxima emissão em torno de $455 \mathrm{~nm}$.

A Figura 27 b compara as intensidades da fluorescência que foram normalizadas no comprimento de máxima emissão, tendo como referência a emissão da FENT. Observa-se que as fibras que foram pré-tratadas com ácido e/ou xilanase, possuem intensidades de fluorescência maiores que a das FENT. 
(a)

(b)
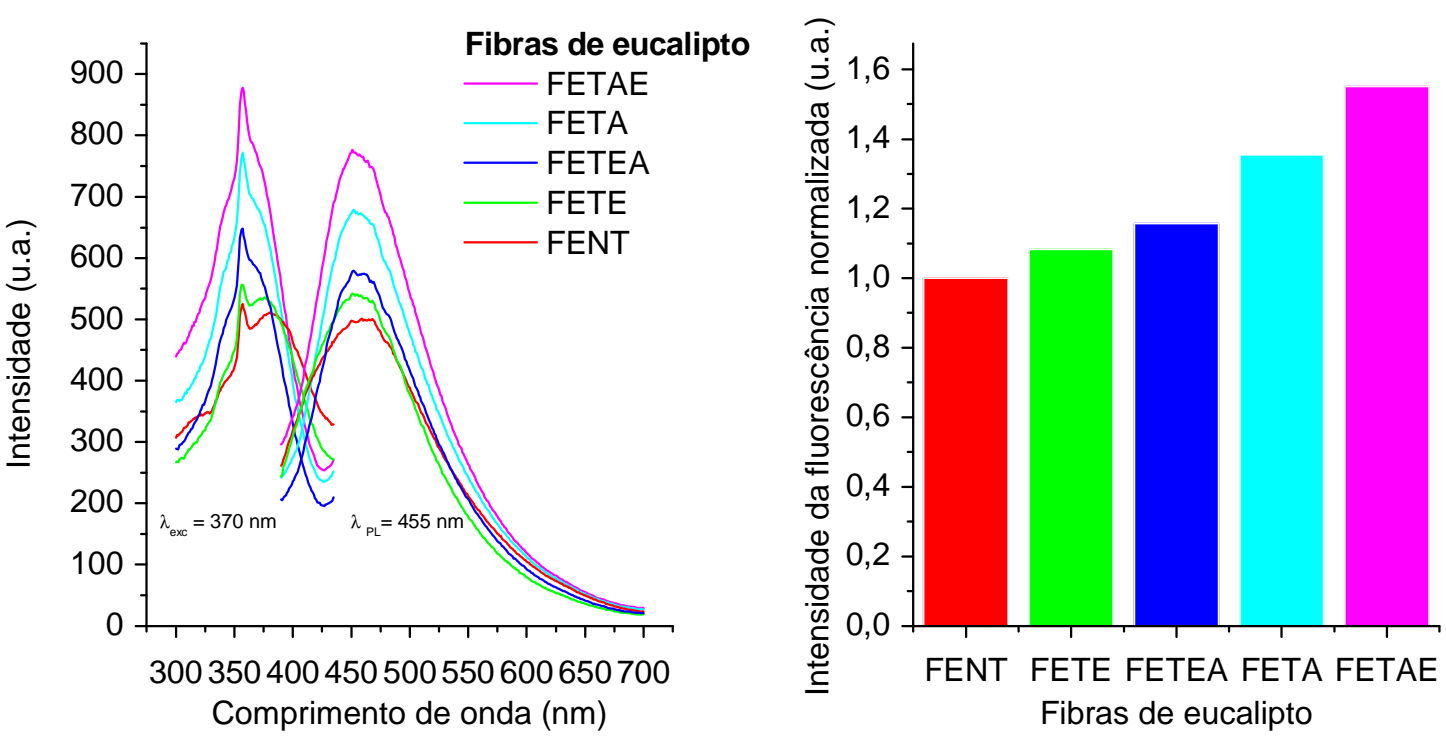

Figura 27 - (a) Espectros de excitação com intensidade máxima de emissão $\lambda_{\text {em }}$ em $455 \mathrm{~nm}$ (à esquerda) e de fluorescência (à direita) com excitação fixado em 370 nm; (b) Distribuição de intensidades de fluorescência para das fibras de eucalipto: não tratada com ácido e/ou xilanase (FENT), tratada com ácido (FETA), tratada com ácido e xilanase (FETAE), tratada com xilanase (FETE) e tratada com xilanase e ácido (FETEA).

Na Figura 27a, nota-se que as fibras de eucalipto (FENT, FETE, FETAE, FETA e FETEA) apresentaram fluorescência entre 400 e $700 \mathrm{~nm}$, concordando com as posições espectrais previamente relatadas na literatura (TYLLI; FORSSKAHL; OLKKONEN, 1992). Como será visto na seção 4.1.2, esta emissão está associada a transições ópticas originadas na lignina. Da comparação dos espectros das fibras pré-tratadas com ácido e/ou xilanase, em relação ao espectro FENT, observa-se ligeiros deslocamentos espectrais para maiores comprimentos de ondas, sendo mais evidente nos espectros cujas fibras foram pré-tratadas inicialmente com ácido, ou seja, os espectros FETA e FETAE. Observa-se ainda, um aumento na intensidade de fluorescência em toda a faixa espectral da FETAE, na região de comprimentos de ondas entre 417-700 nm da FETA, entre 417$494 \mathrm{~nm}$ da FETE e entre 428-536 nm da FETEA, ou seja, um alargamento dos espectros nessas faixas de emissões. Além disso, verifica-se um decréscimo na intensidade da fluorescência na região de comprimentos de ondas entre 390-417 nm do espectro FETA, entre 390-407 nm e 494-700 nm do espectro FETE e nas regiões entre 390-427 nm e 536$700 \mathrm{~nm}$ do espectro FETEA. Em relação à distribuição de intensidade de fluorescência apresentada na Figura 27b, observa-se, claramente, que a intensidade da fluorescência nas fibras de eucalipto aumenta consideravelmente em função dos pré-tratamentos. É evidente que as maiores intensidades de fluorescência é exibida pelas fibras pré-tratadas 
inicialmente com ácido (FETAE e FETA). Isso pode ser um indicativo que a fluorescência em fibras lignocelulósicas pode não estar relacionada somente com o teor de lignina, mas também, com a remoção de grupos moleculares pelo próprio prétratamento, que podem afetar a fluorescência do material em uma dada região espectral.

Efeitos similares foram observados por OMESTEAD e colaboradores que analisaram fibras de abeto negro (picea mariana) branqueada e não branqueada com peróxido, sendo ambas pré-tratadas com ácido (OMESTEAD et al, 1995) Eles utilizaram a fluorescência para avaliar o comportamento estrutural das fibras em função dos processos de deslignificação. A intensidade de emissão das fibras também aumentou após o pré-tratamento com ácido, mostrando, que a remoção de grupos moleculares, como grupos carbonilas, desativa o processo de transferência de energia entre diferentes elementos estruturais na lignina (ALBININSSON et al,1999).

A eficiência da fluorescência de complexos moleculares pode estar associada também à presença de agregados moleculares. Processos de migração do estado excitado podem ser responsáveis pelo decréscimo da emissão, pois aumentam a probabilidade de decaimento não radiativo, uma vez que este estado excitado pode migrar até centros supressores (MAIA, 2006; FACETO, 2007). Como os pré-tratamentos podem remover a lignina e, proporcionar uma desagregação da lignina, espera-se que a eficiência de emissão aumente após os pré-tratamentos. Na próxima seção será examinado os processos ópticos em solução aquosa de lignina para diferentes valores de $\mathrm{pH}$. Com isso, espera-se verificar efeitos de agregação e desprotonação dos radicais moleculares com a variação do $\mathrm{pH}$.

\subsubsection{Fluorescência e absorção da lignina}

Para investigar as mudanças estruturais na lignina mediante solubilização, o pH de uma solução de lignina de eucalipto a $0,002 \mathrm{mg} \cdot \mathrm{mL}^{-1}$ foi abaixado de 9 à 3 . Os espectros de absorção, excitação e fluorescência da lignina para os diferentes pH são mostrados na Figura 28. O pH da solução de lignina, foi abaixado titulando-se solução $\mathrm{HCl}$ a 0,1 mol... 
(a)

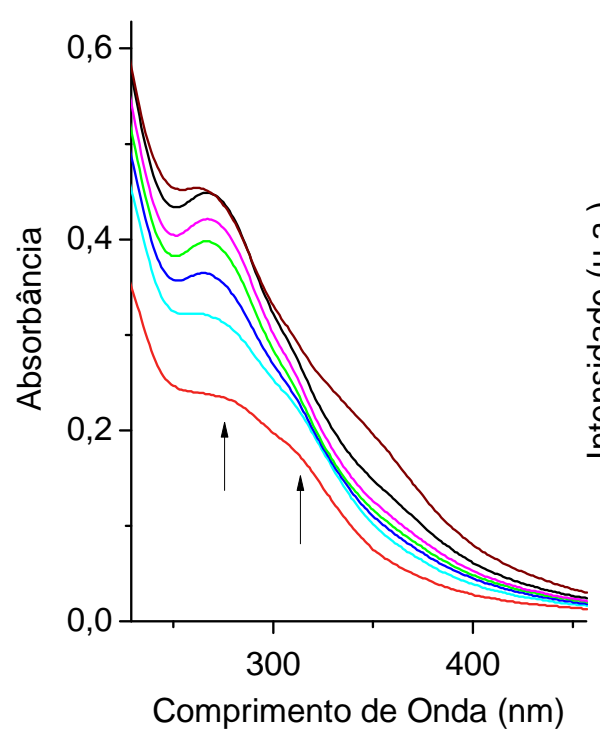

(b)

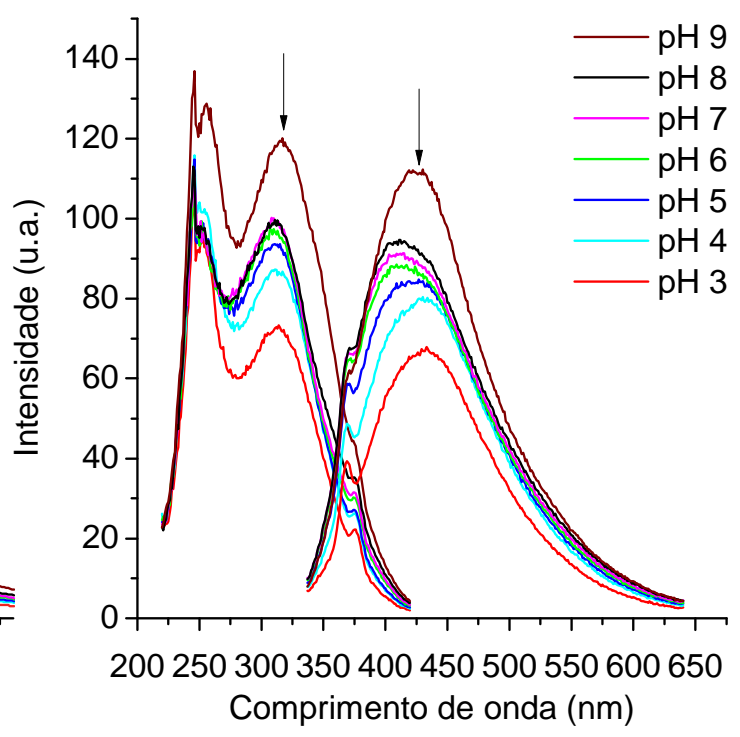

Figura 28 - Espectros de lignina mostrando em diferentes pH: (a) absorções e (b) excitação com comprimento de emissão máxima entre $410-433 \mathrm{~nm}$ (à esquerda) e fluorescência (à direita) com comprimento de excitação máxima $\left(\lambda_{\text {exc }}\right)$ em 320 nm.

Conforme visto na Figura 28a, todos os espectros de absorbância apresentaram uma banda em torno de $270 \mathrm{~nm}$ atribuída aos grupos fenólicos (XU, 2008), como os vários anéis aromáticos presentes na molécula de lignina. Observa-se um aumento na absortividade e um estreitamento desta banda com o aumento do $\mathrm{pH}$. Uma segunda banda é observada em torno de $314 \mathrm{~nm}$, devido a grupos fenólicos conjugados em ácido pcumárico e, em ácido ferúlico (CAO; TAN, 2006). Em comparação, a menor absortividade da lignina em pH menores (ácidos), pode estar associada a uma provável protonação dos radicais como hidroxilas e carboxilas, encontrados nos monômeros que formam a lignina (seção 2.1.3). A formação de agregados moleculares para valores de $\mathrm{pH}$ baixo ( $\mathrm{pH}$ ácido) não podem ser descartados nesse experimento, já que a lignina possui baixa solubilidade para valores de $\mathrm{pH}$ ácidos. Uma agregação poderia afetar os estados moleculares e, também, o livre caminho médio do fóton na solução, o que reduziria a absorbância (TSUTAE, 2010).

Quanto aos espectros de emissão e excitação apresentados na Figura 28b, observase que a lignina (em diferentes $\mathrm{pH}$ ) apresentou emissão (excitação) entre os comprimentos de onda 350-600 nm (250-400 nm), correspondendo às mesmas regiões espectrais da emissão e excitação nas fibras de eucalipto. Da comparação, verifica-se uma redução na intensidade da fluorescência que, pode ser devido à agregação dos monômeros de lignina que emitem nesta região. Visto que, a solubilidade da lignina decresce com a 
redução do pH (FERNANDES et al., 2006), o efeito contrário, é observado em pH alto, quando as estruturas moleculares se encontram mais afastadas, sendo provavelmente possível a clivagem de ligações fracas e a conseqüente remoção de estruturas que suprimem a fluorescência como, por exemplo, de grupos carbonilas. Para elucidar estes resultados, as fibras de eucalipto foram analisadas por meio da técnica de espectroscopia de ressonância magnética nuclear com polarização cruzada. Os resultados são apresentados a seguir.

\subsubsection{Ressonância Magnética Nuclear}

A espectroscopia de ressonância magnética nuclear com polarização cruzada (associada à rotação em torno do ângulo mágico e supressão de bandas laterais) (CP/MAS - TOSS RMN) é uma ferramenta extremamente poderosa para elucidação estrutural de macromoléculas como a lignina. Neste trabalho, a técnica foi empregada para investigar mudanças estruturais dos principais componentes (celulose, lignina e hemicelulose) de fibras de eucalipto com diferentes tratamentos. Para facilitar a interpretação das mudanças estruturais dessas fibras foi obtido também espectro ${ }^{13} \mathrm{C}$ CP/MAS RMN de bagaço de cana de açúcar in natura (sem qualquer tratamento).

$\mathrm{Na}$ Figura 29, são apresentados os espectros ${ }^{13} \mathrm{C}$ CP/MAS RMN das fibras de eucalipto (FENT, FETA e FETAE) e de bagaço de cana-de-açúcar in natura (BCA). As atribuições ao deslocamento químico das fibras lignocelulósicas de eucalipto e bagaço de cana-de-açúcar, foram feitas com base em resultados da literatura (GILARDIA; ABISB; CASSA, 1995; ATALLA et al, 1980; EARL; VANDERHART, 1980; HATFIED et al, 1987; REDDY; GUDURI; RAJULU,2009; RAMIRES et al, 2010) (Tabela 3). 


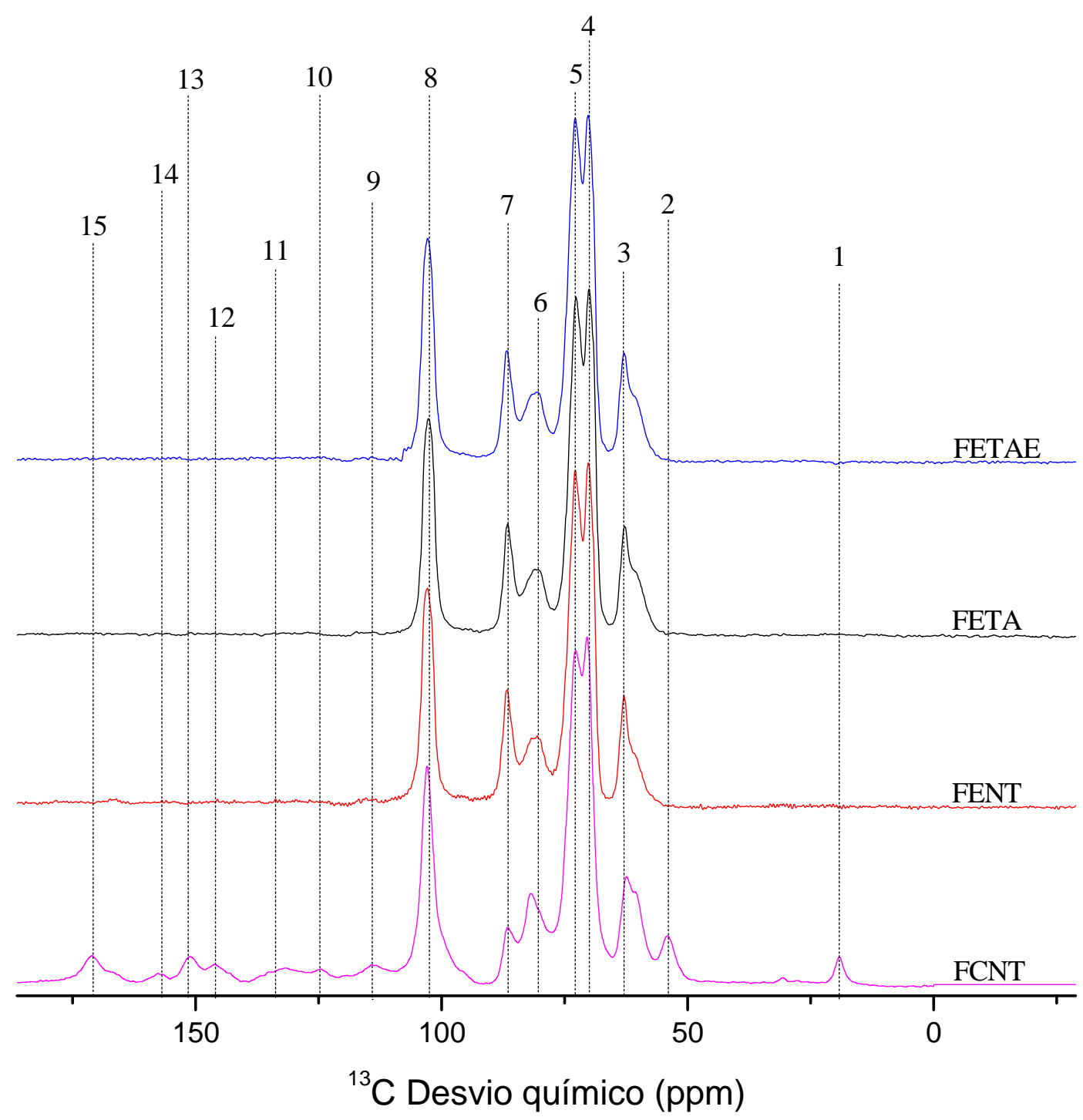

Figura 29 - Espectros ${ }^{13} \mathrm{C}$ CP/MAS RMN: bagaço de cana-de-açúcar não pré-tratada (BCA), fibra eucalipto não pré-tratada com ácido e/ou xilanase (FENT), fibra de eucalipto tratada com ácido (FETA) e fibra de eucalipto pré-tratada com ácido e xilanase (FETAE).

A análise comparativa entre os espectros obtidos por ${ }^{13} \mathrm{C} \mathrm{CP} / \mathrm{MAS}$ mostrados na Figura 29 das fibras de eucalipto pré-tratadas e bagaço de cana-de-açúcar indicam a presença de sinais relacionados à celulose, hemicelulose e lignina em todas as fibras. Dos sinais detectados no bagaço de cana-de-açúcar, somente os sinais entre a região de 102-56 ppm são visualizados nas fibras de eucalipto. Isso se deve aos pré-tratamentos sofridos pelas fibras de eucalipto, os quais podem ter extraído os grupos funcionais situados nesta região.

O limite de detecção dos espectros de RMN CPMAS está em torno de $5 \%$ em massa, o que significa que a quantidade de lignina das amostras de eucalipto deve ser 
inferior a este valor. Verifica-se também que os sinais em 86 e 80 ppm apresentam mais intensos nas fibras de eucalipto, provavelmente devido a maior proporção de componente lignocelulósicos nas fibras oriundas de madeira dura, ou seja, de eucalipto. Entre os espectros das fibras de eucalipto, não se observou diferenças - fato que deve estar relacionado à quantidade de lignina e hemicelulose nessas fibras estar abaixo do limite de detecção da técnica devido ao pré-tratamentos, os quais foram submetidos essas fibras de eucalipto.

Tabela 3 - Atribuição dos picos aos diferentes carbonos de cada uma das biomoléculas das fibras de eucalipto e bagaço de cana de açúcar.

\begin{tabular}{|c|c|c|c|}
\hline \multicolumn{3}{|c|}{ Desvio químico ppm } & \multirow[b]{2}{*}{ Grupos de base } \\
\hline Identificação & $\begin{array}{l}\text { Cana de } \\
\text { açúcar }\end{array}$ & Eucalipto & \\
\hline 15 & 171 & - & $\begin{array}{l}\text { Grupos carbonilas de lignina e grupos } \\
\text { carboxila em hemicelulose. }\end{array}$ \\
\hline 14 & 157 & - & $\begin{array}{l}\text { Oxigênio substituinte dos carbonos (C-3 e C- } \\
\text { 4) dos anéis aromáticos. }\end{array}$ \\
\hline 13 & 150 & - & $\begin{array}{l}\text { Oxigênio substituinte dos carbonos (C-3 e C- } \\
\text { 4) dos anéis aromáticos. }\end{array}$ \\
\hline 12 & 145 & - & $\begin{array}{l}\text { Carbono C-4 do anel aromático da lignina } \\
\text { contendo grupos livres ligados. }\end{array}$ \\
\hline 11 & 131 & - & Carbono C-1 do anel aromático. \\
\hline 10 & 124 & - & Carbono aromático. \\
\hline 9 & 114 & - & $\begin{array}{l}\text { Carbonos C-2,C-5 e C- } 6 \text { carbonos do anel e } \\
\text { carbonos da cadeia lateral } \mathrm{sp}^{2} \text {. }\end{array}$ \\
\hline 8 & 102 & 102 & Carbono C-1 do anel aromático. \\
\hline 7 & 86 & 86 & $\begin{array}{l}\text { Sobreposição } \\
\text { hemicelulose; carbono } \text { C-4 de } \\
\text { amorfa. }\end{array}$ \\
\hline 6 & 81 & 80 & $\begin{array}{l}\text { Sobreposição de carbonos C-2,C-3 e C-5 em } \\
\text { celulose; alargamento da sobreposição de } \\
\text { carbonos C-2,C-3 e C-5 de hemiceluloses. }\end{array}$ \\
\hline 5 & 70 & 70 & $\begin{array}{l}\text { Sobreposição de carbonos C-2,C-3 e C-5 em } \\
\text { celulose; alargamento da sobreposição de } \\
\text { carbonos C-2,C-3 e C-5 de hemiceluloses. }\end{array}$ \\
\hline 4 & 72 & 72 & Carbonos C2, C3 e C5 de celulose. \\
\hline 3 & 62 & 62 & $\begin{array}{l}\text { Carbono C- } 6 \text { de celulose amorfa e Carbono } \\
\mathrm{N} \text {-alquila de lignina. }\end{array}$ \\
\hline 2 & 54 & - & Carbonos aril metoxila de lignina. \\
\hline 1 & 19 & - & Grupos acetatos em hemicelulose. \\
\hline
\end{tabular}




\subsubsection{Espectroscopia no Infravermelho}

Neste trabalho, foram obtidos espectros de absorção no infravermelho de fibras de eucalipto após diferentes pré-tratamentos, visando investigar as mudanças estruturais que ocorrem quando a fibra é pré-tratada com ácido e/ou xilanase. O espectro de bagaço de cana-de-açúcar in natura, ou seja, sem qualquer pré-tratamento, foi obtido para facilitar a identificação das bandas nos espectros de fibras de eucalipto. Além disso, foi também obtido o espectro de água para se verificar, a hidratação das fibras em função dos prétratamentos.

A Figura 30 apresenta os espectros para o bagaço de cana-de-açúcar in natura (BCA), bem como das fibras de eucalipto não pré-tratada com ácido e/ou xilanase (FENT) e, pré-tratadas somente com ácido (FETA), com ácido e xilanase (FETAE), somente com xilanase (FETE), com xilanase e ácido (FETEA). Observa-se nesses espectros, da Figura 30, que tanto as fibras de bagaço de cana-de-açúcar, quanto, as fibras de eucalipto estavam hidratadas e, apresentavam bandas associadas à celulose. Estas bandas são: em $896 \mathrm{~cm}^{-1}$, característica de regiões amorfa da celulose (CAO; TAN, 2006), resultante da vibração de estiramento no plano do anel sacarídeo e deformação em C-H (COSTA JR; MANSUR, 2008); em $1053 \mathrm{~cm}^{-1}$ associada ao estiramento de C-O; em $1160 \mathrm{~cm}^{-1}$ característica do estiramento de C-O-C em anéis piranoses e estiramento de $\mathrm{C}=\mathrm{O}$ em grupos alifáticos (muito comuns em madeira tratada) (DELBEN et al., 2006); em $1202 \mathrm{~cm}^{-1}$ associada à flexão de $\mathrm{OH}$ no plano de celulose do tipo I e II; em $1336 \mathrm{~cm}^{-1}$ correspondente a vibrações de $\mathrm{C}_{1}-\mathrm{O}$ em derivados de $\mathrm{S}$ e flexão de $\mathrm{CH}$ no plano de celulose do tipo I e II; em $1430 \mathrm{~cm}^{-1}$, característica de celulose cristalina, devido anéis aromáticos combinados com estiramento e deformação no plano de C-H (HUANG, 2011).

A partir da comparação das bandas nos espectros de fibras de eucalipto com diferentes pré-tratamentos, verifica-se que elas diminuem significativamente, possivelmente em decorrência dos pré-tratamentos sofridos, que reduziram os grupos funcionais referentes à celulose. Estes resultados podem, ser melhor observados na Figura 31, que compara as intensidades de absorção da banda em $1430 \mathrm{~cm}^{-1}$. Veja que a intensidade absorbância decresce em função dos pré-tratamentos, sendo a menor 
intensidade de absorbância verificada para as fibras pré-tratadas com xilanase e ácido (FETEA).

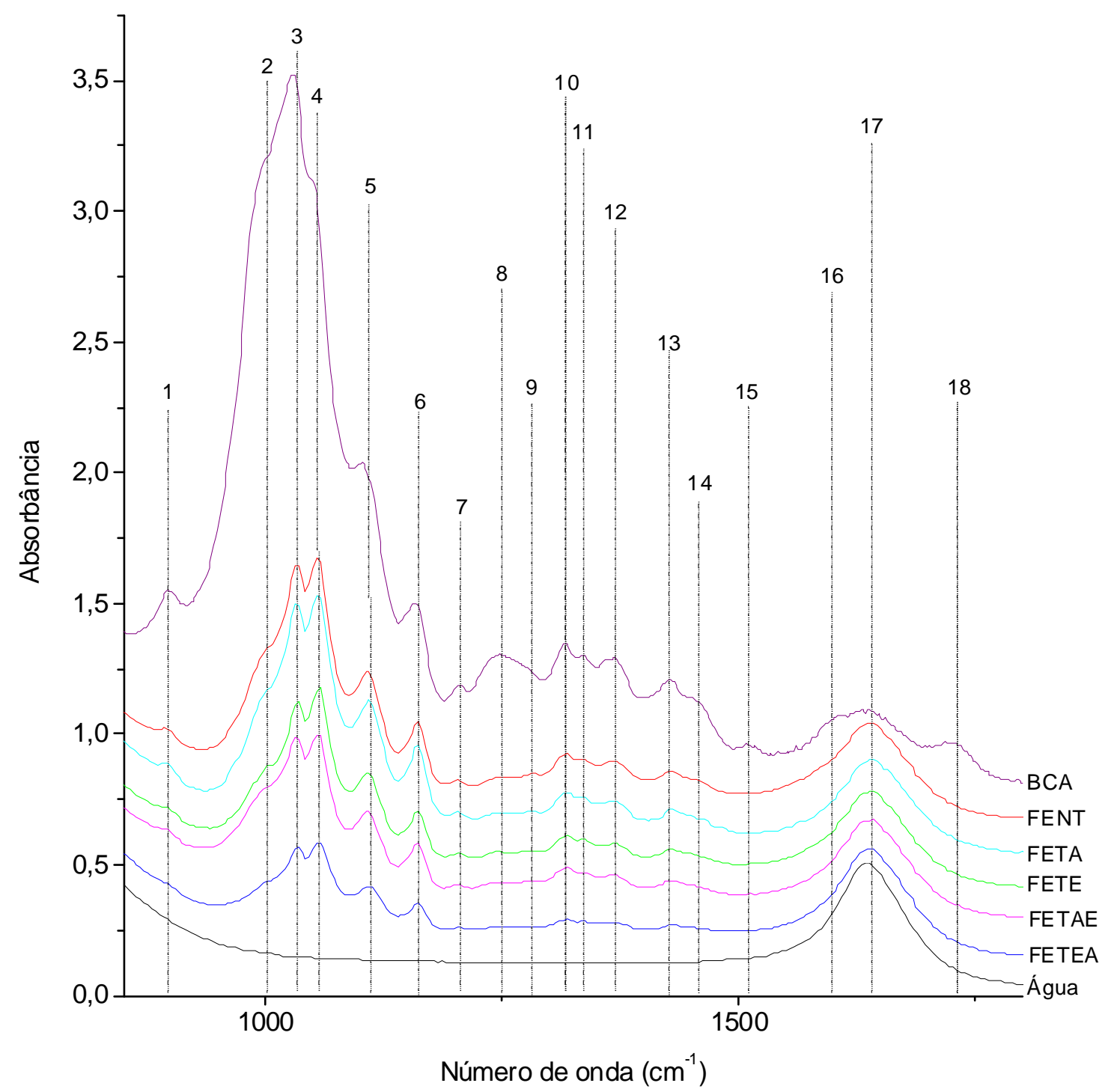

Figura 30 - Espectros FTIR de: Água; (FETEA) Fibra de eucalipto pré-tratada com enzima e ácido; (FETAE) Fibra de eucalipto pré-tratada com ácido e xilanase; (FETE) Fibra de eucalipto pré-tratada com xilanase; (FETA) Fibra de eucalipto pré-tratada com ácido; (FENT) Fibra de eucalipto não pré-tratada com ácido e/ou xilanase; (BCA) Bagaço de cana de açúcar in natura (sem qualquer pré-tratamento). 


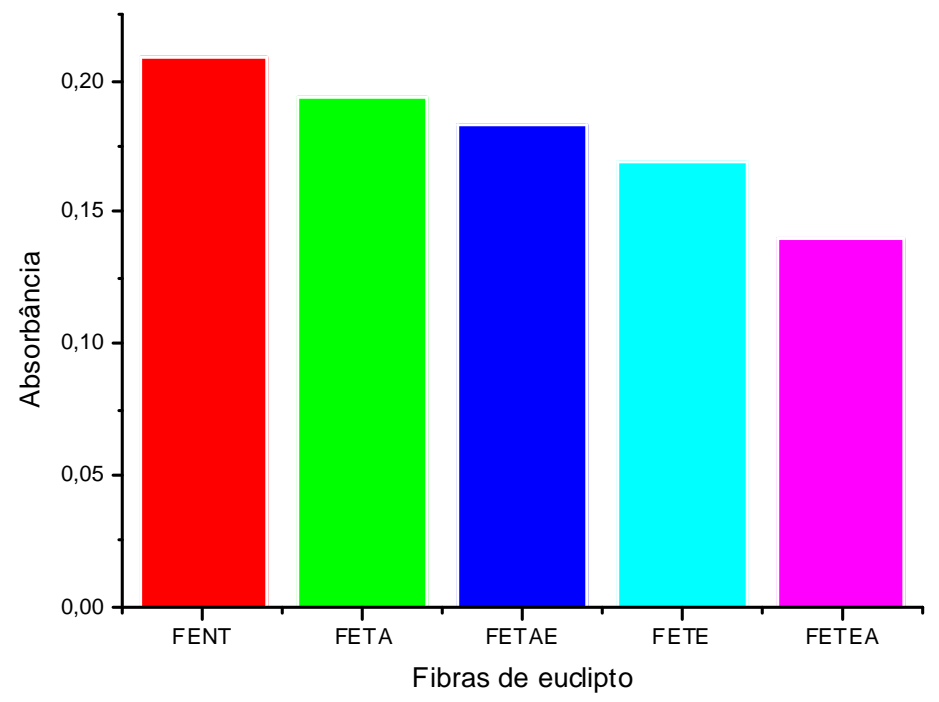

Figura 31 - Comparação de absorbância da banda em $1430 \mathrm{~cm}^{-1}$ observada nos espectros de fibras de eucalipto apresentada na Figura 30.

Nos espectros da Figura 30, foi também observada, uma banda característica de hemicelulose em $1247 \mathrm{~cm}^{-1}$ referente a grupos acetil. Embora pouco visível nas fibras de eucalipto, essa banda apresentou um decréscimo em função dos pré-tratamentos, sendo mais acentuado no pré-tratamento xilanases-ácido. Isso provavelmente é decorrente principalmente da ação das enzimas, uma vez que xilanases degradam xilana (grupo de hemiceluloses) facilitando a liberação da lignina (LORENTZ, 2005). Além disso, se compararmos os espetros FETA e FETE, observa-se uma maior redução na banda de hemicelulose, como também nas outras bandas, no espetro da fibra pré-tratada somente com xilanase, ou seja, FETE - o que reforça a provável eficácia das enzimas xilanases no pré-tratamento das fibras.

Além da celulose e hemicelulose, os espectros da Figura 30 apresentaram também bandas típicas de lignina; são elas: em $1034 \mathrm{~cm}^{-1}$ atribuído à deformação de C-O em alcoóis primários, estiramento de $\mathrm{C}=\mathrm{O}$ não-conjugado e a deformação planar de $\mathrm{C}-\mathrm{H}$ em unidade guaiacila (PANDEY, 1999); em $1109 \mathrm{~cm}^{-1}$ devida ao estiramento assimétrico em fase do anel; em $1281 \mathrm{~cm}^{-1}$ atribuída à respiração de anéis guaiacila e estiramento de $\mathrm{C}=\mathrm{O}$; em $1318 \mathrm{~cm}^{-1}$ devida à condensação de unidades de guaiacila e siringila (estiramento e flexão de unidade de siringila e $\mathrm{CH}_{2}$ ); em $1370 \mathrm{~cm}^{-1}$ associada ao estiramento de C-H alifático em metil e de $\mathrm{OH}$ em fenol (SHEN, 2010); em $1509 \mathrm{~cm}^{-1}$ atribuída vibrações de anéis aromáticos; em $1595 \mathrm{~cm}^{-1}$ e $1638 \mathrm{~cm}^{-1}$ decorrentes a 
estiramento conjugado de $\mathrm{C}=\mathrm{O}$ em anéis aromáticos (SILVA et al.,1998; SHEN et al., 2010). Pode-se ainda verificar uma banda próxima de $1000 \mathrm{~cm}^{-1}$ devido à flexão $=\mathrm{C}-\mathrm{H}$, característica de éteres alifáticos e aromáticos, no entanto, não é característica de ligninas (LABAT, 2008). Com exceção da banda $1638 \mathrm{~cm}^{-1}$, que também está relacionada à molécula de água (espectro água), observa-se nos espectros FETE, FETA, FETEA e FETAE que todas as outras bandas relacionadas a estruturas de lignina, sofreram reduções com os pré-tratamentos. O pré-tratamento enzimático (com xilanase) e os combinados, ou seja, ácido-xilanase ou xilanase-ácido foram os que apresentaram maior efeito na redução de grupos funcionais ligados a lignina e a hemicelulose.

O pré-tratamento somente com ácido, embora agressivo, que sugere uma maior redução de hemicelulose e lignina nas fibras, não se mostrou tão eficaz se comparado aos outros pré-tratamentos. Além disso, em relação ao espectro FENT, o espectro referente ao pré-tratamento somente com ácido (FETA) não apresentou diferenças na intensidade de absorção. Porém, quando o pré-tratamento ácido foi combinado com o pré-tratamento enzimático (com xilanase), observou-se uma redução na absorção, mostrando assim que processos de pré-tratamentos combinados são mais eficientes.

Nos espectros da Figura 30, é possível se verificar também uma variação relativa na intensidade de absorbância entre as bandas de fibra de cana de açúcar e eucalipto, que é devido aos pré-tratamentos, como também, às diferentes proporções de constituintes poliméricos presentes nas mesmas (DELBEN et al., 2006). A posição de todas as bandas de celulose, hemicelulose e lignina observada nos espectros da Figura 30, são resumidas na tabela 4. Comparando essas posições, verifica-se que algumas bandas de absorção das fibras de eucalipto se deslocam para maiores números de onda - fato que pode estar relacionado com a re-orientação das moléculas em função dos pré-tratamentos. 
Tabela 4 - Resumo das bandas de vibrações no infravermelho observadas em fibras de cana de açúcar e eucalipto.

\begin{tabular}{|c|c|c|c|}
\hline \multirow[b]{2}{*}{ Identificação } & \multicolumn{2}{|c|}{$\begin{array}{l}\text { Número de onda } \\
\left(\mathrm{cm}^{-1}\right)\end{array}$} & \multirow[t]{2}{*}{ Grupos de base e modos vibracionais } \\
\hline & $\begin{array}{l}\text { Cana de } \\
\text { açúcar }\end{array}$ & Eucalipto & \\
\hline 18 & 1723 & - & Deformação axial de $\mathrm{C}=\mathrm{O}$. \\
\hline 17 & 1638 & 1638 & $\begin{array}{l}\text { Estiramento conjugado de } \mathrm{C}=\mathrm{O} \text { em anéis } \\
\text { aromáticos. }\end{array}$ \\
\hline 16 & 1595 & - & $\begin{array}{l}\text { Estiramento conjugado de } \mathrm{C}=\mathrm{O} \text { em anéis } \\
\text { aromáticos. }\end{array}$ \\
\hline 15 & 1509 & - & Vibrações de anéis aromáticos. \\
\hline 14 & 1446 & - & Deformação assimétrica em $\mathrm{CH}_{3}$ \\
\hline 13 & 1424 & 1430 & $\begin{array}{l}\text { Característica de celulose } \\
\text { Deformação no plano de C-H com } \\
\text { estiramento do anel aromático. }\end{array}$ \\
\hline 12 & 1366 & 1370 & $\begin{array}{l}\text { Estiramento de } \mathrm{C}-\mathrm{H} \text { alifático em metil e de } \\
\mathrm{OH} \text { em fenol. }\end{array}$ \\
\hline 11 & 1334 & 1336 & $\begin{array}{l}\text { Vibrações de } \mathrm{C}_{1}-\mathrm{O} \text { em derivados de } \mathrm{S} \text { e } \\
\text { flexão de } \mathrm{CH} \text { no plano de celulose do tipo I e } \\
\text { II. }\end{array}$ \\
\hline 10 & 1316 & 1318 & $\begin{array}{l}\text { Estiramento de } \mathrm{O}-\mathrm{H} \text {, condensação de } \\
\text { unidades de guaiacila e siringila, estiramento } \\
\text { e flexão de unidade de siringila e } \mathrm{CH}_{2} \text {. }\end{array}$ \\
\hline 9 & 1281 & 1281 & $\begin{array}{l}\text { Respiração de anéis guaiacila e estiramento } \\
\text { de } \mathrm{C}=\mathrm{O} \text {. }\end{array}$ \\
\hline 8 & 1247 & 1247 & Grupos acetil. \\
\hline 7 & 1202 & 1202 & $\begin{array}{l}\text { Flexão de } \mathrm{OH} \text { no plano de celulose do tipo I e } \\
\text { II. }\end{array}$ \\
\hline 6 & 1157 & 1160 & $\begin{array}{l}\text { Estiramento de } \mathrm{C}-\mathrm{O}-\mathrm{C} \text { em anéis piranoses e } \\
\text { estiramento de } \mathrm{C}=\mathrm{O} \text { em grupos alifáticos. }\end{array}$ \\
\hline 5 & 1103 & 1109 & Estiramento assimétrico em fase do anel. \\
\hline 4 & 1053 & 1053 & Estiramento de $\mathrm{C}-\mathrm{O}$. \\
\hline 3 & 1034 & 1034 & $\begin{array}{l}\text { Deformação de } \mathrm{C}-\mathrm{O} \text { em alcoóis primários, } \\
\text { estiramento de } \mathrm{C}=\mathrm{O} \text { não conjugado e } \\
\text { deformação planar de } \mathrm{C}-\mathrm{H} \text { em unidade } \\
\text { guaiacila. }\end{array}$ \\
\hline 2 & 1000 & 1000 & Flexão de =C-H. \\
\hline 1 & 896 & 896 & $\begin{array}{l}\text { Estiramento no plano do anel sacarídeo e } \\
\text { deformação em C-H. }\end{array}$ \\
\hline
\end{tabular}




\subsubsection{Microscopia óptica campo de claro}

A microscopia óptica campo claro é uma técnica muito comum na investigação de materiais biológicos. Neste trabalho, a técnica foi empregada para a visualização das fibras de eucalipto, visando conhecer a morfologia das fibras e verificar mudanças, que podem ocorrer com os pré-tratamentos. As imagens das fibras de eucalipto com diferentes pré-tratamentos são mostradas na Figura 32. As Figuras 32a, 32b e 32d são imagens de transmissão de luz de uma lâmpada de halogênio e as Figuras 32c, 32e, 32f, 32g e 32h são de fluorescência, que foram excitadas com luz de uma lâmpada de mercúrio, porém, filtros adequados, permitiram a excitação entre os comprimentos de onda entre 350-390 nm. As imagens foram detectadas com uma câmera CCD.

Nas imagens da Figura 32, observa-se que cada fibra de eucalipto tem um aspecto um tanto irregular e complexo, o que é característico de uma imagem de transmissão que, favorece efeitos de lente óptica, devido ao índice de refração das fibras. Uma análise da geometria e dimensão das fibras fica comprometida por esse efeito. No entanto, verificase que as fibras de eucalipto são praticamente transparentes, apresentando regiões opacas (indicados pelas setas na Figura 32a) que, provavelmente, deve estar relacionado com um arranjo organizado e periódico das moléculas de celulose, nesta região da fibra (CORRÊA, 2010; SANCHEZ et al., 2010). As outras regiões das fibras (entre as regiões opacas), provavelmente devido à ausência de um arranjo organizado das moléculas dos compontentes lignocelulósicos, são basicamente transparentes a passagem de luz (Figura 32b). As regiões opacas são chamadas, neste trabalho, de estrangulamento ou empescoçamento.

A transparência das fibras podem ser melhor visualizadas, no ponto em que elas se cruzam (indicado por seta na Figura 32b). E quando uma fibra se sobrepõe outra, observase que as intensidades de fluorescência se somam (Figura 32c). A presença de fibrilas e outras estruturas, pode ser observadas na Figura 32d. Além disso, nestas imagens de fluorescência, observa-se também que, apesar dos pré-tratamentos, a fluorescência das fibras é bastante intensa e praticamente composta por uma luz branca, conforme demonstrado pelo espectro largo de emissão da Figura 27a. Efeitos associados ao índice de refração são agora minimizados, nas imagens de florescência. Pode-se ver que as fibras possuem geometria tubular e alongada, com emissão predominante nas paredes. As 
dimensões variam em média de 8 a $12 \mu \mathrm{m}$ de diâmetro e alguns milímetros de comprimento. A emissão é maior na parte amorfa, correspondente aos estrangulamentos.

Sabe-se que as regiões cristalinas das fibras, ou seja, regiões onde não há passagem de luz, devido ao arranjo organizado e periódico das moléculas, são insolúveis em ácidos, nas condições em que estes são empregados (SANCHEZ et al., 2010). Isso pode ser por causa da inacessibilidade que as mesmas apresentam pela alta organização das moléculas na sua estrutura. Por outro lado, a desorganização natural das moléculas de celulose nas regiões amorfas (regiões onde a luz incidente atravessa os seus átomos/moléculas constituintes sem qualquer dificuldade), favorece a acessibilidade dos ácidos e, conseqüentemente, a hidrolise das cadeias de celulose, presentes nestas regiões (SANCHEZ et al., 2010). Assim, o isolamento de fibras de celulose, deve ser facilitado, pela cinética da hidrólise mais rápida, apresentada pelas regiões amorfas (regiões transparentes), em relação, às regiões cristalinas.

$\mathrm{Na}$ Figura 32c podem ser observadas dobras nas fibras de eucalipto. A lignina confere rigidez à parede celular, na madeira age como ligação entre as células, gerando uma estrutura resistente ao impacto, à compressão e à dobra (SANCHEZ et al., 2010). Sendo assim, entende-se que a presença de dobras nas fibras de eucalipto seja resultado do processo do pré-tratamento que essas fibras sofreram. Provavelmente, o pré-tratamento reduziu a concentração de lignina nas fibras, tornando-as mais flexíveis.

$\mathrm{Na}$ Figura 32d verifica-se fibras contidas no plano de fundo da imagem de FETA. Essas fibras são da escala de nano e, são formadas por longas cadeias de celulose, organizadas no sentido da fibra, logo, são conhecidas como fibrilas de celulose ou nanofibras. Geralmente elas possuem diâmetro de 10 a $30 \mathrm{~nm}$ e são resultantes do empacotamento de 30 a 100 cadeias de celulose estendidas (LEPPÄNEN, 2009). Para se ter acesso a essas fibrilas, é necessário desconstruir a parede celular da fibra. Como já vimos, essa desconstrução é alcançada por meio de métodos de pré-tratamentos. Sendo assim, a presença de fibrilas deve ter sido provocada pelo pré-tratamento aplicado as fibras de eucalipto, indicando que o pré- tratamento agiu de forma eficiente no processo de deslignificação. Nas imagens das outras fibras (FENT, FETAE, FETE e FETEA), não foi observado essas fibrilas. 


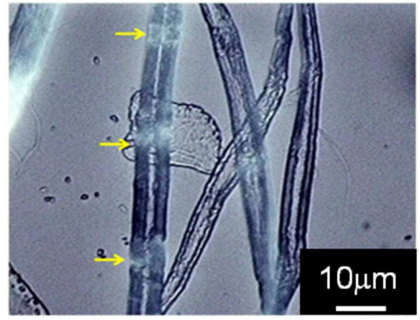

(a)

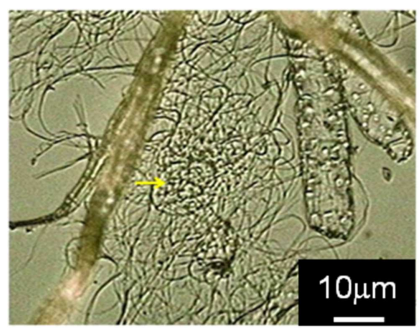

(d)

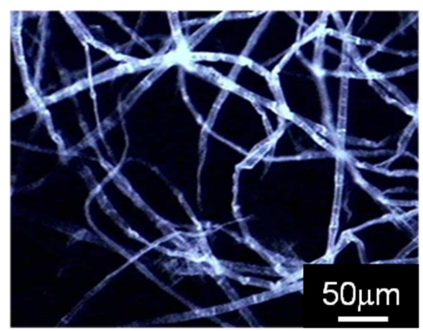

$(\mathrm{g})$

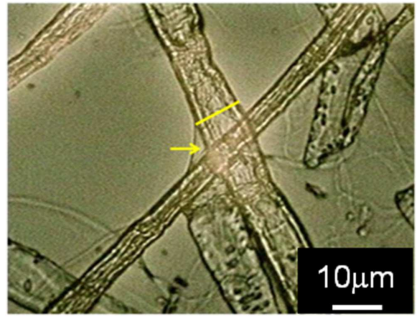

(b)

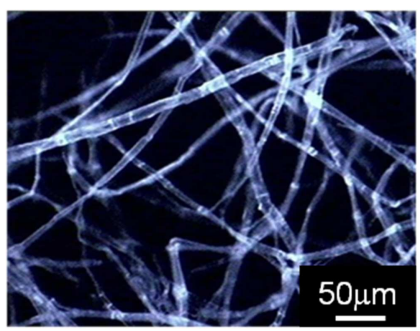

(e)

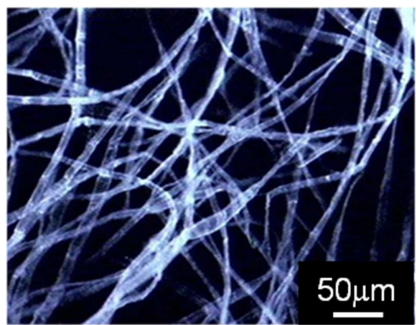

(h)

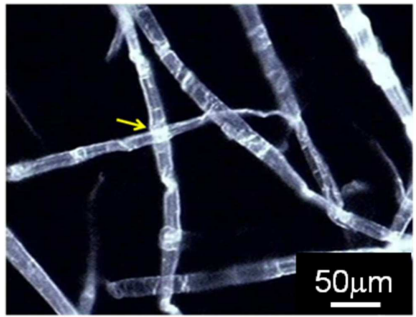

(c)

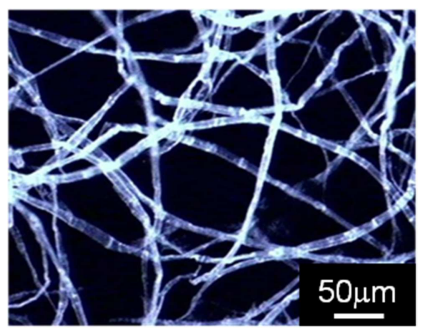

(f)

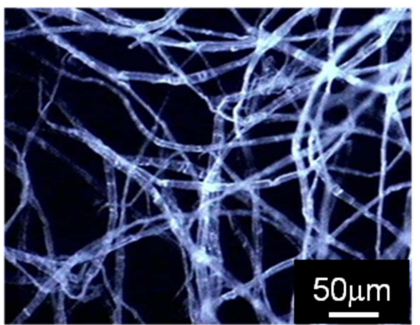

$(\mathrm{g})$

Figura 32 - Imagens de transmissão de fibra: (a) setas indicando as regiões de estrangulamento empescoçamento na FETA; (b) mostrando superposição das FETA e (d) setas indicando as fibrilas (ou nanofibras) no plano de fundo da imagem das FETA; Imagens de fluorescência: (c) mostrando a soma das intensidades de fluorescência devido à sobreposição de FETEA; (e) FENT; (f) FETA; (g) FETAE; (h) FETE e (i) FETEA.

Da comparação das fibras não pré-tratadas (Figura 32e) e as pré-tratadas diferentemente com ácido e/ou xilanase (Figura 32f, Figura 32g, Figura 32h e Figura 32i), não observou-se diferenças morfológicas e/ou mudanças estruturais visíveis entre elas. Para tal, foi implementado no presente trabalho, a técnica de microscopia eletrônica de varredura por emissão de campo e microscopia de fluorescência confocal por varredura a laser (CLSM). Essas técnicas possuem um poder de resolução muito grande, sendo possível obter informações menores do que micrometros. Os resultados dos experimentos, nos quais foram empregadas estas técnicas, neste trabalho, são apresentadas nos tópicos 4.1.6, 4.1.7, 4.1 .8 e 4.1.9. 


\subsubsection{Microscopia eletrônica de varredura por emissão de campo}

A microscopia eletrônica é uma técnica muito útil na investigação de fibras lignocelulósicas. Essa ferramenta poderosa é capaz de fornecer informações morfológicas e topográficas necessárias para se analisar a superfície dessas fibras. Neste trabalho, a técnica foi empregada para se verificar mudanças estruturais visíveis na superfície das fibras de eucalipto causadas pela ação química e/ou biológica durante os processos de pré-tratamentos. As imagens de microscopia eletrônica dessas fibras são apresentadas na Figura 33.

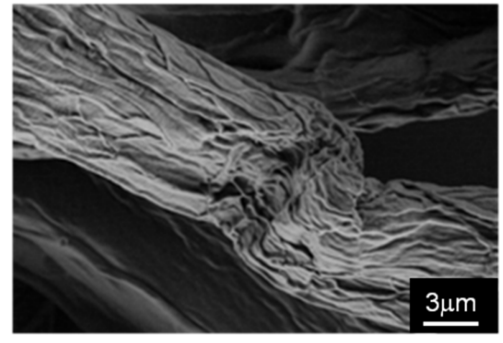

(a)

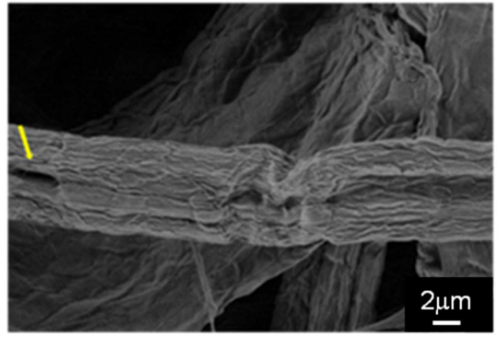

(c)

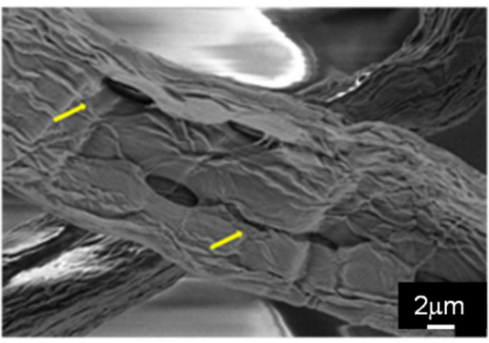

(b)

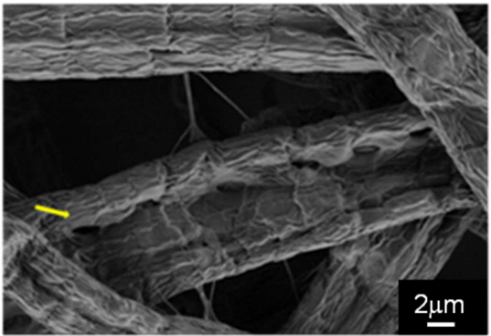

(d)

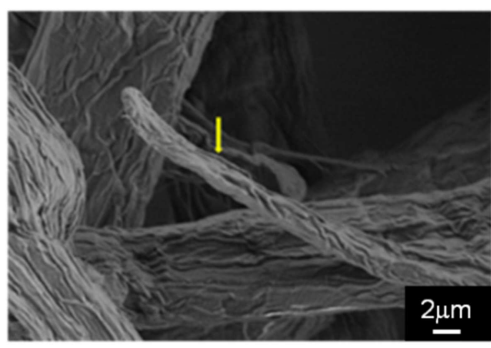

(e)

Figura 33 - Fibras de eucalipto: (a) não pré-tratada com ácido e/ou xilanase mostrando região de estrangulamento ou empescoçamento (FENT); (b) pré-tratada com ácido (FETA) mostrando os orifícios; (c) pré-tratada com ácido e enzima (FETAE) mostrando o desgaste nos orifícios; (d) Pré-tratada com enzima (FETE), mostrando desgaste maior 
nos orifícios e, (e) pré-tratada com enzima e ácido (FETEA) mostrando o desfibrilamento.

Nas imagens das fibras de eucalipto, apresentadas na Figura 33, alguns pontos devem ser notados em relação à superfície dessas fibras. Em primeiro lugar, é importante observar que as fibras não apresentaram uma superfície lisa e homogênea. Nota-se que a superfície dessas fibras é bastante irregular, coberta por reentrâncias e saliências.

Outro ponto a ser observado, nas fibras, é a presença de orifícios na superfície. Esses orifícios são denominados canais de pontuação (ou pits) e, estão presentes em toda a extensão das fibras (FERGEL; WEGENER, 1984; MARTINS; MATTOSO; PESSOA, 2009). A condução e distribuição de solução aquosa bem como a troca de conteúdo celular dentro da planta são possíveis devido à presença destes orifícios (DONALDSON, 2001). Da comparação da imagem das fibras não tratadas (Figura 33a) com as imagens das fibras que sofreram algum tipo de pré-tratamento (Figura 33b, Figura 33c, Figura 33d e Figura 33e), verifica-se um número maior desses orifícios na superfície das fibras prétratadas, principalmente na fibra pré-tratada somente com enzima. Verifica-se também que a superfície nas regiões dos orifícios dessas fibras se apresenta desgastada, que provavelmente deve ter ocorrido com a remoção da lignina, provocando o desfibrilamento. Como pode ser verificado nas imagens da Figura 33, esse desgaste apresenta-se mais acentuado nas fibras pré-tratadas somente com enzimas (Figura 33d).

A realização de uma investigação minuciosa das imagens, onde a aplicação de técnicas de processamento de imagens, provavelmente poderá fornecer informações importantes e precisas acerca dos efeitos dos pré-tratamentos e da degradação enzimática observados nas fibras, como também de outras mudanças nos padrões superficiais, ocasionados pelos processos de pré-tratamentos. Esta investigação envolve um número muito grande de imagens. Logo, este é um ponto que ficou em aberto no presente trabalho, sendo necessária a realização experimentos posteriores. Porém, como um dos focos foi uma caracterização óptica por fluorescência em alta resolução, estas imagens servirão como referência para os próximos tópicos.

\subsubsection{Microscopia confocal de fluorescência varredura a laser}


A fluorescência, conforme visto no tópico 4.1.1, é uma fonte de informações estruturais, fisiológicas e químicas de fibras lignocelulósicas. Com um microscópio confocal de fluorescência varredura a laser (CLSM) estas informações podem ser tanto espacial, como espectral e temporalmente resolvidas. Neste trabalho, essa técnica foi usada para aumentar o contraste das imagens das fibras, construir imagens tridimensionais 3D, distinguir elementos e obter informações sobre possíveis mudanças estruturais de fibras de eucalipto pré-tratadas (FETA, FETAE, FETE, FETEA) e não prétratadas com ácido e/ou enzima (FENT).

As Figuras 34a e 34b ilustram duas imagens que exemplificam as potencialidades da técnica CLSM para o caso de uma fibra de eucalipto isolada, que é principalmente devido à emissão da lignina. Um corte confocal específico da fibra é mostrado na Figura 34a, o que demonstra que a lignina se concentra nas paredes da célula (fibra). Já a seta mostra a seção transversal da mesma fibra. Este resultado indica que as fibras possuem geometria tubular com diâmetro em torno de $10 \mu \mathrm{m}$ contendo regiões de estrangulamentos. Já a Figura 34b foi obtida pela superposição de cada plano confocal, que reproduz uma característica tridimensional. O corte da região de estrangulamento (ou emprescoçamento) nessa imagem também é visualizado a partir do corte transversal da fibra. Esta região é mais estreita e não oca (seta na Figura 34b).

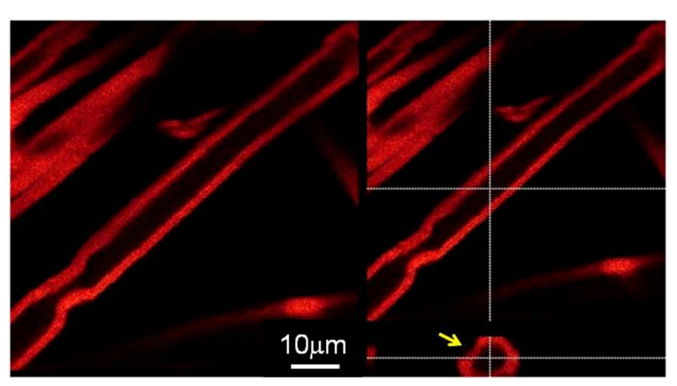

(a)

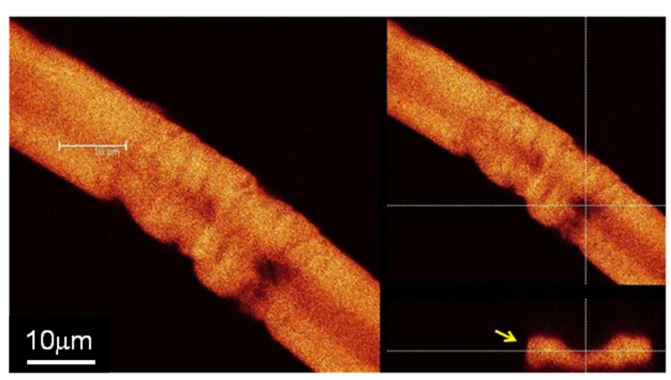

(b) 
Figura 34 - (a) Imagens CLSM da fibra de eucalipto sem pré-tratamento ácido e/ou enzimático (FENT) mostrando o corte transversal que evidencia que a fibra é oca e tubular; (b) Imagens CLSM da superfície da fibra de eucalipto pré-tratada com ácido e enzima (FETAE) e corte transversal da região de estrangulamento (ou empescoçamento), mostrando que esta região é mais estreita. Escala das imagens $=10 \mu \mathrm{m}$.

É interessante assinalar que o comprimento de onda do laser utilizado nas imagens das Figuras 34a e 34b foi de $405 \mathrm{~nm}$. De acordo com os espectros da Figura 28b, esse comprimento de onda parece inadequado para excitar as fibras estudadas nesse trabalho que têm máximo do espectro de excitação em torno de $312 \mathrm{~nm}$. No entanto, mesmo nessas condições e com utilizando condições de baixas potências do laser (10\% da potência nominal), a microscopia confocal ainda consegue reproduzir boa qualidade e resolução das fibras. Estes aspectos serão apresentados e discutidos com mais detalhes no próximo tópico.

Uma série de investigações tem evidenciado que, a distribuição da lignina pode ser altamente variável dentro de uma única amostra de fibra (DONALDSON, 2001). Geralmente, há uma lamela altamente lignificada contendo uma predominância de unidades guaiacila e uma parede secundária menos lignificada composta por uma mistura de unidades guaiacila e siringila (XU et al, 2006). Esses tipos de unidades estruturais da lignina nas fibras de eucalipto podem, frequentemente, ser distinguidos com base na função da célula (suporte estrutural versus condução de água - o primeiro a favor de uma parede secundária menos lignificadas e o último a favor de uma parede secundária mais lignificada) (DONALDSON; LAUSBERG, 1998). Além disso, diferenças na intensidade da fluorescência da imagem também podem fornecer indícios quanto à distribuição de lignina na fibra, ou seja, a concentração de lignina reflete no aumento ou a diminuição na intensidade da fluorescência (DONALDSON; LAUSBERG, 1998). Entretanto, nesse trabalho, isso não foi possível de se observado.

Apesar da técnica de microscopia confocal de fluorescência ser uma técnica extremamente poderosa na detecção de imagens de alta resolução, não notamos nenhuma diferença significativa entre as imagens CLSM. Além disso, a qualidade dos resultados das imagens CLSM de tecidos vegetais é dependente de inúmeras variáveis, como por exemplo da absortividade da molécula de lignina, que é bastante sensível a diferentes fatores estruturais (DONALDSON; LAUSBERG, 1998). Nesse sentido, alguns problemas associados ao uso do microscópio confocal de fluorescência varredura a laser na investigação de tecidos vegetais tem sido apontados na literatura (KITIN et al., 2000). Um dos principais problemas é a escolha adequada de corantes fluorescentes e outro, o 
estabelecimento de técnicas para induzir a fluorescência de componentes específicos do tecido em estudo (CASTELLAN, 1994). Assim, a fim de melhorar a qualidade das imagens de fluorescência das fibras de eucalipto, foi implementado nos experimentos a incorporação de um polímero que contém unidades emissoras de luz, o PTHT-PPV. Os efeitos dessa incorporação nas imagens são apresentados no próximo tópico.

\subsubsection{Incorporação de polímero luminescente solúvel em água}

A Figura 35 compara os espectros de excitação (curvas azuis) e de fluorescência (curvas verdes) para a lignina e o PTHT-PPV ambos dissolvidos em solução de água, bem como para uma fibra de eucalipto na faixa espectral UV-Vis. A excitação do laser de maior energia (identificada na figura pela linha vermelha pontilhada em $405 \mathrm{~nm}$ ) e faixa de detecção típica do CLSM (barra cinza) também é exibida para comparação. Veja que os comprimentos de onda de excitação para a lignina e fibras lignocelulósicas estão praticamente fora de um intervalo de excitação/detectção do CLSM (405 nm $<\lambda<800$ $\mathrm{nm})$, dificultando a caracterização da fibra com esta poderosa ferramenta óptica. Veja também, que o comprimento de onda de máxima exitação do PTHT-PPV corresponde ao comprimento de onda do laser usado neste trabalho e, a faixa de emissão da fluorescência do PTHT-PPV, observável via CLSM. Sendo, portanto, interessante a incorporaçao de um polímero altamente fluorescente como o PTHT-PPV, estudar sua viabilidade para aumentar as potencialidades de caracterização óptica pela técnica CLSM de substratos lignocelulósicos. Além disso, o estudo da interação de um material polimérico com a parede celular vegetal é de grande interesse para aplicações tecnologicas. Nesse caso, o PTHT-PPV é um polieletrólito, com carga positiva, que pode interagir de forma distinta com a parede celulósica, dependendo do pré-tratamento utilizado. Além disso, o PTHTPPV pode ser convertido parcialmente em um polímero conjugado semicondutor, o poli(p-fenileno vinileno) ou PPV, através de tratamento térmico $>100{ }^{\circ} \mathrm{C}$ ou irradiação de luz (MARLLETA, 2001; BORGES,2005), com emissão na região espectral amareloverde do visível. 


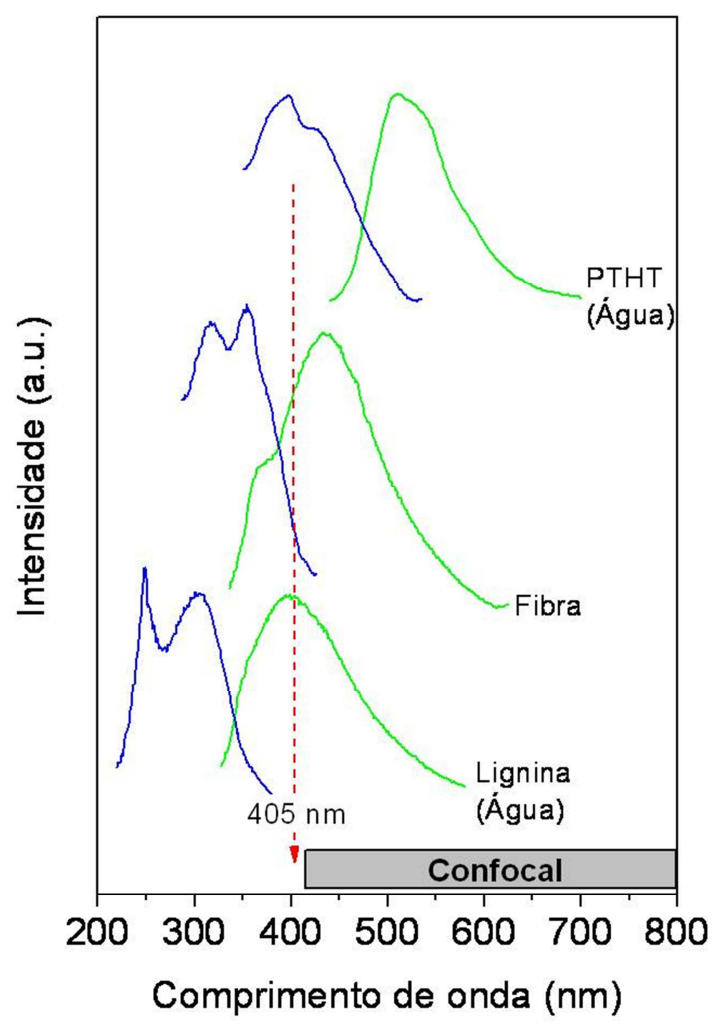

Figura 35 - Comparação de espectros de excitação (azul) e emissão (verde) do PTHT-PPV, fibra lignocelulósica e lignina mostrando a faixa de observação (barra cinza) via microscopia cofocal de fluorescência varredura laser. Os espectros em azul correspondem à excitação e os espectros em verde a emissão. A linha vermelha pontilhada identifica o comprimento de onda do laser utilizado em nosso trabalho.

Na Figura 35, as bandas nos espectros de excitação da lignina diluida em água (pH = 9) estão relacionadas às transições ópticas para $\lambda<330 \mathrm{~nm}$, de grupos cromóforos aromáticos polifenil (CASTELLAN, 1994). Foi constatado que a lignina proveniente de várias fontes ou de diferentes estruturas, comporta-se como se contivesse um único cromóforo. Depois de processos de transferência de energia, a excitação migra para uma estrutura específica que atua como dissipador de energia, como o cinamil álcool e o fenilcoumarina (ALBINSSON et al., 1999), a partir do qual a fluorescência é emitida em torno do comprimento de onda de $400 \mathrm{~nm}$. A excitação máxima, fica em torno de $350 \mathrm{~nm}$, e a máxima emissão, centrada próximo a $425 \mathrm{~nm}$. Além das diferenças entre os espectros de lignina e de fibra, os resultados mostram que a emissão geral da fibra é devido principalmente à componente lignina residual da fibra (CASTELLAN et al., 2007). 
Dos resultado anteriores, fica claro que existe a necessidade de adicionar um cromóforo sobre as fibras com as características do PTHT-PPV visando a melhora na caracterização estrutural das fibras que serão, por exemplo, degradadas em açucares menores para a geração de bioetanol de segunda geração.

Neste trabalho com as fibras de eucalipto, foi testado o PTHT-PPV em todas as fibras de eucalipto que sofreram diferentes pré-tratamentos (FENT, FETA, FETAE, FETE e FETEA). Aspecto da incorporação do PTHT-PPV à parede lignocelulósica será tratada nos próximos parágrafos. A comparação entre imagens de microscopia de fluorescência convencional (campo claro) de fibras FENT contendo ou não PTHT-PPV podem ser visualizadas, em imagens das fibras apresentadas na Figura 36. Nesse caso, uma gota da solução aquosa de PTHT-PPV $\left(0,5\right.$ g. $\left.\mathrm{L}^{-1}\right)$ foi espalhada sobre parte da superfície contendo as fibras e a imagem foi realizada após a secagem da mesma. A intensidade da luz de excitação é a mesma nas duas condições e, foi ajustada para não saturar a câmera CCD utilizada. Pode-se observar que, a intensidade de emissão das fibras contendo PTHT-PPV é muito maior, proporcionado pelas condições ótimas de excitação e pela sua maior eficiência de emissão. Além disso, pode-se ver, apesar da baixa resolução, que as fibras de eucalipto foram totalmente recobertas pelo polímero.

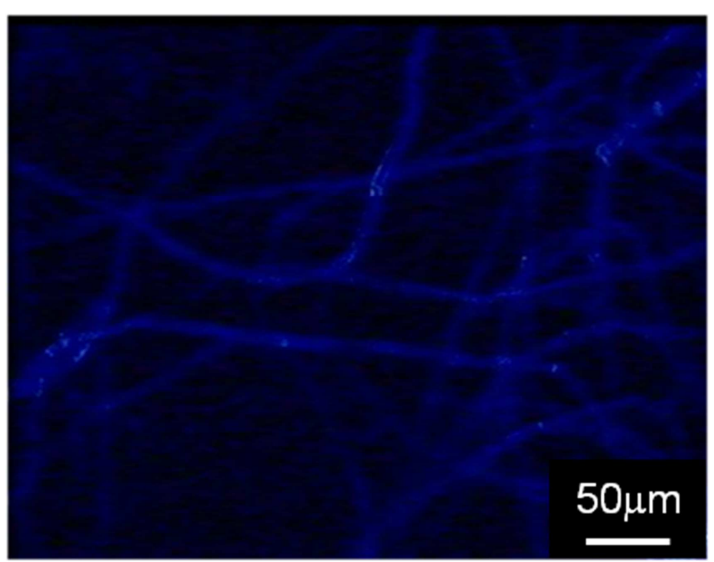

(a)

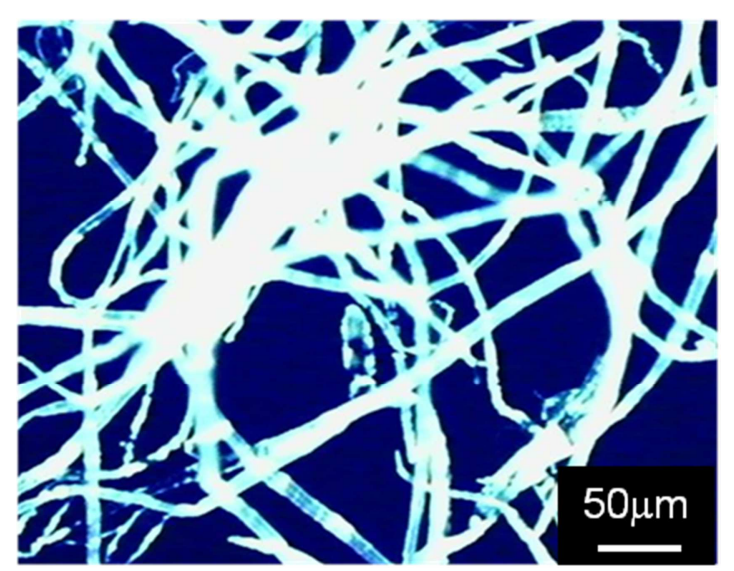

(b)

Figura 36 - Imagens de fluorescência de fibras de eucalipto (a) sem PTHT-PPV; (b) com PTHT-PPV.

As imagens de fibras isoladas FETE e FENT contendo PTHT-PPV são mostradas nas Figuras 37a e 37b, permitindo a visualização da estrutura com maior resolução, fornecendo informações detalhadas da superfície das fibras. Nessas imagens de fluorescência, observa-se que o PTHT-PPV foi incorporado ao longo da superfície das 
fibras de forma homogênea, o que pode ser visto pela maior intensidade da fluorescência das paredes (setas). A grande diferença entre a intensidade de emissão da lignina (baixa) e do PTHT-PPV (alta) permitiu a obtenção de um contraste das regiões externas (superfície) e interna da parede celular. Verifica-se que a região externa (superfície da fibra) apresentou fluorescência bastante intensa, enquanto que a região interna (dentro da fibra), fluorescência menos intensa. É interessante notar que o PTHT-PPV incorporou-se nas paredes externas e internas na fibra FENT (Figura 37b), mas não da fibra pré-tratada FETE, indicando que a solução aquosa difundiu-se para o seu interior através dos orifícios, permitindo a cobertura integral da parede interna com o polímero. Isso é indicação de que estas fibras encontram-se ocas em seu interior. O fato de o PTHT-PPV depositar no interior de apenas em algum tipo de fibra merece um estudo a parte, o que será feito na seção 4.2. Já que o PTHT-PPV cobriu também as paredes internas de algumas fibras de eucalipto não pré-tratada com ácido e/ou xilanase (Figura 37b). A imagem do corte transversal do lado direito da fibra de eucalipto não pré-tratada com ácido e/ou xilanase confirma a característica estrutural tubular e oca dessas fibras.

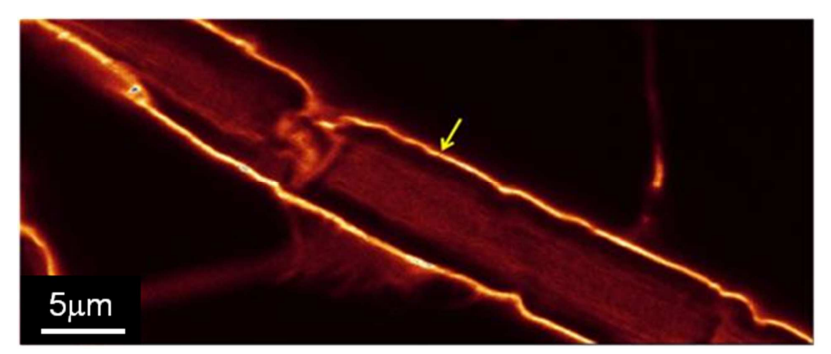

(a)

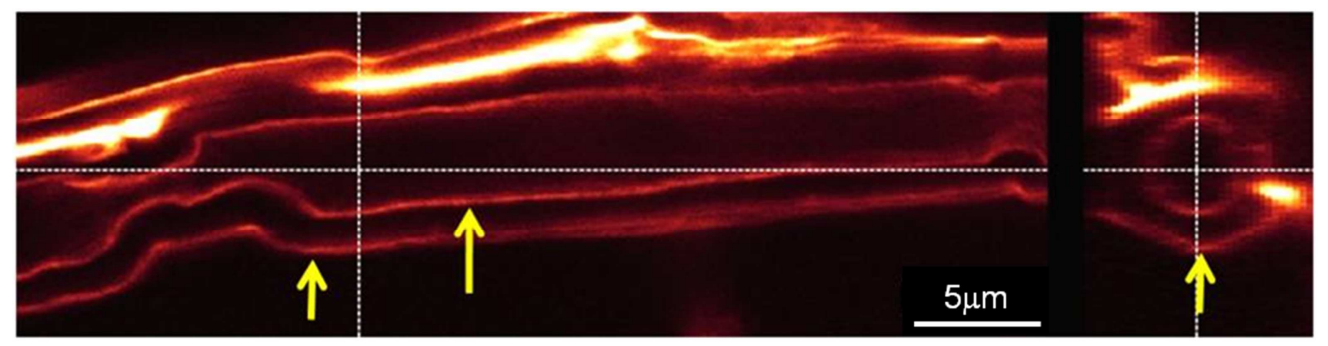

(b)

Figura 37 - Imagens de fluorescência de fibras de eucalipto: (a) pré-tratada com xilanase (FETE), mostrando a fluorescência do PTHT-PPV na superfície da fibra; (b) não pré-tratada com ácido e/ou xilanase (FENT), mostrando detalhes como parede interna e externa, bem como, um corte confocal evidenciando que a fibra é tubular e oca. Escala das imagens $=\mathbf{5} \boldsymbol{\mu m}$. 
As Figuras 38a e 38b mostram como a camada de PTHT-PPV está depositada sobre a superfície da fibra FENT e, pode evidenciar detalhes anteriormente só observados na microscopia eletrônica de alta resolução (MEV-FEG). Pode-se observar no corte confocal na Figura 38a que o polímero consegue mostrar esses detalhes da superfície da fibra com alta definição. A Figura 38b mostra superposição de planos confocais distintos medidos no modo de empilhamento z que reproduz os detalhes da fibra que se aproximam muito daqueles observados por MEV-FEG. Pelas setas, é possível se verificar também, detalhes como os orifícios notados antes nos experimentos com microscopia eletrônica (Figura 33b). Provavelmente, a difusão da solução de PTHT-PPV no interior da na fibra é facilitada pela presença desses orifícios.

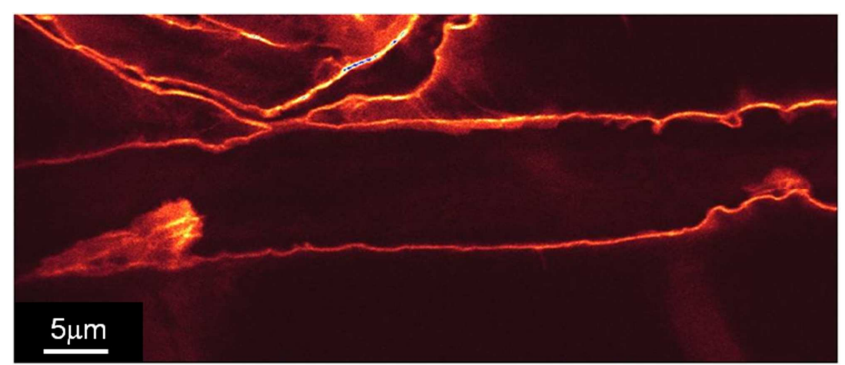

(a)

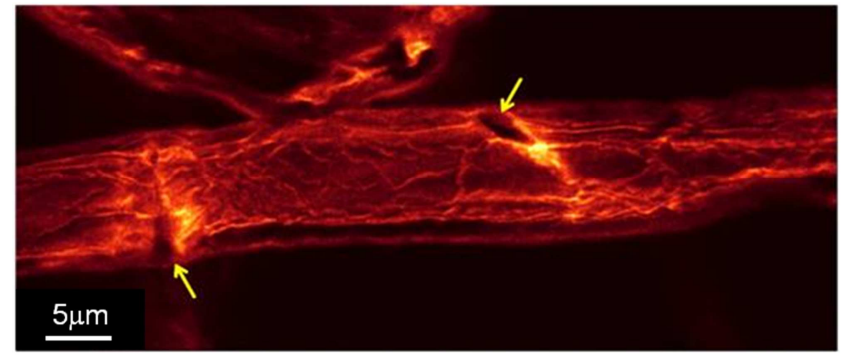

(b)

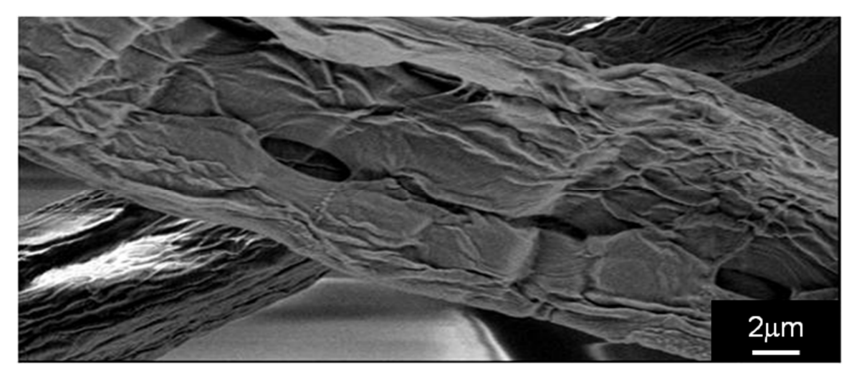

(c)

Figura 38 - Imagens de fluorescência de fibras de eucalipto pré-tratada com enzima (FETE) mostrando: (a) a fluorescência do PTHT-PPV na superfície da fibra; (b) detalhes como buracos na superfície da fibra. Escala das imagens $=5 \mu \mathrm{m}$. Detalhes da imagem de MEV-FEG da fibra é mostrado para comparação. 
A técnica CLSM é também espectroscópica e permite distinguir elementos com espectros de emissão em região espectral distinta. Um exemplo disso pode ser visto na Figura 39, onde são mostradas imagens da fluorescência medida em regiões espectrais envolvendo tanto da lignina como do PTHT-PPV, contidos em uma fibra de eucalipto pré-tratada com ácido e enzima (FETAE). Essas imagens foram obtidas simultaneamente no microscopio de fluorescência confocal por varreudra laser, em dois canais diferentes. Um canal medindo na faixa espectral de 540-650 $\mathrm{nm}$ para o PTHT-PPV e outro, fixado na faixa 410-440 $\mathrm{nm}$ para a lignina. Veja que cada canal representa apartir das imagens (Figura 39), a emissão de luz do PTHT-PPV, da lignina e a superposição das duas emissões (PTHT + lignina). Veja que, como observado anteriormente, o PTHT-PPV cobre a parte superfícial da fibra.

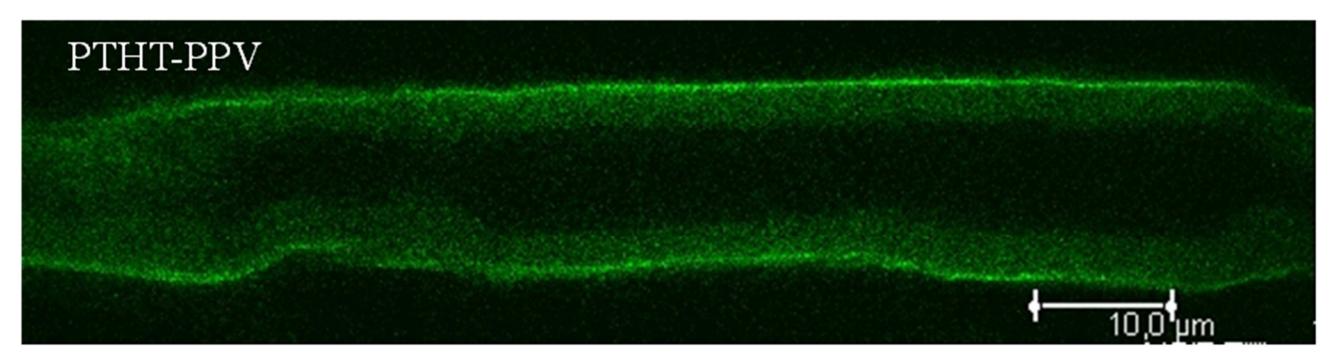

(a)

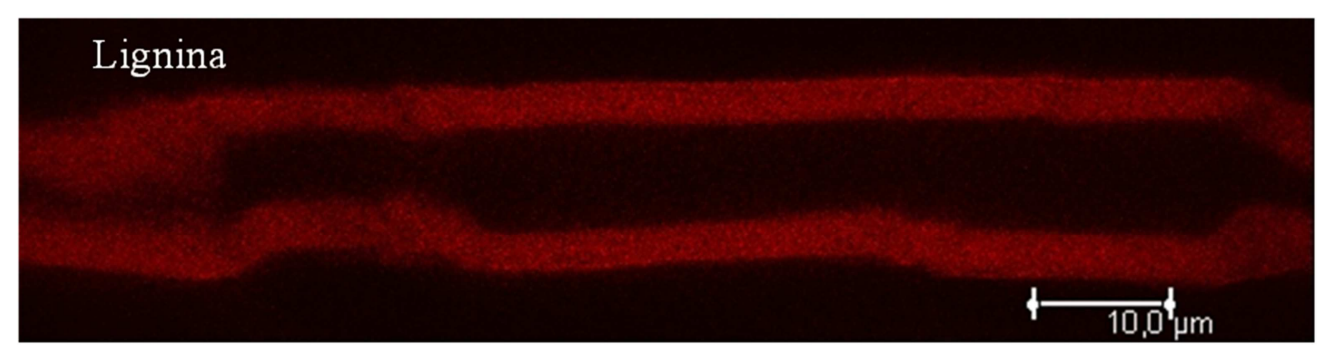

(b)

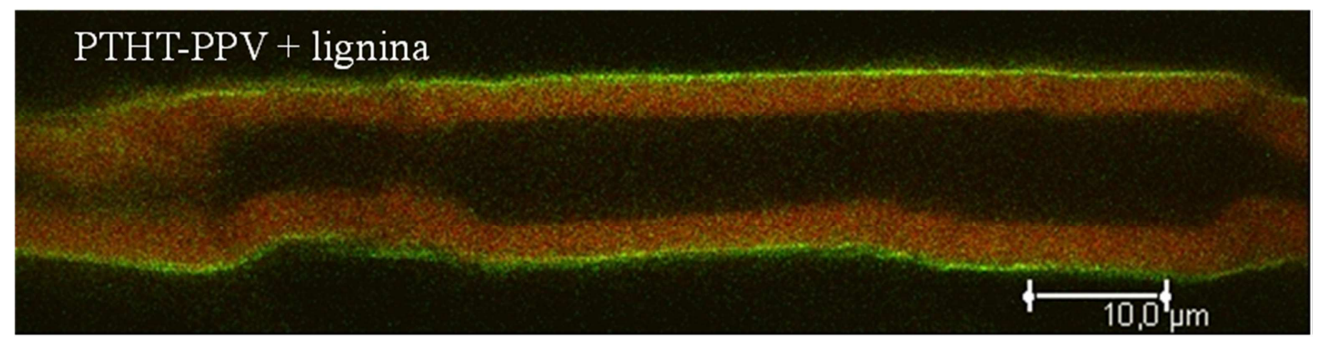

(c)

Figura 39 - Imagens obtidas a partir de diferentes canais no microcopio confocal de fluorescência mostrando a emissão (a) do PTHT-PPV; (b) da lignina e (c) do PTHT-PPV e da lignina juntos. Escala das imagens $=10 \mu \mathrm{m}$. 
A técnica CLSM permite obter dados qualitativos sobre as dimensões da parede celular e a uniformidade do material estudado. A comparação dos perfis de intensidade da fluorescência ao longo de uma linha transversal obtidos das imagens em altíssima resolução (à direita) para as fibras de eucalipto são mostrados na Figura 40. Estes perfis foram tirados de imagens usando o mesmo aumento de fibras contendo PTHT-PPV apenas na parede externa (acima), tanto na parede externa como interna (meio) e sem PTHT-PPV (abaixo, apenas emissão da lignina). Detalhe da estrutura de uma fibra contendo PTHT-PPV e a linha transversal de medida também é mostrado através de um corte confocal.

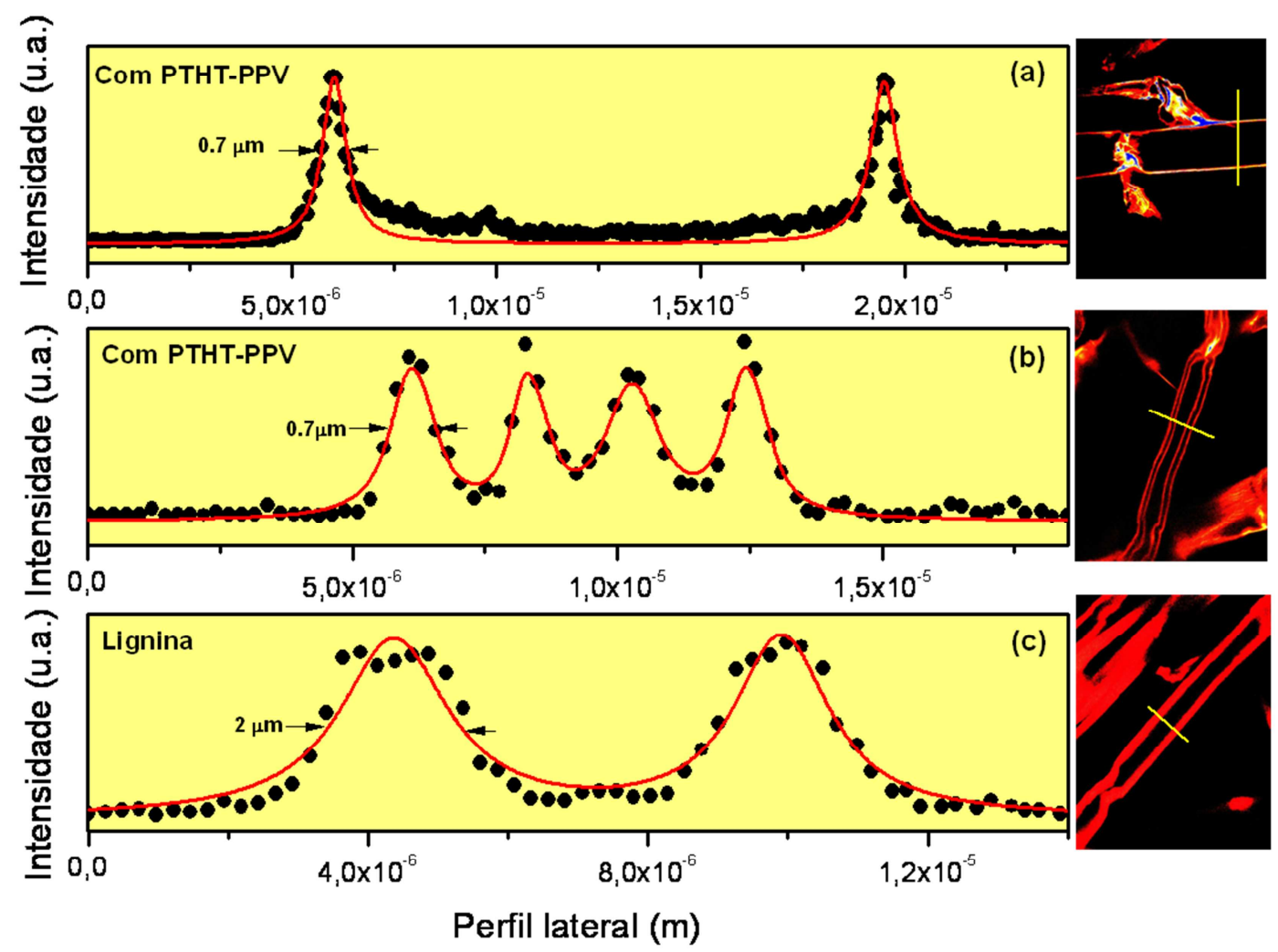

Figura 40 - Fibra de eucalipto: a) que não recebeu nenhum tipo de pré-tratamento (FENT), mas imersa em PTHT-PPV; b) que recebeu pré-tratamento com ácido em seguida com xilanase (FETAE), com o PTHT-PPV e c) que recebeu pré-tratamento com ácido em seguida com xilanase (FETAE) sem PTHT-PPV.

$\mathrm{Na}$ Figura 40, pode-se ver que os perfis de fluorescência através do corte transversal podem ser ajustados por curvas gaussianas (vermelho). A largura destas gaussianas permite pelo menos espessura da parede celular que é de $\sim 2 \mu \mathrm{m}$. Já a largura 
da camada PTHT-PPV na superfície deve ser muito menor do que a avaliada de $\sim 0,7 \mu \mathrm{m}$, já que a resolução lateral permitida pela óptica é de $\sim 0,3 \mu \mathrm{m}$. As mesmas intensidades dos perfis de luminescência indicam que o PTHT-PPV é incorporado uniformemente nas paredes externas e internas das fibras.

Estes perfis de intensidade nos permitiram quantificar a espessura da parede da fibra com maior precisão e mensurar efeitos de pré-tratamentos com detalhes. A espessura de algumas das fibras é mostrada na Tabela 5. Veja que em relação à fibra não pré-tratada, as FETA e FETAE, FETE e FETEA apresentaram menores espessuras, sendo menor ainda nas fibras pré-tratadas inicialmente com ácido: FETA e FETAE. Isso provavelmente é decorrente do pré-tratamento ácido, que deve ter agido de forma agressiva na parede das fibras, resultando em menores espessuras de parede. Estes perfis de intensidade nos permitiram quantificar a espessura da parede da fibra com maior precisão, possibilitando assim que com um tratamento estatístico o parâmetro espessura seja utilizado para mensurar efeitos de diferentes pré-tratamentos sobre a espessura da fibra. No presente trabalho, este tratamento estatístico não foi realizado, devido ao limitado acesso ao equipamento.

Tabela 5 - Espessura da parede de algumas fibras de eucalipto na presença de PTHT-PPV.

\begin{tabular}{lc}
\hline Amostras & Espessura $(\boldsymbol{\mu m})$ \\
\hline FENT & 2,5 \\
FETA & 2,1 \\
FETAE & 1,9 \\
FETE & 2,4 \\
FETEA & 2,3 \\
\hline
\end{tabular}

A possibilidade de obter imagens 3D é um diferencial da técnica CLSM em relação às outras técnicas de microscopia (de fluorescência) convencionais. Com esse tipo de imagens, é possivel mapear como as fibras se organizam tridimensionalmente. É interessante estudar como esta imagem é modificada com a incorporação do PTHT-PPV. Estas imagens podem ser giradas em até 75 graus com um software adequado, o que não pode ser apresentado no trabalho impresso. No entanto, as imagens 3D das fibras de eucalipto sem e com PTHT-PPV, para um dado ângulo de visão, são apresentadas nas Figuras 41a e 41b, respectivamente. 
A imagem da Figura 41a tem sua origem na fluorescência provinda da lignina na parede da fibra de eucalipto, a FENT. Nessa amostra, em especial, a geometria tubular apresentada anteriormente, não está presente. Pode-se notar que, estas fibras apresentamse, em sua maioria, colapsadas em forma de fita, o que pode ser efeito da preparação das mesmas. Mas o importante nesse caso foi verificar o efeito do PTHT-PPV nas imagens. A incorporação do PTHT-PPV sobre a superfície e o contraste obtido pela baixa absorção e emissão da lignina permite, obter imagens com baixo sinal/ruído e com muitos detalhes (Figura 41b). É interessante notar que a incorporação do PTHT-PPV nas paredes interiores permite a reprodução de uma imagem do tipo "Raio-X" das fibras e, com isso, obter informações adicionais não encontradas nas imagens somente da superfície das fibras (Figura 41a).

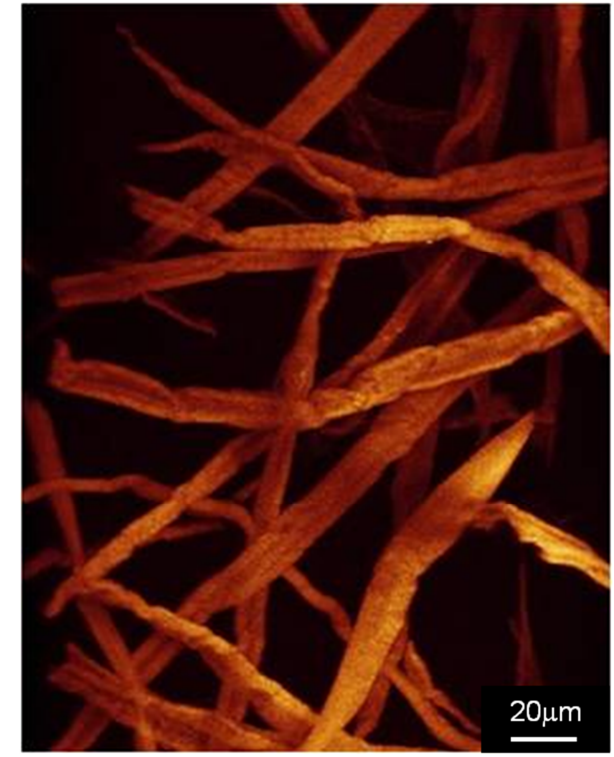

(a)

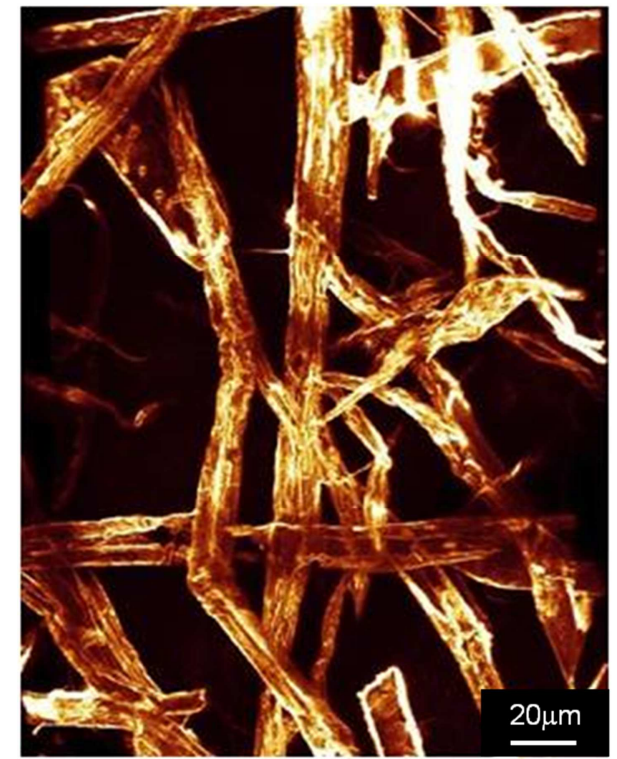

(b)

Figura 41 - Imagens de microscopia confocal de fluorescência em 3D de fibras de eucalipto (FENT) sem (a) e com (b) o PTHT-PPV. Escala das imagens $=20 \mu \mathrm{m}$.

\subsubsection{Difusão e incorporação do polímero luminescente sobre fibras de eucalipto}

As Imagens de microscopia confocal nos modos de fluorescência e transmissão foram feitas simultaneamente, visando acompanhar em escala de tempo o processo de 
difusão e incorporação do polímero luminescente nas fibras. Essas imagens são mostradas nas Figuras 42 e 43. Nesse experimento, uma gota de solução aquosa contendo PTHTPPV foi colocada sobre fibras previamente depositadas na superfície de uma lâmina de vidro. Esta solução se difundiu lentamente e facilmente pelas fibras devidas, à porosidade das mesmas. O microscópio confocal foi ajustado para fazer as imagens de 10 em 10 segundos, a partir do momento que a solução entrasse no seu campo de visão. Como a fibra com o PTHT-PPV emite muito mais do que a fibra sem este polímero, o microscópio foi ajustado em sensibilidade baixa de detecção de modo a não saturar as imagens após a sua incorporação.

A Figura 42a (43a) é imagem de fluorescência (transmissão) ajustada nessa condição antes da medida. Ela está relacionada ao estágio inicial, isto é, a região sem a solução de PTHT-PPV. Logo, se vê nesta imagem apenas a fluorescência da lignina nas fibras, sendo a intensidade bastante baixa. Os círculos coloridos são difrentes pontos sobre a fibra em que foi medida a intensidade da fluorescencia ou da luz transmitida para cada quadro. O tempo total de medida foi de aproximadamente 500 segundos, ou seja, foram feitos a aquisição de 50 quadros. Este tempo foi suficiente para medir a difusão da solução pelas fibras e o processo de secagem das mesmas. Estes regimes de difusão e secagem podem ser melhor acompanhados nas Figuras 43.

A Figura 42b (43b) é a imagem que mostra a penetração da solução por entre as fibras no modo de fluorescência (transmissão). Este quadro está relacionado ao instante entre o intervalo de 40-210 segundos depois que a solução de PTHT-PPV atingiu a região de estudo. Nesta etapa do processo de difusão, a solução de PTHT-PPV não apresentou muito brilho. Após cerca de 400 segundos (Figuras 42c e 43c), observa-se na mesma região em estudo, que o brilho das fibras aumentou e que a solução de PTHT-PPV parece ter se espalhado uniformemente sobre a camada de fibra. Como nenhuma solução foi observada entre as fibras, acreditamos que a solução foi absorvida pelas fibras - fato que pode ser verificado na imagem de transmissão 43c. Este quadro corresponde à etapa após a secagem ou adsorção da solução pelas fibras. 


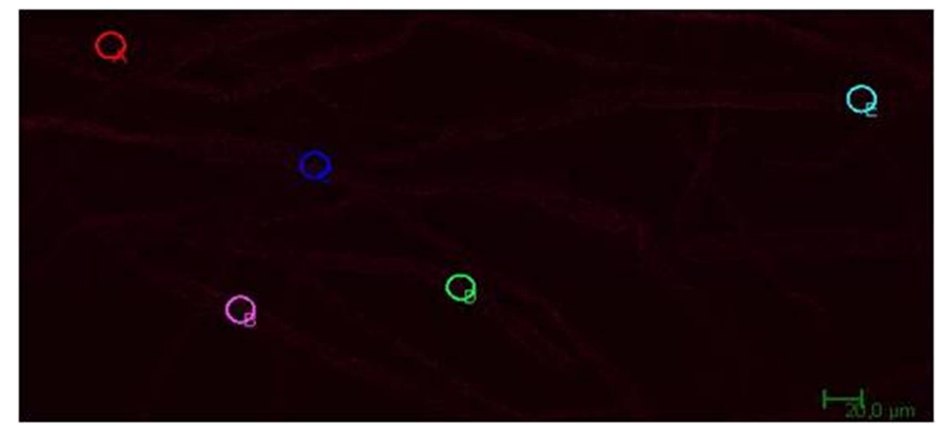

(a)

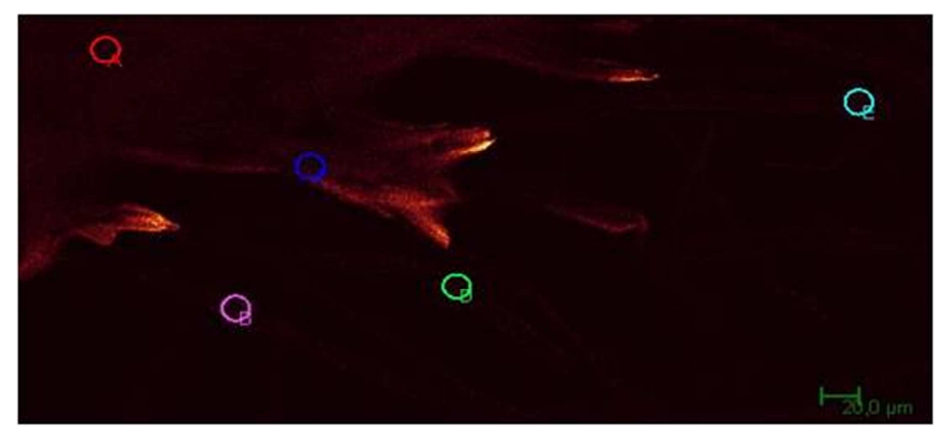

(b)

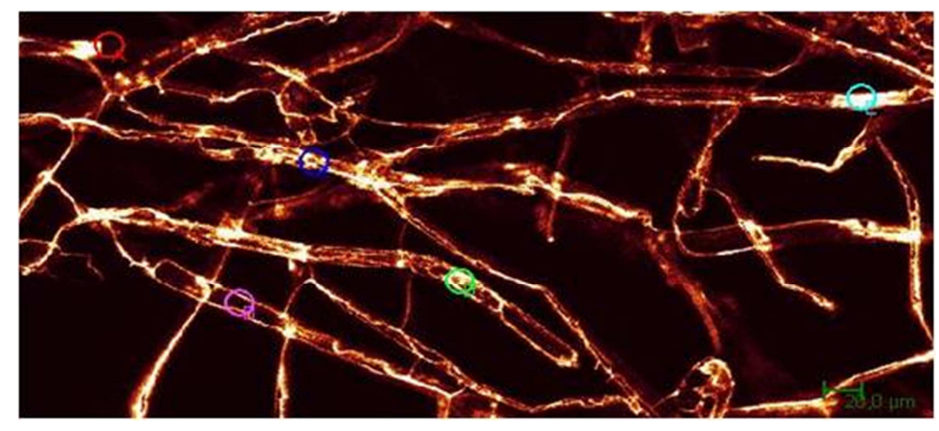

(c)

Figura 42 - Imagens de microscopia confocal de varredura a laser (modo fluorescência) do filme de fibra de eucalipto não pré-tratada com ácido e/ou xilanase (FENT): a) no tempo de 0 segundo; b) entre os tempos de 40-210 segundos e c) após 400 segundos da aplicação do PTHT-PPV. As demarcações representadas por círculos coloridos são regiões fibrilares analisadas na Figura 42. Escala das imagens $=20 \mu \mathrm{m}$. 


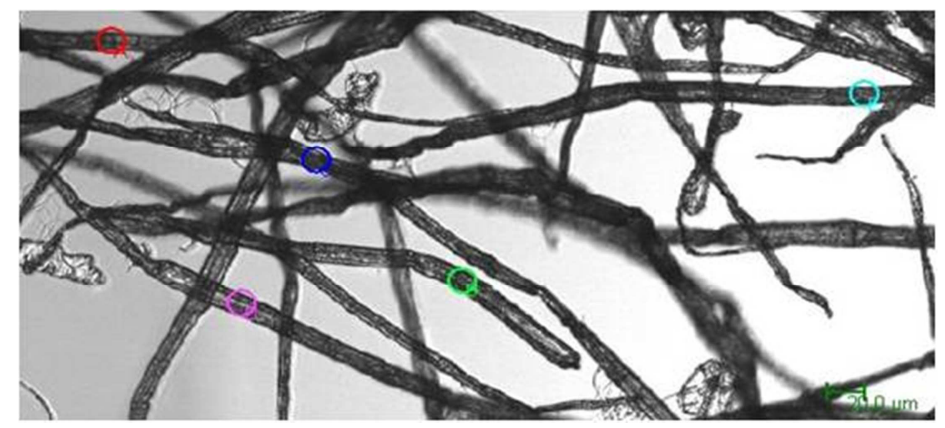

(e)

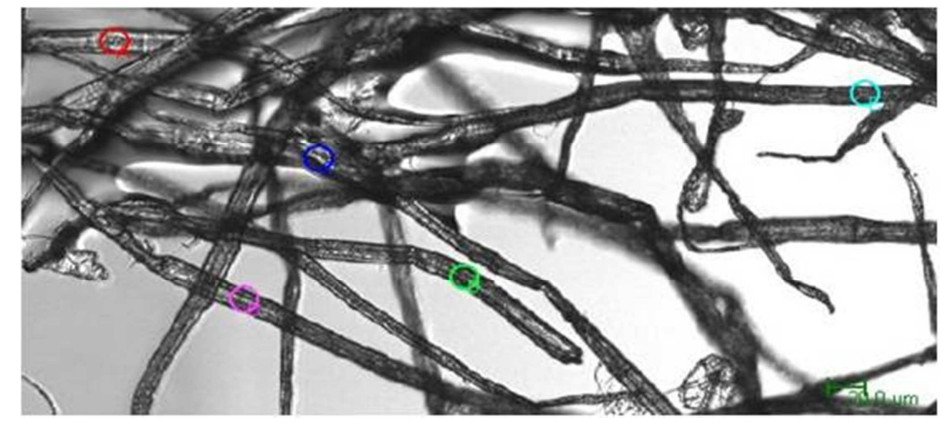

(d)

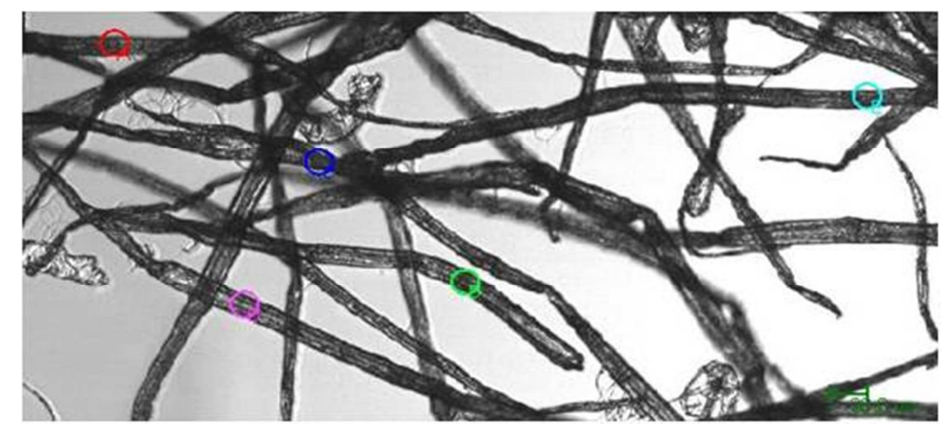

(c)

Figura 43 - Imagens de microscopia confocal de varredura a Laser (modo transmissão) do filme de fibra de eucalipto não pré-tratada com ácido e/ou xilanase (FENT): a) no tempo de 0 segundo; b) entre os tempos de 40-210 segundos e c) após 400 segundos da aplicação do PTHT-PPV. As demarcações representadas por círculos coloridos são regiões fibrilares analisadas na Figura 42. Escala das imagens $=20 \mu \mathrm{m}$.

A evolução temporal da intensidade luminosa da fluorescência e da luz transmitida das áreas selecionadas nas Figuras 42 e 43 podem ser acompanhadas nas Figuras 44a e 44b, respectivamente. Observando o gráfico das Figuras 44a e 44b, é possível associar três etapas distintas separadas pelas setas. A primeira etapa entre 0-40 segundo corresponde à região temporal em que a solução d PTHT-PPV ainda não tinha alcançado as áreas circulares. Na segunda etapa entre 40 s e 210 s a solução difundiu rapidamente por entre as fibras. Nesse caso, ocorreu um grande aumento da intensidade da luz transmitida ocasionado pelo maior acoplamento com a objetiva, devido à presença 
da solução por toda a área de observação. Porém, a luminescência apresentou um pequeno aumento nessa fase. Após esta etapa, a intensidade da luz transmitida voltou rapidamente aos patamares iniciais, ou que indicou a secagem das fibras ou absorção da solução por elas. Na terceira etapa, a intensidade da luminescência aumentou até atingir a saturação em todos os pontos de observação. Comparando os dois gráficos na Figura 44, foi possível correlacionar o aumento da luminosidade (Figura 42) e redução (43), que ocorreu em torno de 210 segundos, com a absorção e concentração de moléculas de PTHT-PPV nas paredes das fibras de eucalipto. A imagem 42c mostra que as fibras foram cobertas pelo polímero luminescente.

(a)

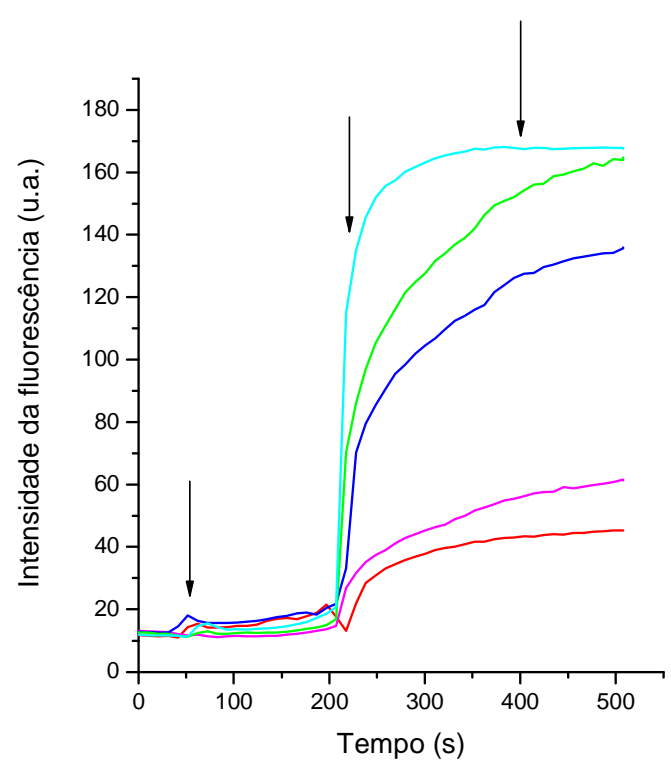

(b)

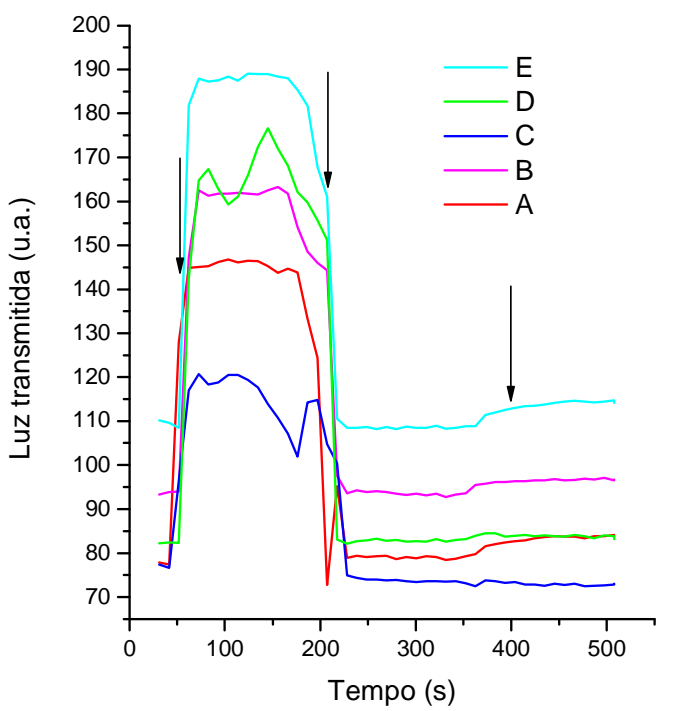

Figura 44 - Gráfico da evolução temporal: (a) da intensidade luminosa das áreas delimitadas na Figura 40, em função do tempo de difusão da solução de PTHT-PPV na fibra e (b) de intensidade da luz transmitida, nas áreas delimitadas na Figura 41, em função do tempo de difusão da solução de PTHT-PPV na fibra. As setas indicam intensidade de luz laminosa e transmitida nos tempos de 40, 210 e 400 segundos da aplicação do PTHTPPV. 


\subsection{Interação e adsorção das fibras de eucalipto com o polímero luminescente}

No tópico anterior, foi observado que o PTHT-PPV incorporou nas fibras de eucalipto que, possibilitou a visualização das mesmas por meio de técnicas de microscopia de fluorescência. Com o intuito de entender e quantificar a capacidade adsorssiva de fibras de eucalipto em função dos pré-tratamentos foi realizado experimentos de arraste descritos na seção 3.2.12. Nos experimentos, variou-se a concentração de fibras em uma solução contendo PTHT-PPV em concentração tal que a sua intensidade de absorbância entre 300 e $400 \mathrm{~nm}$ fosse da ordem de 0,1, ou seja, fixouse a concentração de PTHT-PPV (50 $\mu \mathrm{L}$ em $10 \mathrm{ml}$ de água) e, variou-se a proporção de massa de fibra na solução. Dessa maneira, foram garantidas as condições de concentração de PTHT-PPV, suficientes para se observar o processo de arraste pelas fibras ao se medir a absorção e fluorescência das soluções sobrenadantes após a centrifugação. Vale ressaltar que, a centrifugação foi feita também para retirar possíveis resíduos de fibras na solução estudada, eliminando processos de espalhamento nas medidas ópticas.

O experimento de arraste foi realizado para todas as amostras de fibras de eucalipto investigadas neste trabalho, ou seja, para a FENT, FETA, FETAE, FETE e FETEA. Os espectros de absorbância e fluorescência das soluções sobrenadantes contendo PTHT-PPV em função da massa da fibra FETE incorporada à solução antes do processo de centrifugação podem ser observados na Figura 45. A banda de absorção típica do segmento conjugado do PTHT-PPV observada na região espectral entre 280-340 nm (Figura 45a), enquanto que a emissão máxima em 420 nm (Figura 45b). Observa-se que tanto a absorbância como a fluorescência, após a centrifugação, decaiu conforme foi aumenta a concentração de fibras na solução - provavelmente devido à adsorção das moléculas de PTHT-PPV pelas fibras de eucalipto. O mesmo tipo de comportamento pode ser visto, por meio da variação do máximo da intensidade da fluorescência em função da massa de todas as fibras de eucalipto com diferentes pré-tratamentos na Figura 46a. A proporção mássica necessária para se atingir o ponto de máxima adsorção (o ponto onde a intensidade da fluorescência da solução do sobrenadante cai ao valor praticamente zero) para cada uma das fibras, é mostrado na Figura 46b. 

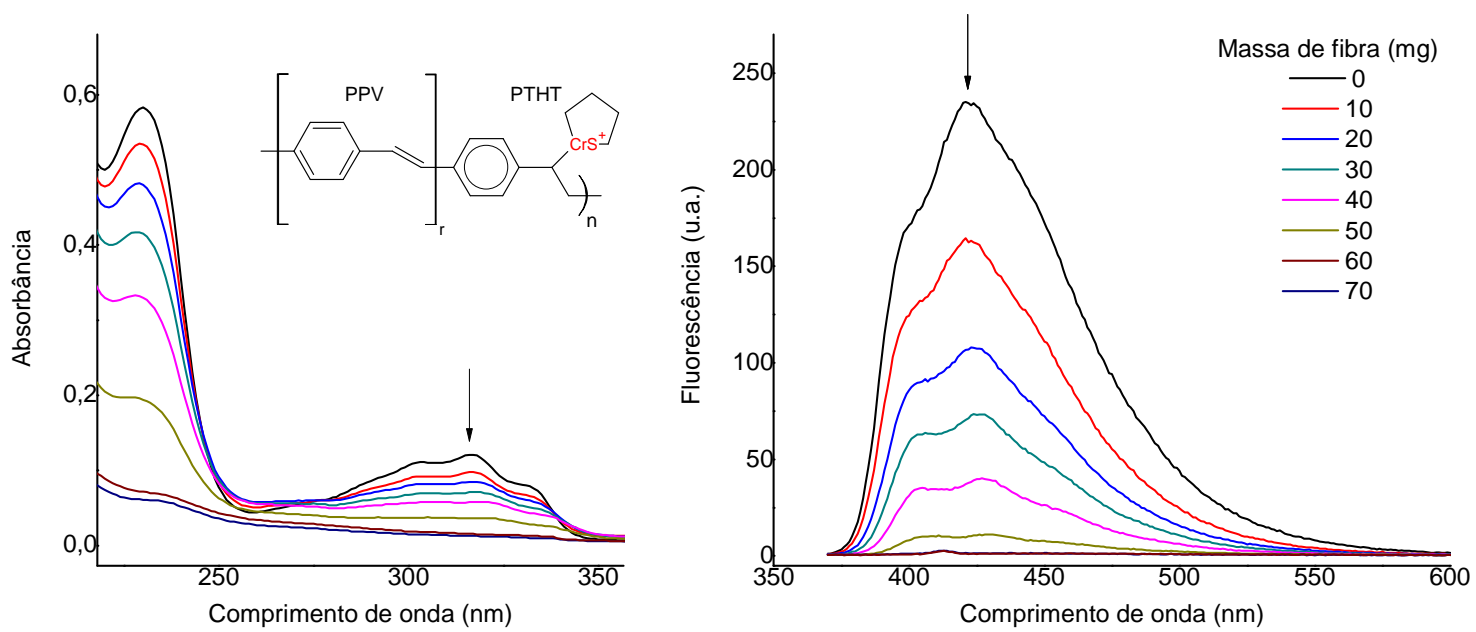

Figura 45 - Medidas da solução sobrenadante contendo resíduos de PTHT-PPV que não foi adsorvido pelas paredes das fibras lignocelulósicas de eucalipto: (a) absorção e (b) fluorescência em função da massa de fibras.

(a)

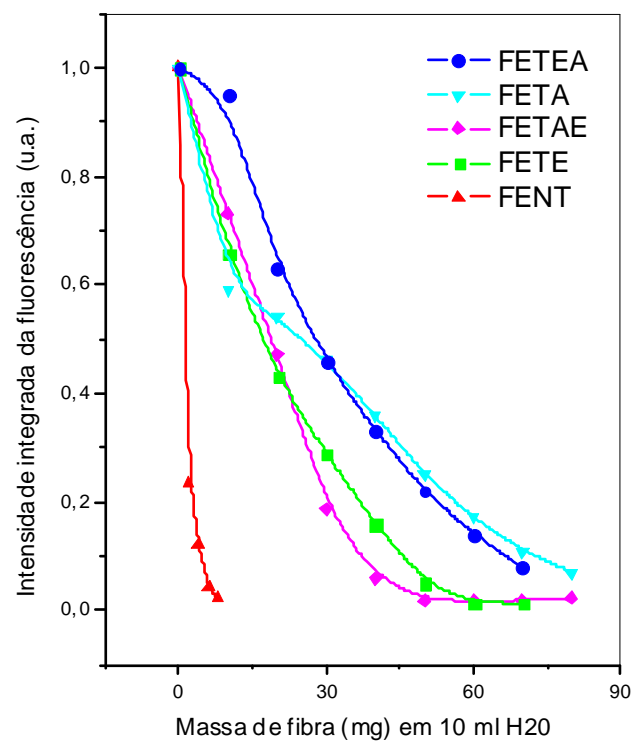

(b)

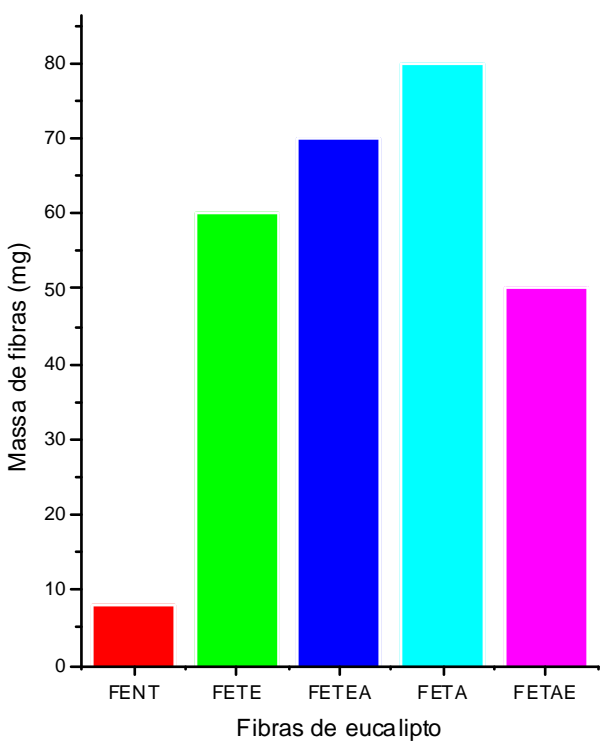

Figura 46 - Medidas: (a) Intensidade integrada da fluorescência; (b) Proporção de massa de fibras de eucalipto relativo ao ponto de máxima adsorção.

Na Figura 46, se observou que a adsorção de PTHT-PPV foi mais eficiente para FENT, pois com pouco menos de $10 \mathrm{mg}$ (cerca de $8 \mathrm{mg}$ ) de fibra, já se atingiu o ponto de máxima adsorção para a concentração de PTHT-PPV utilizada. Nesta fibra é que foi 
medida a incorporação do PTHT-PPV nas suas paredes internas. Já as fibras de eucalipto, as quais sofreram pré-tratamentos com ácido e/ou xilanase, verificou-se que para a fluorescência do PTHT-PPV atingir o ponto de máxima adsorção, foi necessário uma quantidade entre 5 a 6 vezes maior dessas fibras.

Essa diferença no comportamento da adsorção das fibras pelo PTHT-PPV pode ser devido a vários fatores. Primeiramente, o fato do PTHT-PPV ser incorporado pelas paredes internas da fibra FENT aumentou a sua adsorção de no máximo duas vezes (área aumenta praticamente duas vezes). No entanto, a penetração da solução nos orifícios dessas fibras e a posterior difusão em seu interior são efeitos que parecem ser fundamentais para a análise e, para a aplicação dos métodos utilizados nesse trabalho para a caracterização dos pré-tratamentos envolvidos na degradação da biomassa em geral. Estes aspectos indicaram que a fibra não pré-tratada FENT, foi mais suscetível à interação com PTHT-PPV e que as suas propriedades superficiais (radicais interagentes, cargas, caráter hidrofóbico ou hidrofílico, etc.), favoreceram a penetração e difusão da solução em seu interior. Essa suscetibilidade de interação maior com um polieletrólito positivo como o PTHT-PPV favoreceu uma maior interação e incorporação por massa de fibra nos experimentos apresentados na Figura 46.

\subsection{Microscopia de imagem de tempo de vida de fluorescência}

A microscopia de imagem de tempos de vida de fluorescência (FLIM) vem sendo usado como uma ferramenta poderosa para estudos espacialmente resolvidos de síntese da parede celular, degradação da lignina, polpação e para a localização de marcadores fuorescentes empregados para imunomarcação de madeira ou de fibras de madeira (HAFRÉN et al., 2009). Neste trabalho, o FLIM foi empregado para investigar a incorporação do PTHT-PPV em fibras de eucalipto.

Na Figura 47a, imagem de um corte confocal de uma fibra contendo PTHT-PPV incorporado é mostrada. A fibra foi excitada em $405 \mathrm{~nm}$ por um laser CW de diodo. Nessa imagem, observa-se que o PTHT-PPV cobriu as paredes interna e externa da fibra. A mesma imagem é mostrada na Figura 48b, contudo, produzida com a técnica FLIM 
excitando a amostra no comprimento de onda de $405 \mathrm{~nm}$ por um laser de diodo pulsado em $80 \mathrm{MHz}$. Nesse caso, cada pixel da imagem é associado com um tempo de decaimento característico de cada especie representado pelo conceito cor. As cores variando do azul ao marrom correspondem a tempos de decaimento variando entre 1 e 3 ns. Pode-se ver que as superfícies das paredes internas e externas apresentaram tempos de vida menores, representados por verde. E o interior, entre as paredes da fibra tempo de vida maior, representado por marrom. Esta distinção permite relacionar à presença do PTHT-PPV nas superfícies interna e externa, e à lignina no interior da parede. Além disso, a imagem FLIM permitiu visualizar pontos associados a um orifício sem lignina e regiões da parede da fibra que sofreu maior ação do pré-tratamento - ou seja, regiões onde a concentração da lignina se apresentou menor (circulo pontilhado em cor rosa na Figura 47b).
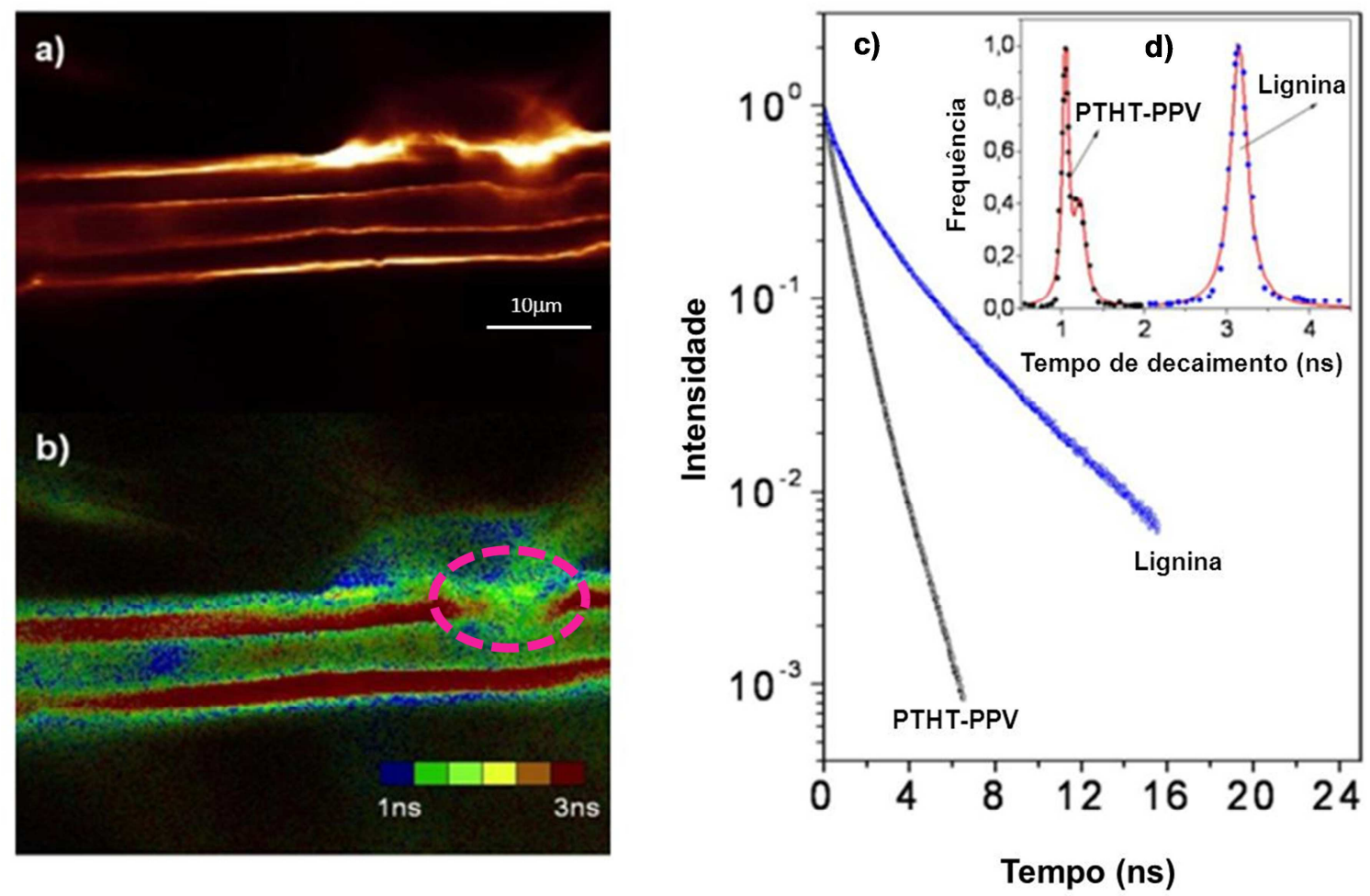

Figura 47 - a) Imagem de microscopia confocal mostrando a contribuição da fluorescência do PTHTPPV na superfície interna e externa das paredes da fibra; b) Imagem FLIM da mesma fibra mostrando os tempos de decaimento de fluorescência de cada espécie (lignina e PTHT-PPV) representados pelo conceito cor; c) curva de decaimento da fluorescência para o PTHT-PPV e da lignina contida na fibra em função do tempo da medida; d) distribuições dos tempos de decaimento da lignina e do PTHT-PPV obtidas da resposta da frequência (quantas vezes o sinal foi observado). Escala das imagens $=10 \mu \mathrm{m}$. 
As distribuições dos tempos de decaimento da lignina e do PTHT-PPV obtidas da resposta da frequência (quantas vezes o sinal foi observado) (Figura 47d), bem como as curvas de decaimento da fluorescência para o PTHT-PPV e da lignina contida na fibra em função do tempo da medida podem ser acompanhadas (Figura 47c). Vejam que a incorporação do PTHT-PPV na fibra foi claramente visualizada na imagem FLIM, resultando em um tempo de decaimento de fluorescência mais curto que para a lignina. Esse tempo de decaimento da fluorescência da lignina está relacionado aos inúmeros cromóforos contidos nela. Grupos cromóforos, tais como 7-dimetoxiflavona, 8-hidroxi3,7-dimethoxidibenzofuran-1,4-quinona e Desidrodivanilina, podem contribuir para as emissões em torno de $500 \mathrm{~nm}$ de comprimento de onda e acima (Figura 39); Coniferil álcool, Coniferaldeído, Cinamil alcool, Bifenil, Fenilcumarina, Dibenzodioxinas e Estilbenos contribuem para a faixa de emissão entre 300-450 nm de comprimentos de onda (Figura 39) (HAFRÉN et al., 2009; CASTELLAN et al, 1994; TYLLI et al, 1995, GARDRAT et al, 2004; MACHADO et al, 2006; ALBINSSON et al, 1999)<smiles>Cc1ccc2c(=O)cc(-c3ccccc3)oc2c1</smiles>

(a)<smiles>COC1=CC(=O)C2=C(OC3CC(OC)C(O)CC23)C1=O</smiles><smiles>COc1cc(C=O)cc(-c2cc(C=O)cc(OC)c2O)c1O</smiles>

(c)

(b)

Figura 48 - Cromóforos de lignina os quais contribuiem para as emissões em torno de 500 nm e comprimentos de onda acima: (a) 7-dimetoxiflavona, (b) 8-hidroxi-3,7-dimethoxidibenzofuran-1,4-quinona e (c) Desidrodivanilina 
<smiles>COc1cc(C#CC=O)ccc1O</smiles>

(a)

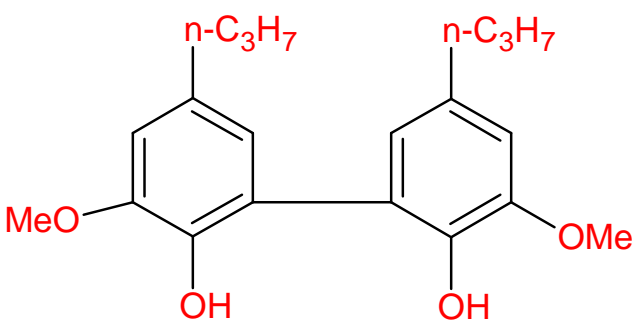

(d)<smiles>CCCc1cc(OC)c2c(c1)-c1cc(CCC)cc(OC)c1OC(c1ccc(OCC)c(OC)c1)CO2</smiles><smiles>COc1cc(C=CC=O)cc(C)c1OC</smiles>

(c)

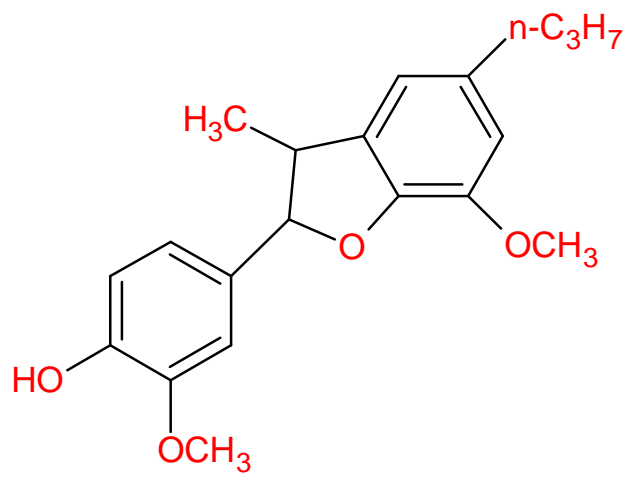

(e)<smiles>CCCc1cc(C=Cc2cc(C)c(OC)c(OC)c2)c(O)c(OC)c1</smiles>

(g)

Figura 49 - Cromóforos de lignina os quais contribuiem para a faixa de emissão entre 300-450 $\mathrm{nm}$ de comprimentos de onda: (a) Coniferil álcool, (b) Coniferaldeido, (f) Cinamil alcool, (c) Bifenil (b) Fenilcumarina, (e) Dibenzodioxinae e (d) Estilbeno. 


\section{Conclusões}

Metodologias ópticas avançadas de altíssima sensibilidade e resolução espacial/temporal que vão muito além do limite de difração foram desenvolvidas nas últimas décadas. É de grande importância e interesse desenvolver e aplicar estas novas metodologias ópticas com resolução microscópica à cadeia de bioconversão da biomassa da cana de açúcar e bioetanol. Mais especificamente, estas metodologias ópticas, neste trabalho, permitiriam a caracterização de um maior número de etapas no processo envolvido na bioconversão. Aqui, a caracterização das modificações estruturais foi determinante para o entendimento da ação ácida e enzimática e poderá servir de feedback para o controle de processos na cadeia de bioconversão da biomassa em etanol de segunda geração.

Nesse trabalho, foi demonstrado que microscopia confocal de fluorescência se mostrou apropriada para a caracterização estrutural de um sistema heterogêneo como fibras de lignocelulósica de eucalipto. A lignina que compõe esse material apresentou propriedades luminescentes quando excitada no ultravioleta, e baixas intensidades de absorção quando excitadas por comprimentos de ondas apropriados para a microscopia confocal, o que desfavoreceu um estudo mais detalhado da estrutura do substrato fibroso. Considerando este problema, no presente trabalho, foi desenvolvida uma nova metodologia que permitiu a incorporação de um polímero luminescente às fibras, ampliando a faixa de utilização das técnicas de luminescência para a determinação da estrutura das fibras após os vários pré-tratamentos. O polímero utilizado foi o poli(cloreto de tetraidrotiofeno de xililideno) (PTHT) que se apresentava parcialmente convertido em Poli-(fenileno vinileno) (PPV), logo, chamado neste trabalho de PTHT-PPV. Este polímero foi depositado sobre os filmes de fibras lignocelulosicas de eucalipto. A difusão capilar da solução aquosa polimérica no meio fibroso permitiu a incorporação instantânea nas paredes externas e internas das fibras que não sofreu pré-tratamento ácido e/ou xilanase (FENT), enquanto que o contrário foi verificado para as fibras pré-tratadas com ácido e/ou xilanase. Portanto, os pré-tratamentos com ácido e/ou xilanase dificultaram a difusão do PTHT-PPV no interior oco das fibras.

Das análises dos resultados de espectroscopia de fluorescência obtidos neste trabalho, pode-se sumarizar que conforme os pré-tratamentos a intensidade da 
fluorescência nas fibras de eucalipto aumentou consideravelmente. As maiores intensidades de fluorescência foram apresentadas pelas fibras pré-tratadas inicialmente com ácido (FETAE e FETA), indicando que a fluorescência em fibras lignocelulósicas pode não estar relacionada somente com o teor de lignina, mas também, há retirada de grupos moleculares que é capaz de comprometer a fluorescência das fibras em uma dada região espectral. Para a solução de lignina em diferentes pH, houve uma redução na intensidade da fluorescência e da absorbância com a redução do pH e o efeito contrário, com o aumento do pH, o que indicou ser devido à agregação e desagregação dos monômeros de lignina que emitem nesta região.

Dos resultados de espectroscopia de ressonância magnética nuclear com polarização cruzada (CP/MAS - TOSS RMN), as fibras de eucalipto pré-tratadas e o bagaço de cana-de-açúcar apresentaram sinais relacionados à celulose, hemicelulose e lignina. Da comparação entre os espectros das fibras de eucalipto pré-tratadas, apesar de a técnica ser extremamente eficiente, não foi possível observar alterações significativas com os pré-tratamentos, que deve estar relacionado à quantidade de lignina e hemicelulose nessas fibras estarem abaixo do limite de detecção da técnica (5\%) devido aos pré-tratamentos.

Quanto aos resultados de espectroscopia no infravermelho (FT-IR), tanto os espectros das fibras de eucalipto quanto ao de bagaço de cana de açúcar apresentaram sinais relacionados à celulose, hemicelulose e a lignina. Da compação dos espectros, os relacionados ao pré-tratamento enzimático e combinados (ácido-xilanase ou xilanaseácido) foram os que apresentaram maior efeito na redução de grupos funcionais ligados a lignina e a hemicelulose, indicando que processos de pré-tratamentos combinados podem ser mais hábeis no processo de deslignificação de biomassa lignocelulósica do que os prétratamentos isolados (somente com ácido ou xilanase).

As imagens de microscopia (transmissão) mostraram que as fibras de eucalipto eram transparentes e formadas por regiões mais estreitas (chamadas neste trabalho de estrangulamentos ou empescoçamento), confirmados pelas imagens de microscopia eletrônica. Além disso, as imagens de microscopia (eletrônica) mostraram também que as fibras eram formadas por uma superfície rugosa contendo orifícios. Esses orifícios apresentaram desgastados, sendo mais evidentes nas fibras que foram pré-tratadas somente com xilanase, o que indicou uma maior eficiência do pré-tratamento enzimático. Quanto às imagens CLSM, elas demonstraram que a lignina se concentrava nas paredes 
da fibra e as fibras apresentaram possuírem um formato tubular, ocas e mais estreitas nas regiões de estrangulamento. Além disso, as imagens CLSM demonstraram uma afinidade do PTHT-PPV com as fibras de eucalipto, o que possibilitou uma melhor visualização das mesmas. No que concerne à comparação dos pré-tratamentos das fibras de eucalipto, as imagens CLSM não apresentaram diferenças entre elas, provavelmente devido à baixa proporção de lignina nas fibras.

A afinidade do PTHT-PPV com as fibras de eucalipto foi confirmada pelos resultados dos experimentos de arraste. Os espectros de absorbância e de fluorescência apresentaram uma redução em função do aumento de fibras de eucalipto na solução. A fibra não pré-tratada com ácido e/ou xilanase foi a que apresentou maior afinidade com o PTHT-PPV uma vez que, para a fluorescência do PTHT-PPV atingir o ponto de máxima adsorção, os resultados indicaram a necessidade de uma maior proporção de massa para as fibras pré-tratadas com ácido e/ ou xilanase.

Quanto aos resultados de microscopia de imagem de tempos de vida de fluorescência (FLIM), os tempos de decaimento de fluorescência representados pelo conceito cor na imagem FLIM da fibra de eucalipto, indicou à presença do PTHT-PPV nas superfícies interna e externa da parede da fibra e à lignina no interior da parede. Sendo que PTHT-PPV apresentou tempo de decaimento de fluorescência mais curto do que a lignina. Além disso, a imagem FLIM permitiu observar regiões com baixa concentração de lignina causada pelo pré-tratamento da fibra.

Neste trabalho as técnicas empregadas na caracterização das fibras de eucalipto em função dos pré-tratamentos demonstraram ser complementares. A nova metodologia, baseada na incorporação de polímeros fluorescentes (marcadores) às fibras lignocelulósicas, apresentou ser adequada e promissora na caracterização de biomassa lignocelulósica pré-tratada. Novos estudos, relacionados à interação de polímeros fluorescentes (marcadores) com fibras lignocelulósicas pré-tratadas, são necessários para se obter uma melhor compreensão da ação e papel dos processos de pré-tratamento durante a bioconversão de biomassa lignocelulósica em etanol de segunda geração. 


\section{Referências}

AGARWAL, U. P. (2006). Raman imaging to investigate ultrastructure and composition of plant cell walls: distribution of lignin and cellulose in black spruce wood (Picea mariana). Planta, v.224, n.5, p.1141-1153.

AGUIAR, C. M. (2010). Hidrólise enzimática de resíduos lignocelulósicos utilizando celulases produzidas pelo fungo Aspergillus Níger. 106p. Dissertação (Mestrado) Centro de Engenharias e Ciências Exatas, Universidade Estadual do Oeste do Paraná, Toledo, 2010.

ALBINSSON, B.; LI, S.; LUNDQUIST, K.; STOMBERG, R. (1999). The origin of lignin fluorescence. Journal of Molecular Structure, v.508, n.14, p.19-27.

ALVIRA, P. et al (2010). Pretreatment technologies for an efficient bioethanol production process based on enzymatic hydrolysis: A review. Bioresource Technology, v. 101, n. 13, p. 4851-4861.

ARANTES, T. M. (2009). Uso de soluções hidrotrópicas na deslignificação do bagaço de cana-de-açúcar. 145p. Dissertação (Mestrado) - Instituto de Química de São Carlos, Universidade de São Paulo, São Carlos, 2009.

ATALLA, R. H.et al. (1980). 13C NMR spectra of cellulose polymorphs. Journal of the American Chemical Society, v.102, n. 9, p. 3251-3252.

ATKINS, P. W.; PAULA, J. (2004). Atkins: Físico-química. 7 ed. Rio de Janeiro: Livros técnicos e científicos (LTC). v. 2.

BALOGH, D. T.(1989). Efeito de solvente na obtenção de ligninas pelo processo organosolv. 110p. Dissertação (Mestrado) - Instituto de Física e Química de São Carlos, Universidade de São Paulo, São Carlos, 1989.

BARBOSA, L. C. A. et al. (2008). Determinação da relação siringila/guaiacila da lignina em madeiras de eucalipto por pirólise acoplada à cromatografia gasosa e espectrometria de massas (PI - CG/EM). Química Nova, v.31, n.8, p.2035-2041.

BENNETT A. E. et al. (1995). Heteronuclear decoupling in rotating solids. Journal of Chemical Physics, v.103, n.16, p.6951-6958.

BORGES, C. H. M. (2005). Propriedades ópticas das interfaces em filmes autoorganizados de poli(p-fenileno vinileno) ultrafinos: um estudo da dinâmica e da relaxação energética de portadores de cargas semicondutores orgânicos a base de polímeros emissores de luz. 2005. Tese (Doutorado em Física) - Instituto de Física de São Carlos, Universidade de São Paulo.

BODDEKE, F. R. et al. (1996). Fluorescence lifetime determination for application in microscopy. 13th International Conference on Pattern Recognition (ICPR'96). v.3, p.854, Austria, 1996. 
BOTARO, V. R. (1996). Deslignificação organossolve de bagaço de cana-de-açúcar: fracionamento e benzilação das ligninas obtidas. Tese (Doutorado) - Instituto de Química de São Carlos, Universidade de São Paulo, São Carlos, 1996.

BUCKERIDGE, M. S.; SANTOS, W. D.; SOUZA, A. P. As rotas para o etanol celulósico no Brasil. Disponível em: <http://mundodacana.posterous.com/2010/08/asrotas-para-o-etanol-celulosico-no.html>. Acesso em: 26 set. 2010.

CAO, Y.; TAN, H. (2006). Preparation and Properties of Microporous Cellulose Membranes from Novel Cellulose/Aqueous Sodium Hydroxide Solutions. Journal of Applied Polymer Science, v. 102, n.1, p.920-926.

CAMBUIM, K. B. Carvão de endocarpo de coco da baía ativado quimicamente com $\mathrm{H}_{3} \mathrm{PO}_{4}$ e fisicamente com vapor d'água produção caracterização, modificações químicas e aplicação na adsorção de íon cloreto. 137p. Tese (Doutorado) - Centro de Ciências Exatas e da Natureza, Universidade Federal da Paraíba, João Pessoa, 2009.

CANILHA, L. et al. (2010). Sacarificação da Biomassa Lignocelulósica através de pré hidrólise ácida seguida por hidrólise enzimática: uma estratégia de "desconstrução" da fibra vegetal. Revista Analytica, n.44.

CASTELLAN, C.; et al. (1994). Comparative study of Stone-ground Wood pulp and native Wood 2. Comparison of the fluorescence of stone-ground wood pulp and native wood. Journal of Photochemistry and Photobiology A: Chemistry, v.81, n.2, p.117122

CASTELLAN, A.; DAVIDSON, R.S. (1994). Steady-state and dynamic fluorescence emission from abies wood. Journal of Photochemistry and Photobiology A: Chemistry, v.78, n.3, p.275-279.

CASTELLAN, A. et al. (2007). Studies on fluorescence of cellulosic. Holzforschung, v.61, n.5, p 504-508.

CHEN, H. et al. (2010). Qualitative and quantitative analysis of wood samples by Fourier transform infrared spectroscopy and multivariate analysis. Carbohydrate Polymers, v.82, n. 15 , p.772-778.

CORREAA, A. C. (2010). Preparação de nanofibras de celulose a partir de fibras de curauá para desenvolvimento de nanocompósitos poliméricos com eva.Tese (Doutorado) - Centro de Ciências exatas e de Tecnologia, Universidade Federal de São Carlos São Carlos, 2010.

COSTA, M. L. Identificação, caracterização e gestão dos resíduos de madeira produzidos em obras de edificações em Salvador. 85p.Dissertação (Mestrado) - Escola Politécnica, Universidade Federal da Bahia, Salvador, 2007.

COSTA JR, E. S.; MANSUR, H. S. (2008). Preparação e caracterização de blenda de quitosana poli (álcool vinílico) reticuladas quimicamente com glutaraldeído para aplicação em engenharia de tecido. Química Nova, v.31, n.6, p.1460-1466.

COTTON INCORPORATED (2011).Disponível em: <http://www.cottoninc.com/CottonNonwoven-Technical-Guide/\#Table5>. Acesso em: 02 abr. 2011. 
DELBEN, J. R. J. et al. (2006). Pirólise à vácuo da aroeira. In:17 CBECIMat Congresso Brasileiro de Engenharia e Ciência dos Materiais, Foz do Iguaçu. Disponível em: <http://www.metallum.com.br/17cbecimat/resumos/17Cbecimat-202-047.pdf >. Acesso em: 15 ago. 2010.

DEMIRBAS, A. (2008). Biodiesel: a realistic fuel alternative for diesel engines. New York: Springer.

DEMIRBAS, A. (2009). Biorefineries: Current activities and future developments. Energy Conversion and Management, v. 50, n. 11, p. 2782-2801.

DEMIRBAS, A. (2010). Biorefineries: for biomass upgrading facilities upgrading facilities. New York: Springer.

DRAPCHO, C. M. et al. (2008). Biofuels Engineering Process Technology. New York: McGraw-Hill.

DONALDSON, L. A. (2001). Lignification and lignin topochemistry - an ultrastructural view. Phytochemistry, v.57, n.6, p.859-873.

DONALDSON, L. A.; LAUSBERG, M. J. F. (1998). Comparison of conventional transmitted light and confocal microscopy for measuring wood cell dimensions by image analysis. IAWA Jornal, v.19, N.3, p.321-336.

EARL, W. L.; VANDERHART, D. L. (1980). High resolution, magic angle sample spinning 13C NMR of solid cellulose I. Journal of the American Chemical Society, v.102, n.9, p. 3251-3252.

ESTEVAM-ALVES, R.; GUIMARAES, F. E. G. Caracterização da degradação enzimática do bagaço de cana através de microscopia e espectroscopia de fluorescência. In: XII Simpósio em Ciência e Engenharia de Materiais, 2009, São Carlos. Livro de Resumos do XII Simpósio em Ciência e Engenharia de Materiais. São Carlos: EESC, 2009.

FACETO, A. D. (2007). Simulação dos processos de migração e relexação energética em sistemas orgânicos $\pi$-conjugados emissores de luz. 122p. Dissertação (Mestrado). Instituto de Física de São Carlos, Universidade de São Paulo. São Carlos, 2007.

FASANELLA, C. C. (2008). Ação das enzimas ligninolíticas produzidas Aspergillus niger e Penicillium sp. em bagaço de cana-de-açúcar tratado quimicamente. 79p. Dissertação (Mestrado) - Escola Superior de Agricultura Luiz de Queiroz, Universidade de São Paulo, Piracicaba, 2008.

FERGEL, D.; WEGENER, G. (1984). Wood chemistry, ultrastructure, reactions. New York: Water de Gruyter.

FERNANDES, D. M. (2005). Estudo da estabilidade térmica de blendas de poli(álcool vinílico)lignina modificada. 151p. Dissertação (Mestrado) - Centro de Ciências Exatas, Departamento de Química, Universidade Estadual de Maringá, Maringá, 2005.

FERNANDES, M.; MUSSATTO, S.; ROBERTO, I. C. Influência do PH na precipitação da lignina obtida por polpação soda do bagaço de malte. In: Encontro Latino Americano 
de Iniciação Científica e VI Encontro Latino Americano de Pós Graduação, 2006, São José dos Campos. Disponível em: <http://www.inicepg.univap.br/cd/INIC_2006/inic/inic/07/INIC0000570ok.pdf>. Acesso em: 22 ago. 2010.

GAMBARATO, B. C. (2010). Estabelecimento e Validação de Modelos de Oxidação de Ligninas. 100p. Dissertação (Mestrado) - Escola de Engenharia de Lorena, Universidade de São Paulo, Lorena, 2010.

GARDRAT, C. et al (2004). Photochemical study of an o-ethyl dibenzodioxocin molecule as a model for the photodegradation of non-phenolic lignin units of lignocellulosics. Journal of Photochemistry and Photobiology A: Chemistry, v.167, n.2-3, p.111-120.

U.S. DEPARTMENT OF ENERGY GENOMIC SCIENCE PROGRAM. Biological and Environmental Research Information System (2010). Disponível em: < http://genomicscience.energy.gov.>. Acesso em: 2 fev. 2010.

GIERER, J.; PETTERSSON, I. (1977). Studies on the condensation of lignins in alkaline media. Part II: The formation of stilbene and arylcoumaran structures through neighbouring group participation reactions. Canadian Journal of Chemistry, v.55, n.4, p.593-599.

GILARDI, G.; ABIS, L; CASS, A. E. G.(1995). Carbon-13 CP/MAS solid-state NMR and FT-IR spectroscopy of wood cell wall biodegradation. Enzyme and Microbial Technology, v.17, n.3, p.268-275.

GOLDMAN, N. (2009). Methods for optimizing enzymatic hydrolysis of xylan to improve xylooligosaccharide yield. MMG 445 Basic Biotechnology e journal. v.5, n.1. p.31-36.

GOMES, F. A. (2009). Avaliação dos processos kraft convencional e Lo-Solids para madeira de Pinus taeda. 99p. Dissertação (Mestrado) - Escola Superior de Agricultura Luiz de Queiroz, Universidade de São Paulo, Piracicaba, 2009.

GREENTECHMEDIA (2010). Disponível em: http://www.greentechmedia.com/articles/read/denmark-makes-stab-for-biofuelgreatness/. Acesso em: 4 ago. 2010.

REDDY, K. O.; GUDURI, B. R.; RAJULU, A. V. (2009). Structural Characterization and Tensile Properties of Borassus Fruit Fibers. Journal of Applied Polymer Science, V.114, n.1, p.603-611.

GUPTA, R. B. and DEMIRBAS. A.(2010). Gasoline, Diesel, and Ethanol Biofuels from Grasses and Plants. São Paulo: Cambridge University Press.

GUTMAIS, G. (2008). Modulação do gene ugp e análise das alterações na composição dos carboidratos da parede celular primária e secundária de Nicotiana tabacum e Eucalyptus grandis. 142p. Tese (Doutorado) - Escola Superior de Agricultura "Luiz de Queiroz, Universidade de São Paulo, Piracicaba, 2008. 
HAFRÉN, J.et al. (2009). Fluorescence lifetime imaging microscopy study of wood fibers. Journal of Wood Science, v.55, n.3, p.236-239.

HALTTUNEN, M. et al. (2001) Study of Residual Lignin in Pulp by UV Resonance Raman Spectroscopy. Holzforschung, v. 55, n.4, p. 631-638.

HATFIED, G. R. et al (1987). Qualitative and quantitative analysis of solid lignin samples by carbon-13 nuclear magnetic resonance spectrometry. Anaytical Chemistry, v.59, n.1, p.172-179.

HEITNER, C.; DIMMEL, D.; SCHMIDT, J. (2010). Lignin and Lignans: Advances in Chemistry. CRC Pres Taylor \& Francis Goup (LCC), Estados Unidos, Florida, Boca Raton.

HOW STUFF WORKS A DISCOVERY COMPANY: SUGARCANE (2010). Disponível em: <http://science.howstuffworks.com/environmental/life/botany/sugarcaneinfo.htm>. Acesso em: 2 set. 2010.

HUANG, H. et al. (2011). Thermochemical liquefaction characteristics of microalgae in sub- and supercritical ethanol. Fuel Processing Technology, v.92, n.1, p. 147-153.

HUMAN GENOME PROJECT (2010). Disponível em: http://genomics.energy.gov/gallery/ Acesso em 18 ago 2010.

HSU, C.P. S.(1999). Infrared Spectroscopy: Handbook of Instrumental Techniques for Analytical Chemistry. Frank A. Setlle.

INTERNATIONAL ENERGY AGENCY (IEA). (2010). Paris: 2010 Key World Energy Statistics. Disponível em:

<http://www.iea.org/textbase/nppdf/free/2010/key_stats_2010.pdf>. Acesso em: 2 set. 2010.

INSTITUTE OF PHYSICAL CHEMISTRY. UVspectroscopy. (2009). Disponível em: < http://www.pci.uzh.ch/nonella/Anleitungen/UVspectroscopy.pdf>. Acesso em: 19 agos.2009

KAMIDE, K. (2005). Cellulose and Cellulose Derivatives Molecular Characterization and its Applications. 1 ed., Amsterdam: Elsevier

KITIN, P.; FUNADA, R.; SANO, Y.; OHTANI, J. (2000). Analysis by Confocal Microscopy of the Structure of Cambium in the Hardwood Kalopanax pictus. Annals of Botany, v.86, n.6, p.1109-1117.

LABAT, G. A. A.(2008). Estudo cinético da oxidação de ligninas obtidas da palha e do bagaço de cana e aplicações de lignina de bagaço em resinas à base de materiais naturais. 97p. Dissertação (Mestrado) - Escola de Engenharia de Lorena, Universidade de São Paulo, Lorena, 2008.

LAKOWICZ, J. R. (2006). Principles of fluorescence spectroscopy. 3 ed. New York: Springer. 
CLAXTON, N. S.; FELLERS, T. J.; DAVIDSON, M. W. (1979). Laser scanning confocal microscopy. Microscopy, v.1979, n. 21, p. 71-82

LEPPÄNEN, K. (2009). Structure of cellulose and microcrystalline cellulose from various wood species, cotton and flax studied by X-ray scattering. Cellulose, v.16, n.6, p.999-1015.

LIN, S. Y.; DENCE, C. W. (1992). Methods in Lignin Chemistry. Berlin: Springer Verlag.

LIN, Y. and TANAKA, S (2006). Ethanol fermentation from biomass resources: current state and prospects. Applied Microbiology and biotechnology, v. 69, n.6, p. 627-642.

LHONEUX, B. et al. (1988). Ultrastructural Characterization of Rice Husk Submitted to Different Pretreatments to Optimize its Fermentation. Biological Wastes, v.23, n.3, p.163-180.

LORENTZ, R. H. (2005). Seleção de isolados de paenibacillus spp com atividade enzimática e antimicrobiana. 84p. Dissertação (Mestrado) - Faculdade de Agronomia, Universidade Federal do Rio Grande do Sul, Porto Alegre, 2005.

MACHADO, A. E. H. et al. (2001). The use of fluorescent probes in the characterization of lignin: the distribution, by energy, of fluorophores in Eucalyptus grandis lignin. Journal of Photochemistry and Photobiology A: Chemistry, v.138, n.3, p.253-259.

MACHADO, A. E. H. et al (2006). Photophysics of dibenzodioxocins. Journal of Photochemistry and Photobiology A: Chemistry, v.180, n.1-2, p. 165-174.

MAIA, F. C. B. (2006). Correlação entre polarização da luminescência e orientação molecular em polímeros conjugados. 157p. Dissertação (Mestrado) - Instituto de Física de São Carlos, Universidade de São Paulo, São Carlos, 2006.

MARABEZI, K. (2009). Estudo sistemático das reações envolvidas na determinação dos teores de lignina e holocelulose em amostras de bagaço e palha de cana-deaçúcar. 142p. Dissertação (Mestrado) - Instituto de Química de São Carlos, Universidade de São Paulo, São Carlos, 2009.

MARLleTA, A. (2001). Propriedades Ópticas de Semicondutores Orgânicos à Base de Polímeros Emissores de Luz. p. 221. Tese (Doutorado) - Instituto de Física de São Carlos, Universidade de São Paulo, São Carlos, 2001.

MARTINS, L.F. (2005). Caracterização do complexo celulásico de Penicillium echinulatum. 121p. Dissertação (Mestrado) - Universidade Federal do Paraná, Curitiba, 2005 .

MARTins, M. A; MATTOSO, L. H. C.; PESSOA, J. D. C. (2009). Comportamento térmico e caracterização morfológica de fibras de mesocarpo e caroço do açaí (Euterpe oleracea Mart.). Revista Brasileira de Fruticultura, v.31, n.4.

MENEZES, C. R.; SILVA, I. S.; DURRANT, L. R. (2009). Bagaço de cana: fonte para produção de enzimas ligninocelulolíticas. Estudos Tecnológicos, v.5, n.1, p.68-78. 
MORENO-CASTILLA, C., Adsorption of organic molecules from aqueous solutions on carbon materials. Carbon. 42: 83, 2004.

MOSIER, N. et al. (2005). Features of promising technologies for pretreatment of lignocellulosic biomass. Bioresource Technology, v.96, n.6, p.673-686.

HAMDAOUI, O.; NAFFRECHOW, E. (2007) Modeling of adsorption isotherms of phenol and chlorofenols onto granular activated carbon. Part II. Models with more than two parameters. Journal Hazardous Materials. 147: 401,.

NASCIMENTO, R. A. A.; SILVA, F. T. (2002). Caracterização da lignina de bagaço de cana pré-tratado por explosão a vapor identificação dos compostos de degradação e reações envolvidas. In: $1^{\circ}$ SEMINÁRIO DE PÓS-GRADUAÇÃO e $6^{\circ}$ SEMINÁRIO DE INICIAÇÃO CIENTÍFICA, 2002, Lorena. Disponível em: <http://www.eel.usp.br/sevap/Sevap.PDF>. Acesso em: 22 set. 2010.

OGEDA, T. L.; PETRI. D. F. S. (2010). Hidrólise enzimática de biomassa. Química Nova, v.33, n.7, p.1549-1558.

OMESTEAD, J. A. et al. (1995). Fluorescence spectroscopy of mechanical pulps III: effect of chlorite delignification. Canadian Journal of Chemistry. v.73, n.11, p.19551959.

PÄÄKKÖ, M. et al. (2007). Enzymatic hydrolisis combined with mechanical shering and high-pressure homogenization for nanoscale cellulose fibrils and stroong gels. Biomacromolecules, v.8, n.6, p. 1934-1941.

PANDEY, K. K.; UPRETI, N. K.; SRINIVASAN, V. V. (1998). A fluorescence spectroscopic study on wood. Wood Science and Technology, v.32, n.2, p.309-315.

PANDEY, K. K. (1999). A Study of Chemical Structure of Soft and Hardwood and Wood Polymers by FTIR Spectroscopy. Journal of Applied Polymer Science, v.71, n.12, p.1969-1975.

PASTORE T. C. M. (2004). Estudos do efeito da radiação ultravioleta em madeiras por espectroscopias Raman (FT-Raman), de reflectância difusa no infravermelho (DRIFT) e no vísivel (CIE-L*a*b*). 117p. Tese (Doutorado) - Instituto de Química, Universidade de Brasília, Brasília, 2004.

RADOTIC, K.; et al. (2006). Component analysis of the fluorescence spectra of a lignin model compound. Journal of Photochemistry and Photobiology B: Biology, v.83, n.1, p.1-10.

RAMIRES, E. C.(2010) Biocompósitos a partir de matrizes poliméricas baseadas em lignina, tanino e gl. 262p. Tese (Doutorado) - Instituto de Química de São Carlos, Universidade de São Paulo, São Carlos, 2010.

REDDY, K. O.; GUDURI, B. R.; RAJULU, A. V. (2009). Structural Characterization and Tensile Properties of Borassus Fruit Fibers. Journal of Applied Polymer Science, v.114, n.1, p.603-611. 
RIO, J. D. C. et al.(2005). Determining the influence of eucalypt lignin composition in paper pulp yield using Py-GC/MS. Journal of Analytical and Applied Pyrolysis, v.74, p.110-115.

SANCHEZ, E. M. S. et al. (2010). Compósito de Resina de Poliéster Insaturado com Bagaço de Cana-de-Açúcar: Influência do Tratamento das Fibras nas Propriedades. Polímeros, v.20, n.3, p.194-200.

SANTOS. H. F. (2001). Análise conformacional de modelos de lignina. Química Nova, v.24, n.4, p.480-490.

SELEGHIM JR, P. ; POLIKARPOV, I. (2009). Desafios para transformar conceitos em realidade. Scientific American Brasil, n. 87, p.32 - 37.

SHEN, D.K. et al. (2010). The pyrolytic degradation of wood-derived lignin from pulping process. Bioresource Technology. v.101, n.15, p. 6136-6146

SILVA, S. S. et al. (1998). Extração e caracterização de xilanas de sabugos de milho. Polímeros. Ciência e Tecnologia, v.8, n.2.

SILVA, V. F. N.(2009). Estudos de pré-tratamento e sacarificação enzimática de resíduos agroindustriais como etapas no processo de obtenção de etanol celulósico. 116p. Dissertação (Mestrado) - Escola de Engenharia de Lorena, Universidade de São Paulo, Lorena, 2009.

SILVERSTEIN, R. M.; WEBSTER, F. X.; KIEMELE, O. J. Identificação espectrométrica de compostos orgânicos. $7^{\mathrm{a}}$ ed. Livros Técnicos e Científicos (LTC). Rio de Janeiro, 2007.

SINGHANIA, R. R. et al.(2008). Handbook of Plant-Based Biofuels. New York: Ashok Pandey.

SKOOG, D. A.; HOLleR, F. J.; CROUCH, S. R. (2009). Princípios de análise instrumental. 6 ed .Porto Alegre: Bookman.

STACEY, W. M. (2010). Fusion: an introduction to the physics and tecnology of magnetic confinement fusion. 2 ed. Weinheim: WILEY-VCH.

STICKLEN, M. (2008). Plant genetic engineering for biofuel production: towards affordable cellulosic ethanol. Nature reviews genetics. v.9, p. 433-443.

STOCKERT, A. R. V. (2008). Etanol - aspectos históricos, tecnológicos e ambientais. Monografia (Graduação), Universidade Federal de Santa Catarina, Florianópolis, 2008.

SUN, Y.; CHENG, J. (2002). Hydrolysis of lignocellulosic materials for ethanol production: a review. Bioresource Technology, v. 83, n.1, p.1-11.

TSUTAE, F. M. Processos ópticos e interação entre nanopartículas e sistemas moleculares. Dissertação apresentada ao Programa de Pós-graduação em Física do Instituto de Física de São Carlos da Universidade de São Paulo, para obtenção do título de Mestre em Ciências. Área de Concentração: Física Aplicada. São Carlos, 2010. 
TYLLI et al (1995). The effect of photoirradiation on high-yield pulps: spectroscopy and kinetics. Journal of Photochemistry and Photobiology A: Chemistry v. 87, n.2, p.181191.

TYLLI, H. FORSSKAHL, I.; OLKKONEN, C. A fluorescence spectroscopic study of chemically and photochemically treated high-yield pulps. Journal of Photochemistry and Photobiology A: Chemistry. 1992; 67(1):117-131

XU, F. et al. (2006). Comparative study of anatomy and lignin distribution in normal and tension wood of Salix gordejecii. Wood Sci Technol, v.40, n.5, p.358-370.

ZHAO, J. et al. (2002). Xylanase pretreatment leads to enhanced soda pulping of wheat straw. Enzyme and Microbial Technology, v.30, n.6, p.734-740. 


\section{Apêndice A - Medidas de T2 por níveis de saturação em fibras de eucaliptos}

(a)

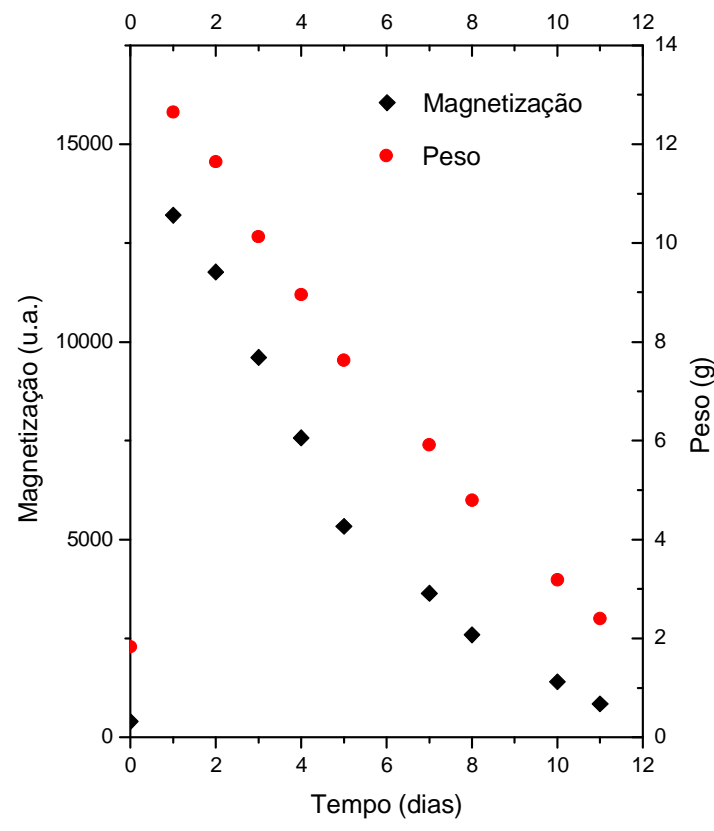

(b)

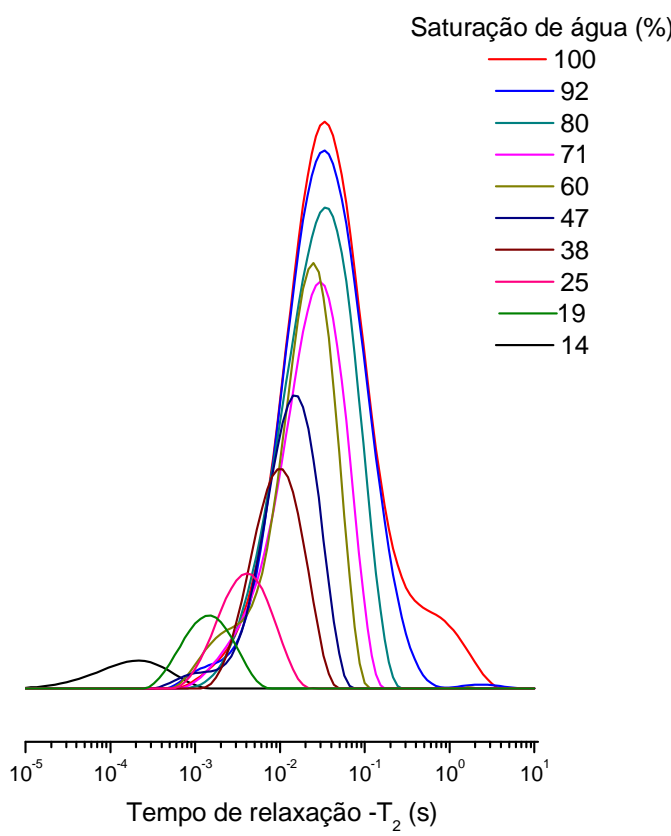

Figura 1A - (a) variação do peso por evaporação em relação ao tempo de repouso da amostra de fibra de eucalipto não tratada com ácido e/ou enzima (FENT); (b) Distribuição dos tempos de relaxação transversal para saturações diferentes de fibras de eucalipto não tratada com ácido e/ou enzima (FENT).

(a)

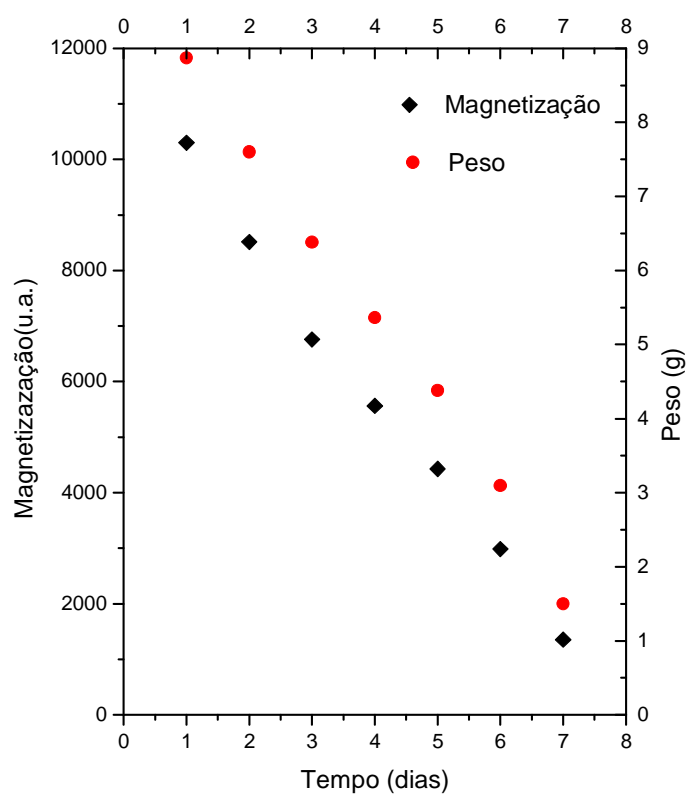

(b)

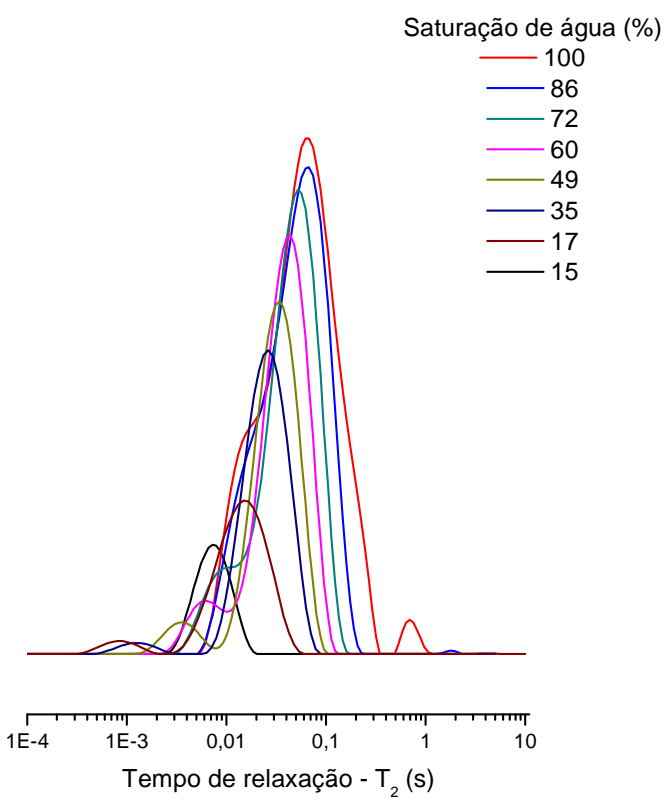

Figura 2A - (a) variação do peso por evaporação em relação ao tempo de repouso da amostra de fibra de eucalipto tratada com ácido e enzima (FETEA); (b) Distribuição dos tempos de relaxação transversal para saturações diferentes de fibras de eucalipto tratada com ácido e enzima (FETAE). 